ASSOCIAÇÃO DE POLITÉCNICOS DO NORTE (APNOR)

INSTITUTO POLITÉCNICO DE BRAGANÇA

Increasing the economic sustainability of the company JSC "Novoazovskoe"

\title{
Kopeikina Victoria
}

Final Dissertation submitted to Instituto Politécnico de Bragança

To obtain the Master Degree in Management, Specialisation in Business

Management

Supervisors:

Paula Odete Fernandes

Olga Kosenchuk 


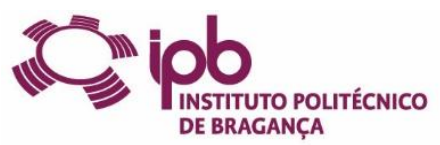

\section{ASSOCIAÇÃO DE POLITÉCNICOS DO NORTE (APNOR) \\ INSTITUTO POLITÉCNICO DE BRAGANÇA}

\section{Increasing the economic sustainability of the company JSC \\ "Novoazovskoe"}

Kopeikina Victoria

Supervisors:

Paula Odete Fernandes

Olga Kosenchuk 


\section{Abstract}

Increasing of economic sustainability of an enterprise is one of the most important problems in current global economic and political conditions. For agricultural companies this issue is important in higher grade. One of the ways of economic sustainability increasing is to improve the quality of harvested feed for animals, namely - haylage. In this Master thesis it was considered the meaning of "Economic sustainability" and ways of its increasing. Also in theoretical part it was presented main features of economic sustainability in agricultural enterprises and ways of its increasing. As one of the ways of economic sustainability increasing was considered the modifying of harvesting system. As the considered enterprise it was used Joint Stock Company "Novoazovskoe" of Azovsky German National district of Omsk region of Russian Federation. According to the topic of Master Thesis it was implemented the general analysis of legal, managerial, financial and productive information of considered enterprise. To identify the most prospective ways of increasing an economic sustainability in terms of harvesting system, it was implemented the analysis of existing haylage harvesting system. In final chapter of Master thesis, it was proposed the modern system of haylage harvesting, offered the purchasing of required agricultural machineries for implementing of new system, and presented the economic results received after implementation of new haylage harvesting system.

The main results show that after implementation of new haylage harvesting system the total volume of good haylage increased up to $88 \%$ of total remained mass and $93 \%$ of initial harvested mass. Accumulated gross profit for 5 years received from realization of the surplus of a good haylage was more than 29 million rubles.

Keywords: Economic sustainability, agricultural companies, haylage harvesting process, high-quality haylage, harvesting agricultural machineries. 


\section{Resumo}

O aumento da sustentabilidade económica de uma empresa é um dos problemas mais importantes nas atuais condições económicas e políticas globais. Para as empresas agrícolas, esta questão torna-se ainda mais importante. Uma das formas de aumento da sustentabilidade económica assenta em melhorar a qualidade dos alimentos colhidos para animais, nomeadamente - o cultivo de animais. No presente trabalho foi considerado o significado de "sustentabilidade económica" e algumas formas de aumentar a mesma. Também na parte teórica foram apresentadas as principais características da sustentabilidade económica nas empresas agrícolas e formas de aumentar. Como uma das formas de aumento da sustentabilidade econômica será considerada a modificação do sistema de colheita. Como a empresa considerada será usada Joint Stock Company "Novoazovskoe" do distrito nacional alemão Azovsky da região de Omsk da Federação Russa. De acordo com o tema da dissertação de Mestrado foi implementada a análise geral de informações legais, de gestão, financeiras e produtivas da empresa considerada. Para identificar as formas mais potenciais de aumentar a sustentabilidade económica em termos de sistema, foi implementada a análise do sistema existente de colheita de palha. No capítulo final da disertação de mestrado será proposto o sistema moderno de colheita de palha, ofereceu a compra de máquinas agrícolas necessárias para implantação do novo sistema e apresentou os resultados económicos obtidos após a implantação do novo sistema de colheita de palha.

Os resultados permitem concluir que, após a implementação do novo sistema de colheita de feno, o volume total aumentou até $88 \%$ do total e $93 \%$ da colheita inicial. O lucro bruto acumulado por 5 anos recebido da realização do superávit de um bom stock foi mais de 29 milhões de rublos.

Palavras-chave: Sustentabilidade económica, empresas agropecuárias, processo de colheita de feno, feno de alta qualidade, colheita com máquinas agrícolas. 


\section{Аннотация}

Повышения экономической устойчивости предприятия является одной из наиболее важных проблем в глобальных политической и экономических условиях. На сельскохозяйственных предприятиях эти условия отражаются значительно сильнее. Одним из путей повышения экономической устойчивости компании является повышение качества заготавливаемых кормов, а именно сенажа. В данной Магистерской работе будет рассмотрено понятие «Экономическая устойчивость» и пути её повышения. В теоретической части данной работы так же будут представлены основные характеристики экономической устойчивости сельскохозяйственных предприятий, а также приведены пути её повышения. В качестве одного из путей повышения экономической устойчивости будет рассмотрено изменения действующей системы кормозаготовки. В качестве рассматриваемого предприятия будет использовано Акционерное Общество «Новоазовское» Азовского Немецкого Национального Района Омской области Российской Федерации. В соответствии с основной темой Магистерской работы будет проведён анализ юридической, управленческой, финансовой и производственной информации рассматриваемого предприятия. Для определения наиболее перспективных путей повышения экономической устойчивости в сфере кормозаготовки, будет проведён анализ действующей системы заготовки сенажа на корм. В заключительной части Магистерской работы будет предложена современная система заготовки сенажа на корм, предложено приобретение необходимой сельскохозяйственной техники для внедрения новой системы, и представлены экономические результаты, полученный от внедрения новой системы заготовки сенажа на корм.

Основные результаты, полученные от реализации новой системы заготовки сенажа на корм, показывают, что количество качественного сенажа возросло до $88 \%$ от общего оставшегося сенажа и до 93\% от первоначально заготовленной массы. Валовая прибыль накопленным итогом за 5 лет реализации проекта и, как результат, продажи излишков качественного сенажа, составит более 29 миллионов рублей.

Ключевые слова: Экономическая устойчивость, сельскохозяйственные компании, заготовка сенажа на корм, высококачественный сенаж, кормозаготовительные машины. 


\section{Acknowledgements}

First of all, I would like to express my gratitude to my family! Their hope and support were really important for me during whole studying process.

Further, I would like to express my gratitude to my home University - Omsk State Agrarian University - for offered opportunity to be involved in the Program of International Credit Mobility in Portugal. Many thanks to the President of OmSAU, Doctor of Economics, Shumakova Oxana, to the Vice-president of OmSAU, Doctor of Economics, Aleschenko Vitaly, to my Russian Supervisor the Dean of Zootechnician Faculty, $\mathrm{PhD}$ in Agricultural Science, Kosenchuk Olga, to the Faculty of Economic Science of OmSAU, and to the Department of International Affairs of OmSAU.

My gratitude is also for the host university - Polytechnic Institute of Braganca (IPB) - for such a great opportunity to be enrolled for studying in there. Many thanks to the President of IPB, João Teixeira, to the Vice-president of IPB, Luis Pais, to my Portuguese Supervisor and Responsible of the Master Programme in Management, $\mathrm{PhD}$ in Economics and Management, Paula Fernandes, and to the Department of International Affairs of IPB, especially to Joana Aguiar.

My greater thanks is for the Sponsors of International Credit Mobility Program in Portugal in 20162017.

Also, I would like to forward many thanks to the management of JSC "Novoazovskoe" for provided data and information, and for the hope in my future projects and researches! 


\section{Abreviation and Acronyms}

JSC - Joint Stock Company

CCEAT - Common Classificatory of Economic Activity Types

EUR - Euros

h.p. - horse power

ha - hectare

IPB - Politechnic Institute of Bragança

$\mathrm{kg}$ - kilogram

$\mathrm{kWt}$ - kilowatt

mln - million(s)

$\mathrm{mm}$ - millimeter

OmSAU - Omsk State Agrarian University

PCV - Price-Cost-Volume

PSRN - Primary State Registration Number

rot./min. - rotation per minute

$t-$ ton

TIN - Tax Individual Number 


\section{Content}

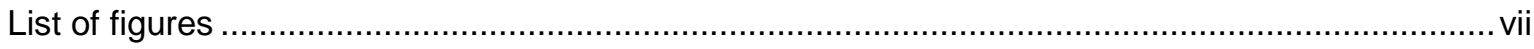

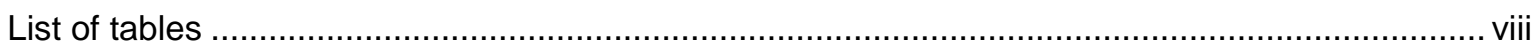

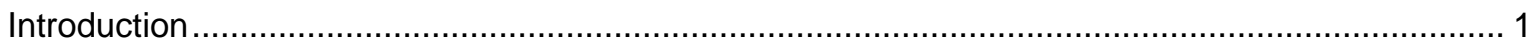

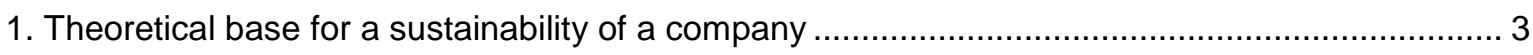

1.1. Meanings of an economic sustainability and competitiveness of a company ........................... 3

1.2. Types of economic sustainability. Factors of sustainable development of a company............... 6

1.3. Features of increasing the sustainability of a company in agribusiness industry ..................... 8

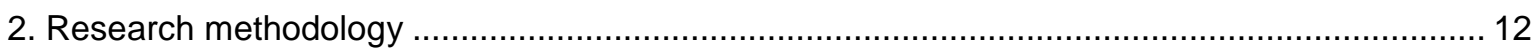

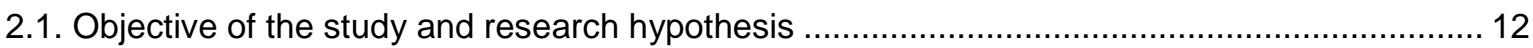

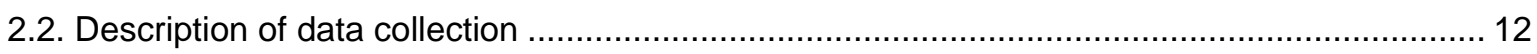

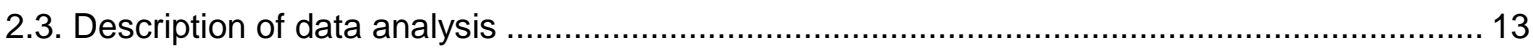

3. Organizational and economical evaluation of JSC "Novoazovskoe" ........................................ 15

3.1. Legal status and management system of JSC "Novoazovskoe" ........................................ 15

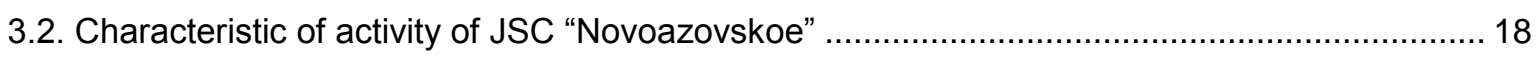

3.3. Evaluation of financial-economic status of JSC "Novoazovskoe" ........................................... 32

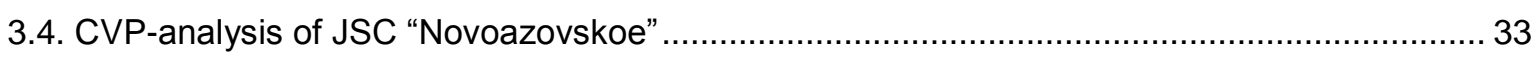

4. Increasing the economic sustainability of JSC "Novoazovskoe"............................................. 40

4.1. Description of existing harvesting system and identifying the reasons for managerial decisions

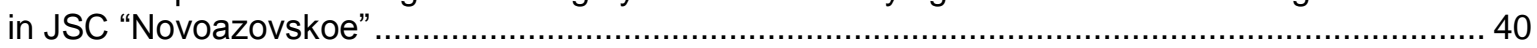

4.2. Rationale of managerial decision and description of proposed harvesting system .................. 43

4.3. Economic evaluation of implemented measures for increasing of economic sustainability in

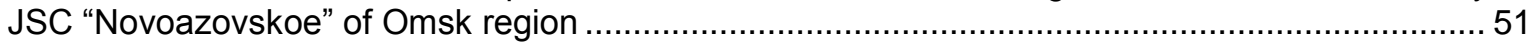

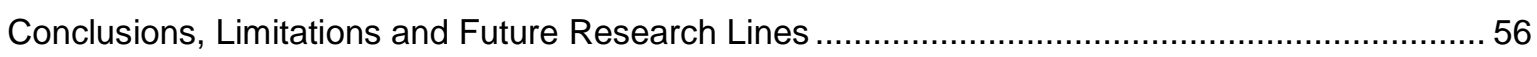

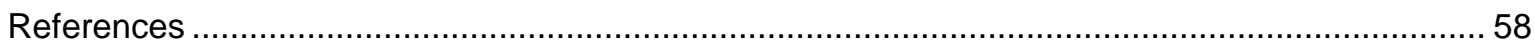




\section{List of figures}

Figure 1. Management of economic sustainability on the enterprise ......................................... 5

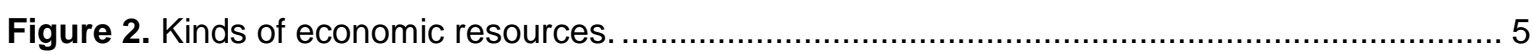

Figure 3. Factors of economic sustainability of agricultural production. .................................... 10

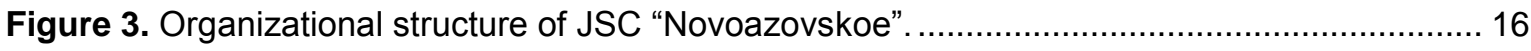

Figure 4. First managerial level of JSC "Novoazovskoe"......................................................... 16

Figure 5. Scheme of the second managerial level of JSC "Novoazovskoe"................................. 17

Figure 6. Dynamic of balance sheet's total results changing. …............................................. 21

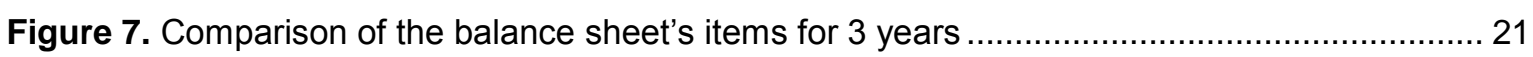

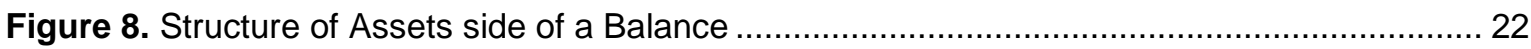

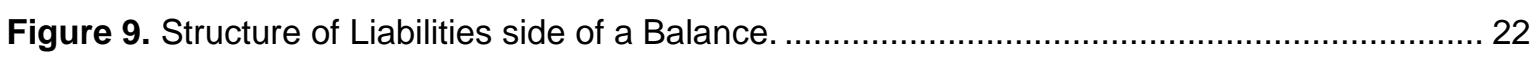

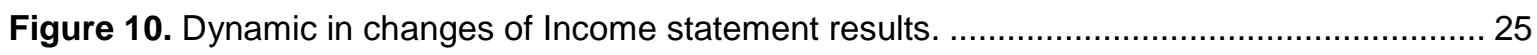

Figure 11. Result of vertical and horizontal analyses of lands' structure. ..................................... 26

Figure 12. Financial results and breakeven point of crop production, in thousands rubles. ............ 35

Figure 13. Production results and breakeven point of crop production, in centners..................... 35

Figure 14. Financial results and breakeven point of milk production, in thousands rubles............. 37

Figure 15. Production results and breakeven point of milk production, in centners........................ 37

Figure 16. Negative results of obsolete machineries use in haylage harvesting process. ............. 41

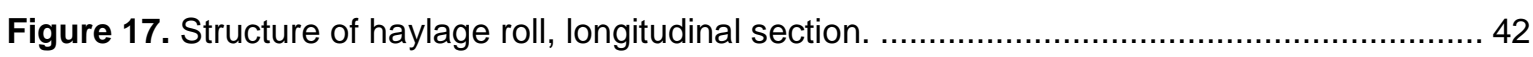

Figure 18. Scheme of reasons and results of low quality harvesting feed (haylage)....................... 43

Figure 19. Reasons of reduction of quality and quantity of a haylage, in \%................................. 44

Figure 20. Effect after implementation of new agriculture machineries for haylage

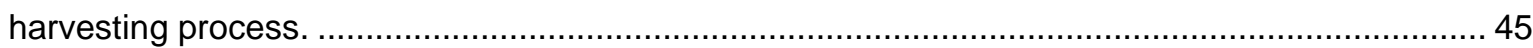

Figure 21. Difference between implemented scheme of drying and existing one.......................... 47

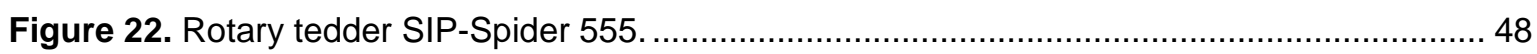

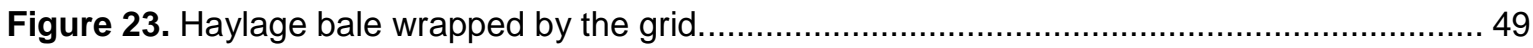

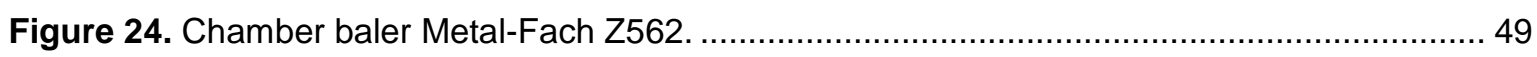

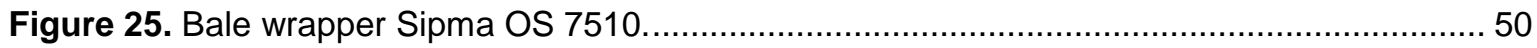

Figure 26. Front loader PSN-1 with bale grabber ZR-1 ...................................................... 51 


\section{List of tables}

Table 1. Approaches to the definition "economic sustainability of enterprises".............................. 4

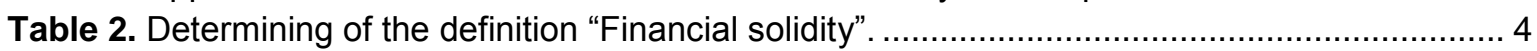

Table 3. Factors of sustainable development of enterprise ..................................................... 7

Table 4. Accordance of indicators of enterprise's efficiency and factors of sustainable

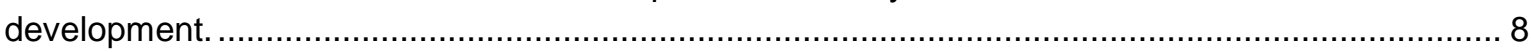

Table 5. Differentiation of economic sustainability of enterprise by the types of influence. ............. 9

Table 6. Balance sheet of JSC "Novoazovskoe" for 2013-2015, vertical analysis. ......................... 19

Table 7. Year-to-year horizontal analysis of JSC "Novoazovskoe" Balance sheets. ....................... 20

Table 8. Income statement of JSC "Novoazovskoe" for 2013-2015, vertical analysis. ................... 23

Table 9. Year-to-year horizontal analysis of Income Statement of JSC "Novoazovskoe"............... 24

Table 10. Composition and structure of lands of JSC "Novoazovskoe" for 2013-2015.................. 25

Table 11. Composition and structure of means of production in JSC "Novoazovskoe"

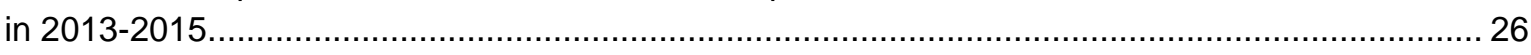

Table 12. Number of animals employed and their cost in JSC "Novoazovskoe" for 2013-2015 .... 27

Table 13. Average number of employees in JSC "Novoazovskoe" for 2013-2015. …................... 28

Table 14. Composition and structure of sold plant production in JSC "Novoazovskoe"

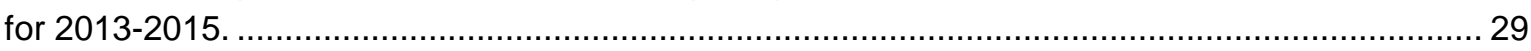

Table 15. Composition of livestock production in JSC "Novoazovskoe" for 2013-2015................. 30

Table 16. Production results of specified kind of productions in JSC "Novoazovskoe"

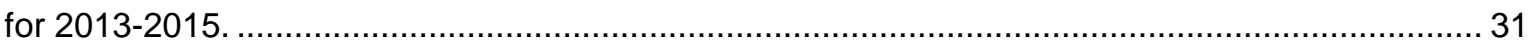

Table 17. General financial ratios for $2013-2015$, in thousand rubles........................................ 32

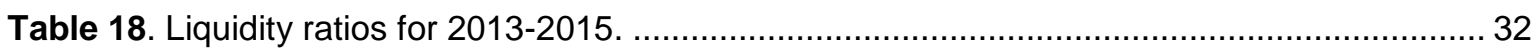

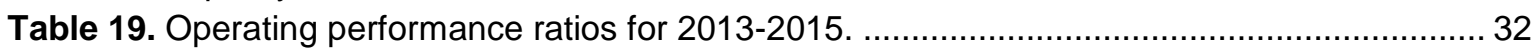

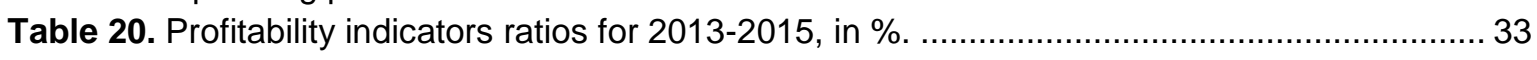

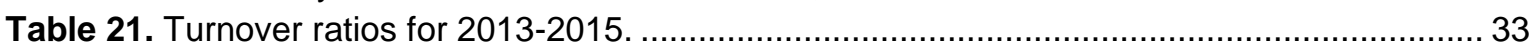

Table 22. Results of grain production in JSC "Novoazovskoe" for 2013-2015............................. 34

Table 23. Results of breakeven point in crop production in JSC "Novoazovskoe"

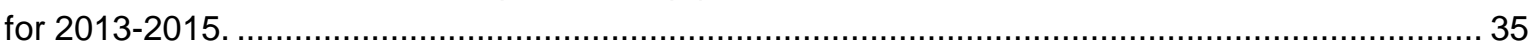

Table 24. Results of milk production in JSC "Novoazovskoe" for 2013-2015. .............................. 36

Table 25. Results of breakeven point in milk production in JSC "Novoazovskoe"

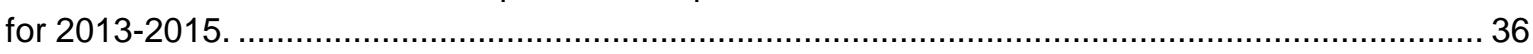

Table 26. Financial strength indicator for crop and milk production in JSC "Novoazovskoe"

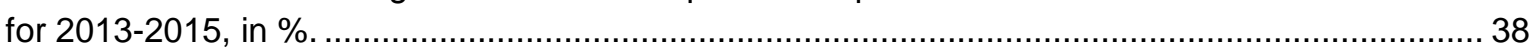

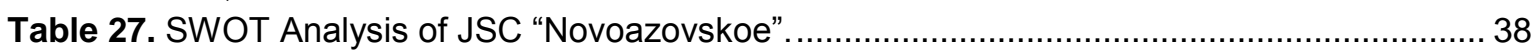

Table 28. Cost of repairs and idle time during haylage harvesting process.................................. 41

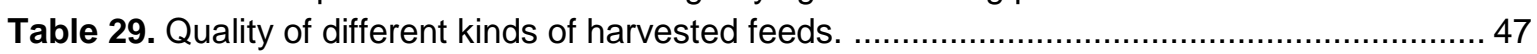

Table 30. Comparison of technical characteristics of rotary tedders of various marks. .................. 48

Table 31. Comparison of technical characteristics of chamber baler of various marks. ................. 49

Table 32. Comparison of technical characteristics of bale wrappers of various marks.................. 50

Table 33. Production and consumption of a haylage in JSC "Novoazovskoe" in 2013-2015. ........ 52

Table 34. Volume of lost haylage during harvesting, storage and use for 2013-2015 .................. 52

Table 35. Proposed results after implementation of new harvesting system in 2013-2015........... 53

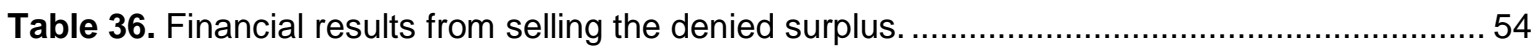

Table 37. Initial expenditures and financial results of new harvesting system implementation. ..... 54 


\section{Introduction}

The problem of economic sustainability of enterprise is a very strong problem. The statement of agricultural enterprises in current conditions is quite unsteady, high risk, low profitability and other factors lead to rethink the main principles of economic sustainability and activity of enterprise. As economic sustainability of enterprise are the balanced conditions of economic resources, which ensuring stable generating of profit and normal conditions for expanded production, persistent growth in long-term prospective with consideration of main external factors.

The relevance of research about increasing of economic sustainability of agricultural enterprise is conditioned by the fact, that development and economically efficient activity of enterprise is in direct relation from the ability of implement the most modern agricultural technologies. Nowadays, the leading enterprise in this branch, both domestic and international, realized the importance of implementing the latest scientific achievements in production. Implementing the latest technologies, these companies optimize the expenditures on resources, finances and time. This leads to the opportunities for intensification of production, and, consequently, improving products quality, generating additional profit, and strengthening the company's position on the market.

In this regards the main objective of this Master thesis is searching of theoretical statements and validation measures of economic sustainability increasing of JSC "Novoazovskoe".

Tasks of Master thesis:

1) Consider the main problem and ways of increasing of economic sustainability of enterprise generally, and agricultural enterprise particularly;

2) Analyse the activity of JSC "Novoazovskoe";

3) Analyse the ways of increasing the economic sustainability of enterprise;

4) Justify measures of increasing of economic sustainability of JSC "Novoazovskoe" by implementing of modern system of haylage harvesting.

The object of observation - JSC "Novoazovskoe" of Azovsky German National district of Omsk region of Russian Federation.

Object of research is economic sustainability of JSC "Novoazovskoe". Subject of research implementation of modern system of haylage harvesting as the way of increasing of economic sustainability of enterprise.

In first chapter of Master thesis will be considered various definitions of "Economic sustainability" and "Economic solidity", and will be named specific features of increasing of economic sustainability of agricultural enterprise.

In second chapter will be considered the Methodology of making all of the researches and analysis of data and information collected, related with the main subject of Master thesis. All of the approaches of analysis will be used in third chapter. 
In third chapter will be made analyses of legal status of enterprise, its managerial structure, production activity, and financial results of activity for 2013 to 2015 years. Also, will be implemented the analysis of potential ways of increasing economic sustainability.

In fourth part will be presented the ways of increasing of economic sustainability of JSC "Novoazovskoe" by using the modern haylage harvesting system. Also, will be calculated the total financial and production results obtained after implementation of new haylage harvesting system.

During making this Master thesis will be used the bookkeeping and managerial statement of JSC "Novoazovskoe" for 2013-2015, open internet sources, related with financial, statistical, managerial and other information; libraries of OmSAU, IPB and international bases and libraries; scientific and specialized online and regular journals of both countries, as well as international ones; data from governmental portals and sources related with the theme of Master thesis; information from the companies-producers of agricultural machineries, required for modern haylage harvesting process. 


\section{Theoretical base for a sustainability of a company}

\subsection{Meanings of an economic sustainability and competitiveness of a company}

Nowadays because of impaction of external environment the enterprises become more complicated systems. There is going the process of integration of enterprises by the mergers and acquisitions. It happens on the voluntarily, or forcibly. All of that gets the new requirements to the methods of managing of the enterprises in current conditions. Because of that one of the most important issues for any enterprise is the ensuring its own economic sustainability in short-term and long-term prospective (Anisimov, 2006).

First term "economic sustainability" appeared because of consideration of the problem of scarcity of recourses, which became the result of global energy crisis of 1973 and 1979. Then, this flow of economic thought became into separate discipline called "ecosestate", which means the economic sustainability of a country. It started to considered the issues of sustainable economic development on the level of country and region.

However, recently it becomes increasingly clear that economic sustainability development of a country and region is achieved only with economic sustainability of all structural elements such as industries, enterprises and organizations. Economic sustainability of each individual enterprise let to all economic system of a country not only save the potential, but also to ensure its quality rise and entrance to international markets with new competitive goods (Laibert, 2011).

Nowadays there is a multiplicity of points of view of different authors for the concept "economic sustainability of an enterprise". Some of them are presented in the Table 1. 
Table 1. Approaches to the definition "economic sustainability of enterprises".

\begin{tabular}{ll}
\hline \multicolumn{1}{c}{ Authors } & \multicolumn{1}{c}{ Definition } \\
\hline $\begin{array}{l}\text { Badrov O. } \\
\text { Timiryasov V. }\end{array}$ & $\begin{array}{l}\text { The economic sustainability enterprises are such enterprises, which in terms of } \\
\text { uncertainty, instability of the market, in the greatest grade ensure the organizing of } \\
\text { modern scientific and production activity (Bodrov, 2008). }\end{array}$ \\
\hline Kamaev V. & Economic sustainability - it's a regular receiving of revenues (Kamaev, 2008). \\
\hline Bryantsev I. & $\begin{array}{l}\text { Economic sustainability - is the state of enterprise, in which all related socio- } \\
\text { economic parameters keep the initial balance and are in given borders with impact } \\
\text { of internal and external environment (Bryantseva, 2007). }\end{array}$ \\
\hline Zakharchenko V. & $\begin{array}{l}\text { Economic sustainability - it's the complex of features of organizational. Innovative, } \\
\text { logistic, production, financial and credit activity with consideration of its mutual } \\
\text { influence and interaction (Zakharchenko, 2009). }\end{array}$ \\
\hline $\begin{array}{l}\text { Omelchenko I. } \\
\text { Borisova E. }\end{array}$ & $\begin{array}{l}\text { Economic sustainability - it's a financial and economic sustainability (solidity), } \\
\text { namely: the ability of production enterprise keep its financial solidity on } \\
\text { permanently changing market by upgrading and target development of its } \\
\text { production, technical, and organizational structure by logistic oriented methods of } \\
\text { management (Omelchenko, 2009). }\end{array}$ \\
\hline $\begin{array}{l}\text { Schaltegger, S., } \\
\text { Lüdeke-Freund, F., }\end{array}$ & $\begin{array}{l}\text { Corporate sustainability - strategies are of crucial importance to sustainable } \\
\text { development but also for successfully directing a company through sustainability } \\
\text { Hansen, E. G. }\end{array}$ \\
$\begin{array}{l}\text { related social, legal, political and economic requirements under conditions of } \\
\text { market competition (Schaltegger, Luedeke-Freund, \& Hansen, 2012). }\end{array}$
\end{tabular}

Source: Author's own elaboration.

It is thought that economic sustainability means not only the keeping of positive trends of all related indicators, but also includes development, which appears in economic growth, that is a trend of positive changes of aggregate indicators of development for determined period of time (usually for a year). For characteristic of economic growth are used both common and particular indicators. The most interesting and important indicators among all, is the financial solidity.

Need to consider the definitions of the financial solidity from the points of view of different authors, presented in the Table 2.

Table 2. Determining of the definition "Financial solidity".

\begin{tabular}{cl}
\hline Author & Financial solidity - the solidity of financial relationships and links of an object or \\
& a system (Golobokova, 2008). \\
\hline Golobokova G. & $\begin{array}{l}\text { Stable financial position of the firm - is the characteristic of its financial } \\
\text { competitiveness, usage of financial resources and capital, fulfillment of } \\
\text { commitments over the state and other enterprises (Bakanova, 2008). }\end{array}$ \\
\hline Kovaleva A. & Financial solidity of a company and its sustainability depend on the results of its \\
& production, commercial and financial activity. Results show the solidity of an \\
& enterprise, and, eventually, help its development (Kovalev, 2010). \\
\hline Moles P., & Financial solidity - is effectively a promise to repay based on the current and \\
Terry N. & future cash flow or earnings of the issuer, or a third-party guarantor (Moles \& \\
& Terry, 1997)
\end{tabular}

Source: Author's own elaboration. 
Comparison of definitions "economic sustainability" and "financial solidity" is showing to us that most of authors consolidate these definitions. Rationale for this is the statement that enterprise's position on the market firstly depends on the presence and directions of financial resources usage. Estimation of financial position of an enterprise can help to determine the "bottle-necks" in entrepreneurial activity, and also to find the solution for avoidance of adverse trends of company's development. Thus, financial solidity permits objectively to estimate the tactic of management (Lakshina \& Chekmareva, 2009). Consider the mechanism of management of economic sustainability on the enterprise, presented on the Figure 1.

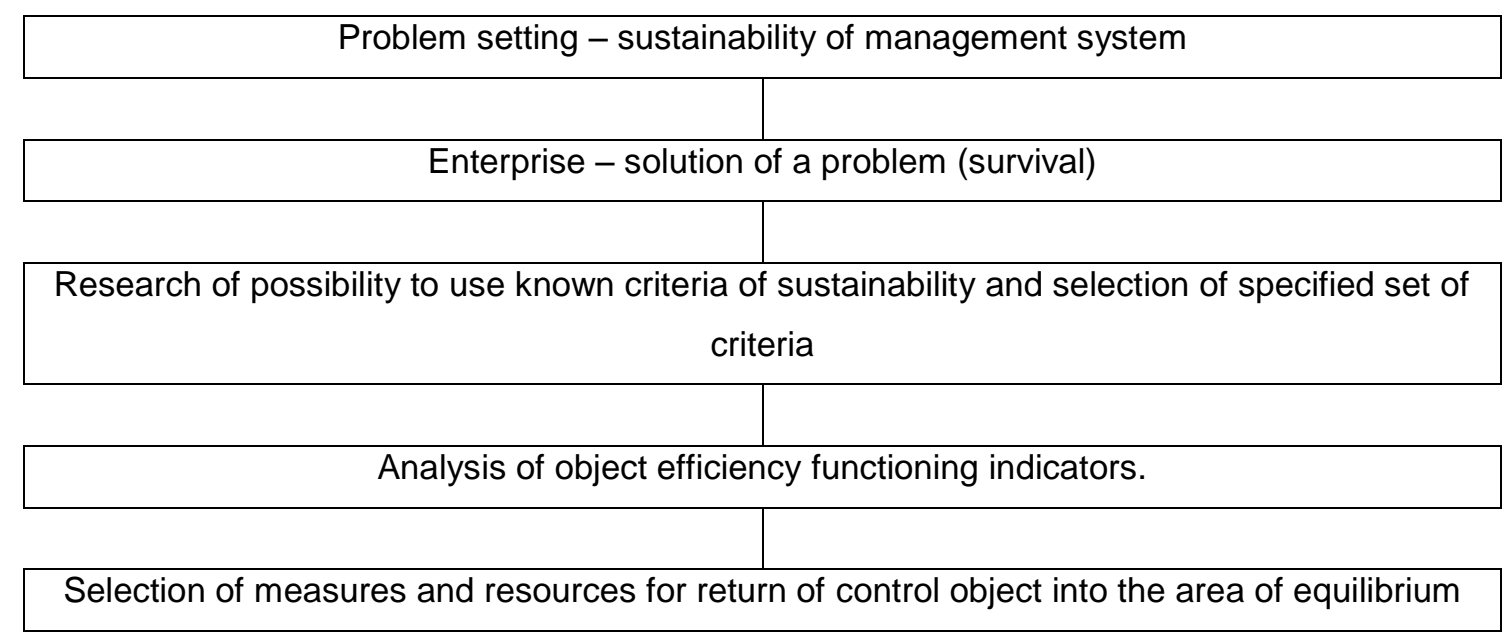

Figure 1. Management of economic sustainability on the enterprise.

Source: (Anisimov, 2006)

Sustainable business of an enterprise depends on the internal possibilities to effectively use all of available economic resources. Under the economic resources are referred all natural, human, and man-made resources, which are used for the production of goods and services. All of them are on the Figure 2.

\begin{tabular}{|c|c|c|c|c|c|}
\hline \multicolumn{6}{|c|}{ Economic resources } \\
\hline $\begin{array}{c}\text { Natural } \\
\text { resources }\end{array}$ & Labor & Capital & Entrepreneurial abilities & $\begin{array}{c}\text { Knowledge } \\
\text { (information) }\end{array}$ \\
\hline
\end{tabular}

Figure 2. Kinds of economic resources.

Source: (Koryakov, 2012)

Under economic resources are referred all kinds of resources used in the process of goods and services production. Basically, it is the goods, which are used for other goods production (Bulatov, 2007).

Thus, the definition of economic sustainability can be formulated as the equilibrium balanced state of economic resources, which ensure stable profitability and normal conditions for sustainable 
economic growth in long-term prospective with consideration of the most important internal and external factors.

\subsection{Types of economic sustainability. Factors of sustainable development of a company}

Many definitions of "economic sustainability" in relation with enterprises have the characteristics (parameters) of sustainability. That is, on the level of companies it is possible to distinguish various components of sustainability: financial, technological, organizational, commercial, and others. Consider some of them more in details. (Golovko, 2013)

Production and technical sustainability of an enterprise determines by its solidity of production cycle, coordination of resource and material provision.

Commercial sustainability - determines by the level of economic activity, reliability of economic ties, competitive potential of a company, its share on the market.

Organizational sustainability means the stable of internal organizational structure, relation and efficiency of ties between departments and offices of an enterprise, efficiency of their common operations.

Innovation sustainability characterizes the ability of an enterprise to implement new technologies and methods of production's organization, release of new kinds of production, performance of new kinds of work, providing new kinds of services, readiness to innovations and modifications.

Financial sustainability characterizes the state of financial resources of an enterprise, which ensures the efficient use of them for uninterrupted process of production and realization of goods.

Social sustainability means the involvement of all collective of enterprise into the social process, assistance for the growth of welfare of society, ensure of development and the level of social welfare of employees.

All parameters of economic sustainability are related and interacted. The level of development of each parameter impacts on total economic sustainability of an enterprise. And total economic sustainability of the enterprise makes the impact on the sustainability of its industry and sustainability of region of location. Industrial and regional sustainability form the common economic sustainability of a country.

Thus, sustainability of economic system can be determined as the state of a system, on which related parameters (financial, production, organizational, and others) are, beforehand, assigned limits of sustainability, and, simultaneously, are available to harmonious development and perfection, under any changes of external environment.

In the context of sustainable development of enterprise, necessary to identify the factors, which impact on its provision, as the following (Koryakov, 2012): 
1. Factors, which affect in social component of sustainable development of enterprise;

2. Factors, which affect on ecological component of sustainable development of enterprise;

3. Factors, which affect on economic component of sustainable development of enterprise.

According to some researchers, the approach to the analysis of factors of sustainable growth requires a systematic classification of factors on the basis of market categories, these factors can be differentiated into three groups (Koryakov, 2012):

- factors of supply;

- factors of demand;

- factors of distribution and redistribution.

The factors of supply determine the potential for economic growth.

We should point out, that factors of supply and demand are interconnected. For instance, unemployment slows the rate of capital accumulation, reduces the flow of investments and slows the expansion of production. Conversely, low rate of investments may be the main cause of unemployment. All of these three groups of factors are in the Table 3.

Table 3. Factors of sustainable development of enterprise.

\begin{tabular}{|c|c|c|}
\hline \multicolumn{3}{|c|}{ Factors of sustainable development of enterprise } \\
\hline Factors of supply & $\begin{array}{c}\text { Factors of distribution and } \\
\text { redistribution }\end{array}$ & Factors of demand \\
\hline $\begin{array}{l}\text { Include: } \\
\text { - number and quality of natural } \\
\text { resources involved in production; } \\
\text { - number and quality of labor } \\
\text { resources which have the demand on } \\
\text { the labor market; } \\
\text { - volume of capital resources involved } \\
\text { in production; } \\
\text { - useful information, innovations, and } \\
\text { new technologies, which started to } \\
\text { use in production. }\end{array}$ & $\begin{array}{l}\text { Determine the ability to increase } \\
\text { production through distribution and } \\
\text { redistribution of growing volume of } \\
\text { resources with the aim to obtain the } \\
\text { maximum amount of useful product of } \\
\text { specific assortment, which is different } \\
\text { from basis assortment and certain } \\
\text { quality. }\end{array}$ & $\begin{array}{l}\text { Characterize the ability to implement } \\
\text { material goods of certain quantity and } \\
\text { quality, generated through the use of } \\
\text { natural, labor, material, informational } \\
\text { and innovative factors in production, } \\
\text { according to existing common } \\
\text { demand. }\end{array}$ \\
\hline
\end{tabular}

Source: (Koryakov, 2012)

By exploring the problem of typology of factors of sustainable development of a company, it is necessary to turn to the economic theory which traditionally distinguishes three groups of production factors: land, labor, and capital (Marks \& Engels, 1984).

Based on the research of works related with sustainable development we found it necessary to add to the list of factors the following ones: innovations and management, information, ecology, and politics. All of these groups of factors are in the Table 4 (Koryakov, 2012). 
Table 4. Accordance of indicators of enterprise's efficiency and factors of sustainable development.

\begin{tabular}{|c|c|c|c|}
\hline $\begin{array}{c}\text { Factors of } \\
\text { sustainable } \\
\text { development }\end{array}$ & $\begin{array}{l}\text { Main measurement's } \\
\text { indicators }\end{array}$ & $\begin{array}{c}\text { Indicators of development's } \\
\text { efficiency to an appropriate } \\
\text { factor }\end{array}$ & $\begin{array}{l}\text { Examples of making } \\
\text { the sustainable } \\
\text { development to an } \\
\text { appropriate factor }\end{array}$ \\
\hline Natural & $\begin{array}{c}\text { Volume of resources } \\
\text { employed }\end{array}$ & Resource intensity of production & $\begin{array}{l}\text { Reengineering, } \\
\text { program of resource } \\
\text { efficiency increase }\end{array}$ \\
\hline Labor & $\begin{array}{l}\text { Number of population } \\
\text { involved }\end{array}$ & Labor production & $\begin{array}{l}\text { Increase the level of } \\
\text { education, health } \\
\text { system, labor } \\
\text { organization }\end{array}$ \\
\hline Capital & Cost of borrowed capital & Capital productivity & $\begin{array}{c}\text { Perfection of } \\
\text { production } \\
\text { organization } \\
\end{array}$ \\
\hline $\begin{array}{l}\text { Innovations and } \\
\text { management }\end{array}$ & $\begin{array}{c}\text { Expenditures on new } \\
\text { techniques, technologies }\end{array}$ & Production efficiency & $\begin{array}{c}\text { Development of } \\
\text { scientific researches, } \\
\text { innovations } \\
\text { implementation into } \\
\text { production }\end{array}$ \\
\hline Information & $\begin{array}{l}\text { Cost of information } \\
\text { system and software }\end{array}$ & $\begin{array}{l}\text { Speed of implementation of } \\
\text { innovations based on } \\
\text { information systems }\end{array}$ & $\begin{array}{l}\text { Perfection of } \\
\text { information system of } \\
\text { enterprise, } \\
\text { communications } \\
\text { development, } \\
\text { knowledge and } \\
\text { experience exchange }\end{array}$ \\
\hline Ecology & $\begin{array}{l}\text { The amount of emissions } \\
\text { into atmosphere }\end{array}$ & $\begin{array}{l}\text { Dynamics of environmental } \\
\text { pollution }\end{array}$ & $\begin{array}{l}\text { Implementation of } \\
\text { resources economy } \\
\text { programs, increase of } \\
\text { resources efficiency, } \\
\text { limitation of negative } \\
\text { impact on } \\
\text { environment. }\end{array}$ \\
\hline Politics & $\begin{array}{l}\text { Country's position in } \\
\text { Doing-Business indicator }\end{array}$ & $\begin{array}{l}\text { The level of social, fiscal and } \\
\text { bureaucratic burden }\end{array}$ & $\begin{array}{l}\text { Lobbying of industry's } \\
\text { interests on the } \\
\text { legislative level }\end{array}$ \\
\hline
\end{tabular}

Source: Author's own elaboration.

\subsection{Features of increasing the sustainability of a company in agribusiness industry}

There are three basic components of sustainable development characterizing by the following factors:

- «social» development - labor;

- «ecological» development - natural factors and ecology;

- «economic» development - capital, innovations and management, information, political lobby (Koryakov, 2012).

The key to survival and the basis for solid state of an enterprise is its sustainability, which is influenced by different factors: position of the company in financial market; the production of quality products which has demand; potential of enterprise to business cooperation; degree of dependence on external creditors and investors; presence of insolvent creditors; effectiveness of economic and financial transactions, etc. (Folomjev, 1995). 
Factors of constancy of economic development of the enterprise is also a number of threats and opportunities of external and internal environment. Important factors are: political situation, rational use of natural resource potential of the enterprise, results of market reforms of ownership relations, improve conditions and living environment of the population, preservation of ecological safety of the territory of an enterprise. Such a variety of factors necessitates a differentiation of economic sustainability of enterprises by types. The results of the differentiation are presented in Table 5 (Nureev, 2001).

Table 5. Differentiation of economic sustainability of enterprise by the types of influence.

\begin{tabular}{|c|c|c|}
\hline \multicolumn{3}{|c|}{ Economic sustainability of enterprise } \\
\hline Internal & External & Common (pricing) \\
\hline $\begin{array}{l}\text { The overall financial position of } \\
\text { the company, which ensures the } \\
\text { consistently high results of } \\
\text { operation, which is based on the } \\
\text { principle of active response to the } \\
\text { changing internal and external } \\
\text { factors. }\end{array}$ & $\begin{array}{l}\text { Due to stable economic } \\
\text { environment within which the } \\
\text { activities of the enterprise is } \\
\text { implementing; achieves by the } \\
\text { appropriate market economy } \\
\text { management system in the entire } \\
\text { country }\end{array}$ & $\begin{array}{l}\text { The cash flows, which ensures a } \\
\text { constant excess of revenues } \\
\text { (income) over } \\
\text { (expenditure) }\end{array}$ \\
\hline
\end{tabular}

Source: (Koryakov, 2012).

Factors of sustainable development of the enterprise should be explored in such aggregated areas:

- global conditions (state of the world economy, globalization of the economy, external threats, participation in cross-border and global cooperation, regional integration);

- material, physical capital (quantity and quality of land, size, structure, status, and effectiveness of fixed assets, etc.);

- human capital (number and structure of population, structure of employment, cultural and professional level of population);

- financial resources of enterprise;

- perfection of market relations (level of concentration, market infrastructure, level of privatization, level of state regulation);

- non-economic factors (political, social and cultural environment) (Koryakov, 2012).

The process of sustainable economic development, as well as the level of competitiveness of the national economy depends on such groups of factors macro-level:

- level of provision of economy with natural, labor, production, information and other resources;

- degree of implementation's efficiency by the government demographic, investment, innovation and regulatory policy, due to that in the country are optimizing the demographic structure of the population and forming the regulatory environment that encourages business to effective functioning, while other countries and businesses to invest in promising sectors of the national economy;

- opportunities for business owners to realize the competitive advantages of the existing resource potential and the regulatory environment with the aim to implement this or that type 
of intense economic reproduction and achieve on this basis a high level of efficiency and, eventually, sustainable economic development.

Sustainable development, as well as the competitiveness of a country, is the result of permanent interaction of all subjects of economic relationship in the country. Consequently, the research of economic categories should consider the analysis of all factors which influence on forming of conditions of sustainable economic development of a country on each stage of extended production and on all level of competition, namely, enterprise, industry, form of economic activity, and entire economy (Koryakov, 2012).

Considering the definition "sustainability" according to agriculture, it can be characterized, as the ability to resist against negative impact of various factors of production. On sustainability of agricultural production impacts the set of various factors, which can be classified on external and internal (Kuzmenko \& Gritcenko, 2016).

\begin{tabular}{|c|c|c|c|}
\hline \multicolumn{4}{|c|}{ EXTERNAL FACTORS } \\
\hline$\downarrow$ & $\downarrow$ & $\downarrow$ & $\downarrow$ \\
\hline $\begin{array}{c}\text { General economic } \\
\text { factors }\end{array}$ & Market factors & Natural factors & Other factors \\
\hline Regulatory & Price regulation & Droughts & Political crisis \\
\hline Inflation rate & Market infrastructure & Floods & Wars \\
\hline $\begin{array}{l}\text { Decline of national } \\
\text { income }\end{array}$ & Competitors & Freezing & $\begin{array}{l}\text { Demographic } \\
\text { problems }\end{array}$ \\
\hline $\begin{array}{l}\text { Economic policy of the } \\
\text { Government }\end{array}$ & Suppliers of resources & Dust stomrs & $\begin{array}{l}\text { Socio-political } \\
\text { instability }\end{array}$ \\
\hline \multicolumn{4}{|c|}{ ECONOMIC SUSTAINABILITY OF AGRICULTURAL PRODUCTION } \\
\hline $\begin{array}{c}\text { Volume of reserve and } \\
\text { seasonal inventory }\end{array}$ & $\begin{array}{c}\text { Level of investment } \\
\text { risk }\end{array}$ & Marketing policy & $\begin{array}{l}\text { Rational allocation and } \\
\text { mix of branches }\end{array}$ \\
\hline $\begin{array}{c}\text { Production } \\
\text { management }\end{array}$ & Investment activity & Labor organization & Quality of production \\
\hline $\begin{array}{l}\text { Level of technical } \\
\text { equipment }\end{array}$ & $\begin{array}{l}\text { Investment } \\
\text { management }\end{array}$ & $\begin{array}{c}\text { Strategy and tactics of } \\
\text { organization } \\
\text { development }\end{array}$ & $\begin{array}{c}\text { Financial statement of } \\
\text { enterprise }\end{array}$ \\
\hline $\begin{array}{l}\text { Technological } \\
\text { innovations }\end{array}$ & $\begin{array}{l}\text { Overrun of investment } \\
\text { resources }\end{array}$ & $\begin{array}{l}\text { Efficiency and quality } \\
\text { of enterprise } \\
\text { management }\end{array}$ & $\begin{array}{c}\text { Resource and } \\
\text { production potential }\end{array}$ \\
\hline Operational factors & Investment factors & Managerial factors & Other factors \\
\hline$\uparrow$ & $\uparrow$ & $\uparrow$ & $\uparrow$ \\
\hline \multicolumn{4}{|c|}{ INTERNAL FACTORS } \\
\hline
\end{tabular}

Figure 3. Factors of economic sustainability of agricultural production.

Source: (Kuzmenko \& Gritcenko, 2016)

Sustainable agriculture integrates three main goals - environmental health, economic profitability, and social and economic equity. 
There are specific strategies for realizing these broad themes or goals. The strategies are grouped according to three separate though related areas of concern: Farming and Natural Resources, Plant and Animal Production Practices, and the Economic, Social and Political Context. They represent a range of potential ideas for individuals committed to interpreting the vision of sustainable agriculture within their own circumstances.

Sustainable production practices involve a variety of approaches. Specific strategies must take into account topography, soil characteristics, climate, pests, local availability of inputs and the individual grower's goals. Despite the site-specific and individual nature of sustainable agriculture, several general principles can be applied to help growers select appropriate management practices:

- Selection of species and varieties that are well suited to the site and to conditions on the farm;

- Diversification of crops (including livestock), harvesting and cultural practices to enhance the biological and economic stability of the farm;

- Management of the soil to enhance and protect soil quality;

- Efficient and humane use of inputs; and

— Consideration of farmers' goals and lifestyle choices.(Feenstra, Ingels, \& Campbell, 2016)

To increasing of sustainability of agricultural production are helping technical factors, which include improvement of existing and creation of new machineries and implementation of resource-saving technologies of agricultural crop cultivation. In chapter 3 will be identified the weaknesses of investigated enterprise, which helping to inspect the most prospective direction of activity aimed at improving of economic sustainability of the enterprise (Kuzmenko \& Gritcenko, 2016). 


\section{Research methodology}

\subsection{Objective of the study and research hypothesis}

The importance of the research problem of the study is to improve the company's competitiveness of the company by identifying the main problems in the production process.

Under the objects of supervision is considered JSC "Novoazovskoe" of Azovsky German National district of Omsk region. The object of research is an economic sustainability of a company, and processes related with goods production. The subject of research is increasing of economic sustainability of a company by using modern harvesting system. In this Master thesis will be considered the implementation of the most modern harvesting system for haylage.

The research hypotheses are the following:

- after implementation of a new haylage harvesting system, the company will increase the volume of a good haylage in total harvested mass of haylage. Under the good haylage implies the haylage with quantity remains of $80 \%$ and quality remains of $80-90 \%$ (Labocky, 2013);

- implementation of the new haylage harvesting system can bring additional revenues in total income of a company, due to selling the surplus of good haylage on the market of Omsk region.

\subsection{Description of data collection}

Data for theoretical part and literature review will be collected from the various sources, related with the theme of Master thesis and/or giving the explanation of the processes and definition required for understanding the description of enterprise's activity, existing harvesting system, and proposed harvesting system.

For searching the theoretical information and data, related to company's economic sustainability, will be used:

- open internet sources, related with financial, statistical, managerial and other information; 
- libraries of OmSAU, IPB and international databases and libraries;

- scientific and specialized online and regular journals of both countries, as well as international ones;

- data from governmental portals and sources related with the theme of Master thesis;

- information from the companies-producers of agricultural machineries, required for modern haylage harvesting process.

For data collection, related to financial report and other reports and information of company, will be asked JSC "Novoazovskoe" directly. Necessary to obtain the data for the last 3 years of enterprise activity. For analysis of activity will be necessary to obtain the reports, such as annual financial documents statement (Balance sheet, Income Statement, experts' statements and other reports). Also, will be used data of Rosstat.

Data about business activity and about the crop production and harvesting processes used in a company were collected during the November - December 2016. Theoretical information was surveyed during the period from November 2016 till January 2017. Current data about results of production process and economic and financial results of companies was collected and analysed during the January - February 2017. Considering the opportunity of application modern haylage harvesting process, as well as calculation of proposed financial results were in March-May 2017.

\subsection{Description of data analysis}

Firstly, will be given the meanings for the terms, such as: "Economical efficiency", "Economic sustainability", "Competitiveness" and "Economic solidity". Also, will be presented types of economic sustainability and factors, which are affecting on stable development of a company. Additionally, in the thesis will be indicated the special features of increasing the sustainability of a company in agribusiness industry.

Further, will be implemented an analysis of business activity of a company. In this section will be inspected its legal statutes and management levels. Also will be analysed their financial and economic activity. It will be implemented by analyse of bookkeeping statement and other sources with the following indicators:

- Changing of balance sheet structure from year to year;

- Changing in financial results from year to year;

- Dynamics of changes in number and amount of current and non-current assets;

- Dynamics of changes in square and quality of lands;

- Dynamics of changes in average number of employees;

- Dynamic in production of various kinds of agricultural products.

All of these analyses will be implemented in several different types of analysis with usage of comparative method:

— Vertical analysis - for surveying the structure of specified data; 
- Year-to-year horizontal analysis - for surveying the dynamic of changes from each year to the following year;

- Year-to-base horizontal analysis - for surveying the dynamic of changes from each year to the base year for comparison the total changes.

In the second part also will be implemented the evaluation of financial-economic activity according to the following ratios:

- General ratios;

- Liquidity ratios;

- Profitability indicator ratios;

- Operating performance ratios;

- Turnover ratios.

According to the goods production analysis will be implemented the CVP-analysis for separated kinds of production: milk and grain. For both of these kinds will be calculated the breakeven points and financial strength indicators.

In final section of third chapter will be made the SWOT Analysis, which can help to identify the weakness of a company and to improve the economic sustainability of enterprise.

In the final chapter of Master thesis will be proposed the ways to improve the economic sustainability. Namely: the improving of haylage harvesting process, and receiving the additional revenues from selling the surplus. Will be used the comparative method in the process of selection the most appropriate way to improve the haylage harvesting process. 


\section{Organizational and economical evaluation of JSC "Novoazovskoe"}

\subsection{Legal status and management system of JSC "Novoazovskoe"}

Joint stock company "Novoazovskoe" (hereinafter - JSC "Novoazovskoe" and/or JSC) was registered on $15^{\text {th }}$ October 2002 at 646886, Omsk region, Azovsky German National district, village Berezovka, Shkolnaya street, 4. The company was assigned the Primary State Registration Number (PSRN) 1025501515302 and issued the Tax Individual Number (TIN) 5509001119.

Main kind of activity according to the code of Common Classificatory of Economic Activity Types (hereinafter - CCEAT): 01.21 - Breeding of cattle.Additional kinds of activity:

- Growing of feed crops, harvesting of plant feeds (CCEAT - 01.11.6);

- Pigs breeding (CCEAT - 01.23);

- Production of wooden construction and carpenter wares (20.30.1).

Since 2012 and to present the head of the enterprise is M.M. Sharapov. Position of the head General Director of JSC.

For further research of enterprise, it is necessary to make the analysis of organizational structure on the company. Main characteristics of structure's quality of any economic system are the equilibrium and proportionality of its parts interconnections (subdivisions and employees). Organizational structure of enterprise is the ordered collection of solidity connected subsystems ensuring the functioning and development of organization as an aggregate. Organizational structure of JSC "Novoazovskoe" is presented on the Figure 3. 


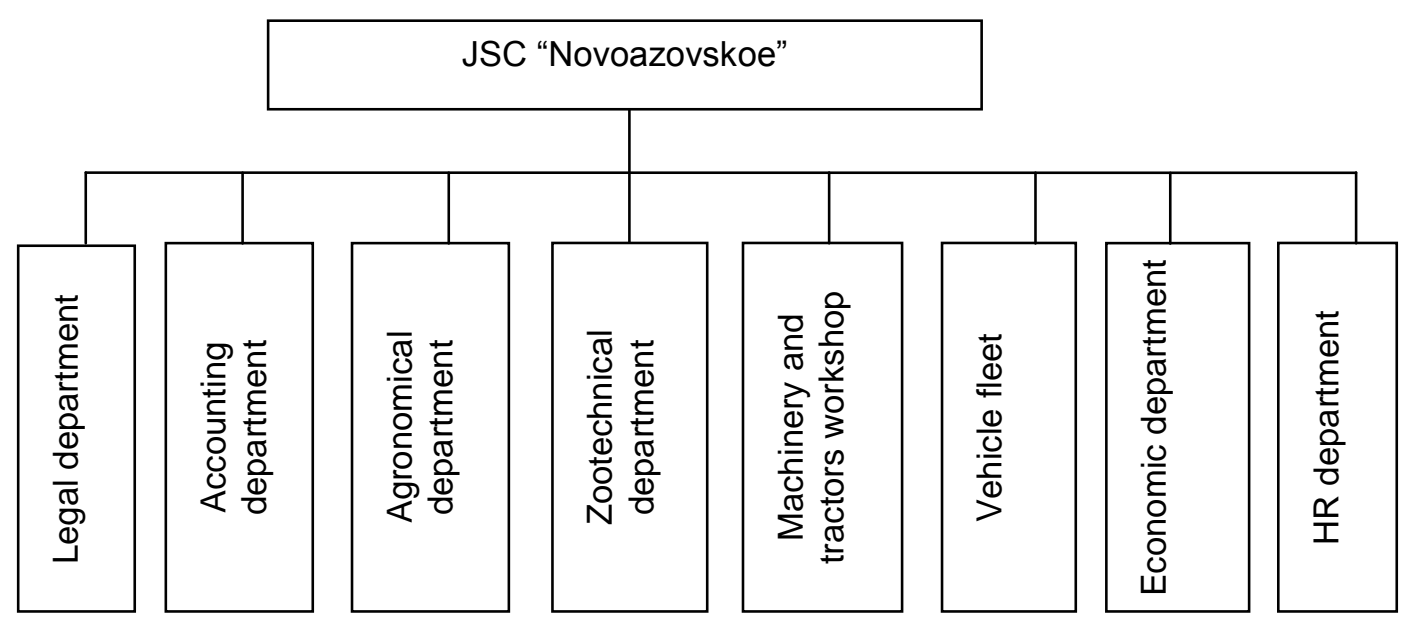

Figure 3. Organizational structure of JSC "Novoazovskoe".

Source: Author's own elaboration based on managerial data of JSC "Novoazovskoe",

JSC "Novoazovskoe" is characterized by linear-functional type of organizational structure. Linearfunctional management structure ensures such a diversification of managerial work, in which the linear managerial elements provide overall leadership and coordination, and the functional ones consult and develop specific questions (Goldstein, 2003). First managerial level of JSC "Novoazovskoe" is presented on the Figure 4.

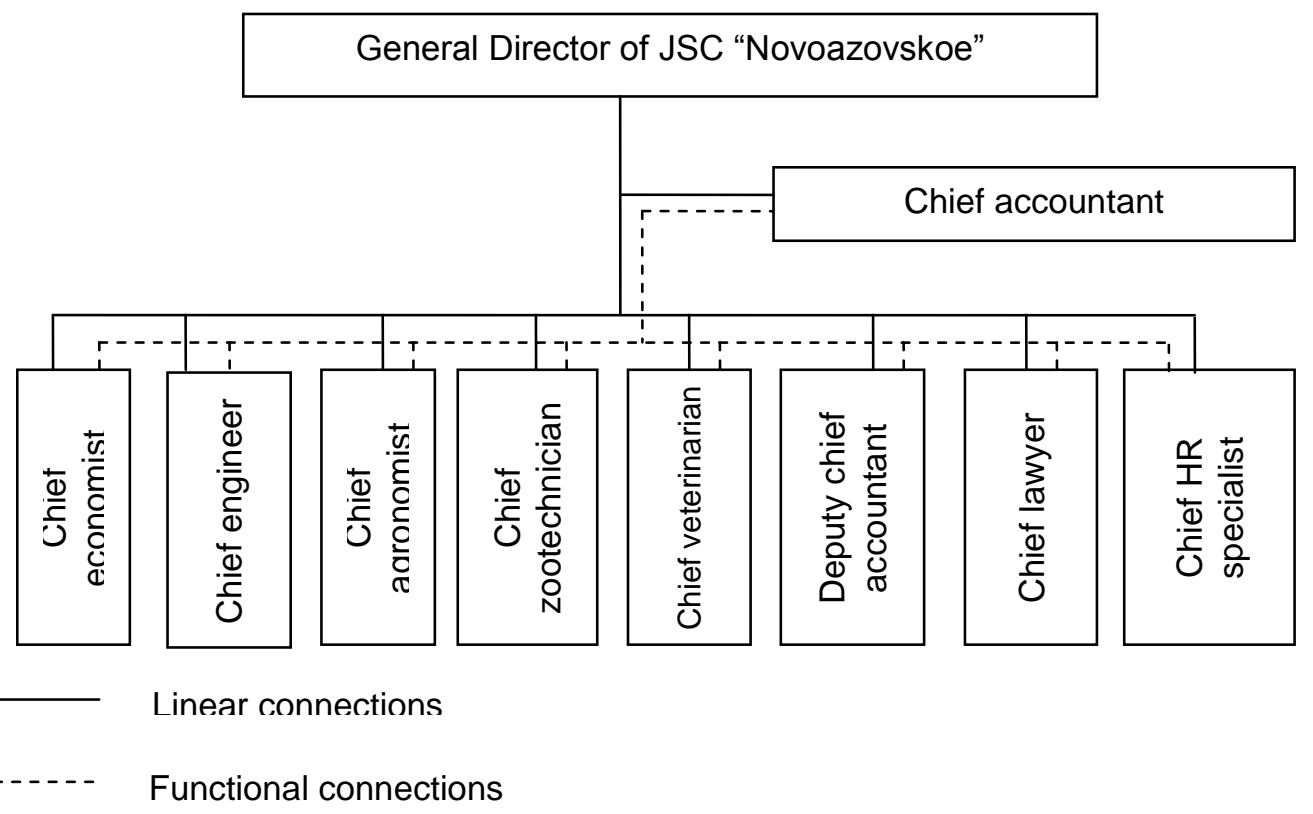

Figure 4. First managerial level of JSC "Novoazovskoe".

Source: Author's own elaboration based on managerial data of JSC "Novoazovskoe",

As can be seen from the Figure 4, the top-managerial level is presented by the head of JSC. In direct subordination is the chief accountant (Vice Director of JSC). In linear subordination are chief 
engineer, chief agronomist, chief zootechnician, chief veterinarian, and deputy chief accountant, chief economist, chief lawyer, and chief HR specialist. Chiefs are in functional subordination to chief accountant. This managerial structure eliminates the duplicated and inconsistent orders. If the inconsistent orders exist, employees should follow to the linear manager's orders. Schematically the second managerial level of JSC "Novoazovskoe" is presented on the Figure 5.

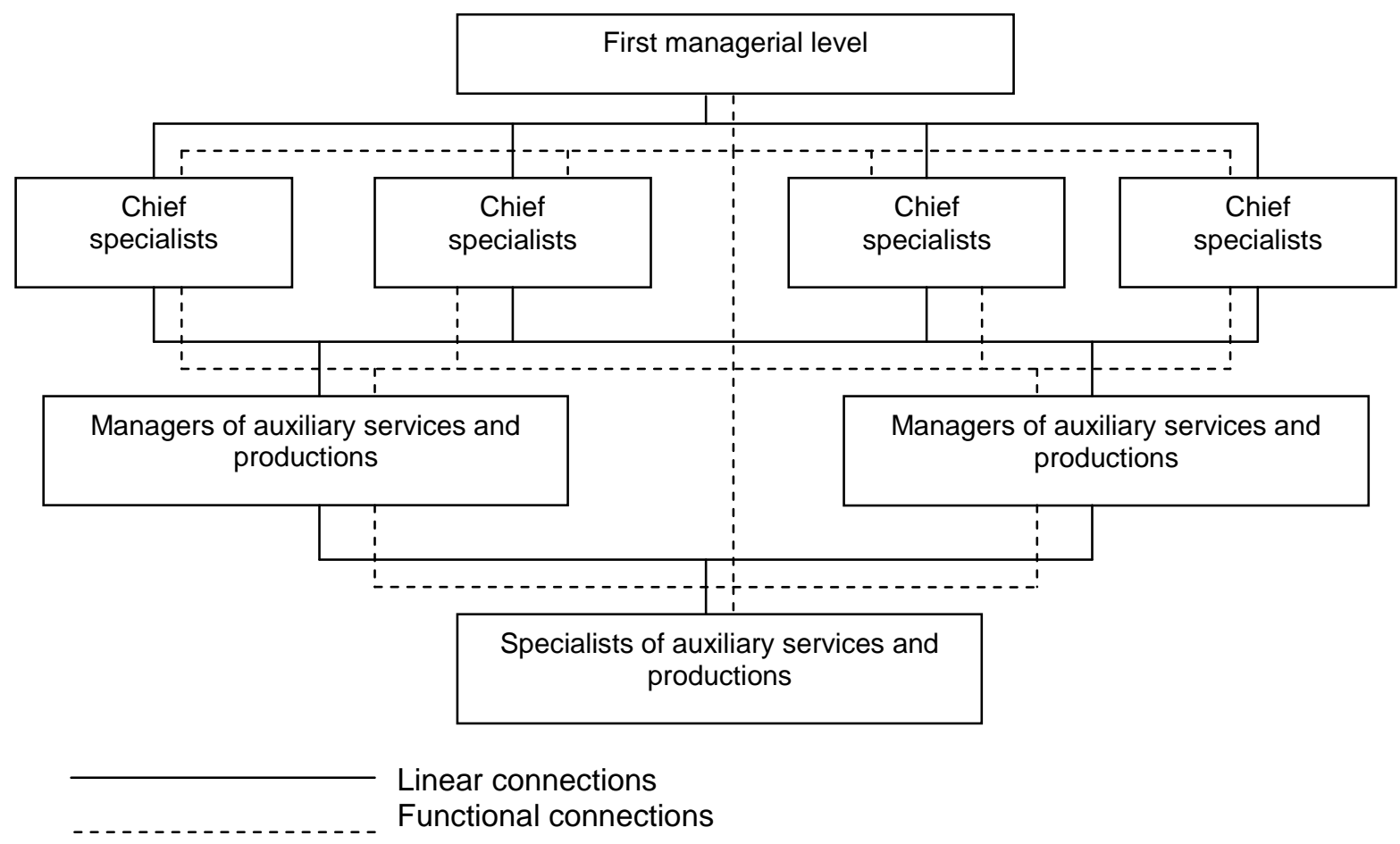

Figure 5. Scheme of the second managerial level of JSC "Novoazovskoe".

Source: Author's own elaboration based on managerial data of JSC "Novoazovskoe",

Second managerial level of JSC "Novoazovskoe" is presented by the managers of auxiliary services and productions and specialists linearly subordinated to chief specialists. Under the subordination of auxiliary services and productions managers are specialist of these services and productions. To each chief specialist subordinates the manager of particular auxiliary service or production. That avoids dual subordination and duplication of orders. The third managerial level of JSC "Novoazovskoe" is the structure of sections' management. By each of sections leads the section manager, which linearly subordinates to chief accountant, and functionally - to chief specialists. Managerial structure of each section is nearly similar.

As follows from the aforesaid, the structure of JSC "Novoazovskoe" is linear with direct subordination, balanced in terms of number of services and departments, as well as a number of linear managers. 


\subsection{Characteristic of activity of JSC "Novoazovskoe"}

JSC "Novoazovskoe" is located on the territory of Azovsky German National district of Omsk Region. Azovsky district is in the south forest-steppe zone of Omsk region. Climate of Azovsky district is typically continental, and forming by the cold arctic air masses from the North and from Kazakhstan. Common features of temperature regime are characterized by hard and long winter, short but hot summer. Common positive features are the abundance of light and heat during the vegetative period with positive temperatures, which accelerates vegetation of plants. The average monthly temperature of the warmest month (July) - 18 degrees, and the coldest month (January) 19 degrees cold. Stable snow cover forms at 6-12 of November. Annual precipitation is $300 \mathrm{~mm}$. Prevailing winds from autumn to spring are the south-western winds, and on summer - northwestern ones. Soil cover is represented mainly by: ordinary chernozems (black soils) with a predominance of heavy mechanical composition, which is resistant to wind and water erosion. (OmskPortal, 2017)

For making the estimation of economic and business efficiency of enterprise's activity, necessary to make the analysis of the following indicators:

- Changing of balance sheet structure from year to year;

- Changing in financial results from year to year;

- Dynamics of changes in number and amount of current assets;

- Dynamics of changes in square and quality of lands;

- Dynamics of changes in average number of employees;

- Production of various kinds of agricultural products.

Firstly, we need to inspect the Balance sheets and the Income statements of JSC "Novoazovskoe" as the most important and reliable source of information. Also, need to make the vertical analysis and horizontal analysis to get more information about the trends of enterprise development. The analysis of balance's structure made for 3 accounting years. Data obtained from accounting statements (Form 1), and presented in the Tables 6 (vertical analysis) and 7 (year-to-year horizontal analysis). "Year-to-year" analysis means, that all years will be compared in the sequence of ascending. Results are presented in Tables 6 and 7. 
Table 6. Balance sheet of JSC "Novoazovskoe" for 2013-2015, vertical analysis.

\begin{tabular}{|c|c|c|c|c|c|c|}
\hline $\begin{array}{c}\text { Balance Sheets, in thousands of } \\
\text { RUB }\end{array}$ & \multicolumn{2}{|c|}{2013} & \multicolumn{2}{|c|}{2014} & \multicolumn{2}{|c|}{2015} \\
\hline \multicolumn{7}{|l|}{ Noncurrent assets } \\
\hline Fixed assets & 135113 & $42,28 \%$ & 150735 & $43,24 \%$ & 160144 & $43,46 \%$ \\
\hline Financial investments & 0 & $0,00 \%$ & 0 & $0,00 \%$ & 0 & $0,00 \%$ \\
\hline Other assets & 0 & $0,00 \%$ & 9115 & $2,62 \%$ & 15874 & $4,31 \%$ \\
\hline Total noncurrent assets & 135113 & $42,28 \%$ & 159850 & $45,86 \%$ & 176018 & $47,77 \%$ \\
\hline \multicolumn{7}{|l|}{ Current assets } \\
\hline Inventory & 125688 & $39,33 \%$ & 130491 & $37,44 \%$ & 147155 & $39,94 \%$ \\
\hline Accounts receivable & 9673 & $3,03 \%$ & 7676 & $2,20 \%$ & 9838 & $2,67 \%$ \\
\hline Cash and cash equivalents & 49069 & $15,36 \%$ & 50544 & $14,50 \%$ & 35449 & $9,62 \%$ \\
\hline $\begin{array}{l}\text { Prepaid expenses and other current } \\
\text { assets }\end{array}$ & 0 & $0,00 \%$ & 0 & $0,00 \%$ & 0 & $0,00 \%$ \\
\hline Total current assets & 184430 & $57,72 \%$ & 188711 & $54,14 \%$ & 192442 & $52,23 \%$ \\
\hline Total assets & 319543 & $100,00 \%$ & 348561 & $100,00 \%$ & 368460 & $100,00 \%$ \\
\hline \multicolumn{7}{|l|}{ LIABILITIES AND EQUITY } \\
\hline \multicolumn{7}{|l|}{ Equity } \\
\hline Common stock & 102 & $0,03 \%$ & 102 & $0,03 \%$ & 102 & $0,03 \%$ \\
\hline Revaluation of non-current assets & 35898 & $11,23 \%$ & 32547 & $9,34 \%$ & 29462 & $8,00 \%$ \\
\hline Reserved capital & 14020 & $4,39 \%$ & 18955 & $5,44 \%$ & 21924 & $5,95 \%$ \\
\hline Accumulated profit & 268614 & $84,06 \%$ & 296531 & $85,07 \%$ & 313143 & $84,99 \%$ \\
\hline Total equity & 318634 & $99,72 \%$ & 348135 & $99,88 \%$ & 364631 & $98,96 \%$ \\
\hline \multicolumn{7}{|l|}{ Long-term liabilities } \\
\hline Long-term debt & 0 & $0,00 \%$ & 0 & $0,00 \%$ & 0 & $0,00 \%$ \\
\hline Other long-term liabilities & 0 & $0,00 \%$ & 0 & $0,00 \%$ & 0 & $0,00 \%$ \\
\hline Total long-term liabilities & 0 & $0,00 \%$ & 0 & $0,00 \%$ & 0 & $0,00 \%$ \\
\hline \multicolumn{7}{|l|}{ Short-term liabilities } \\
\hline Accounts payable & 832 & $0,26 \%$ & 426 & $0,12 \%$ & 3829 & $1,04 \%$ \\
\hline Deferred revenue & 77 & $0,02 \%$ & 0 & $0,00 \%$ & 0 & $0,00 \%$ \\
\hline Short-term debt & 0 & $0,00 \%$ & 0 & $0,00 \%$ & 0 & $0,00 \%$ \\
\hline Total short-term liabilities & 909 & $0,28 \%$ & 426 & $0,12 \%$ & 3829 & $1,04 \%$ \\
\hline Total liabilities and equity & 319543 & $100,00 \%$ & 348561 & $100,00 \%$ & 368460 & $100,00 \%$ \\
\hline
\end{tabular}

Source: Author's own elaboration based on bookkeeping statement of JSC "Novoazovskoe" for 2013-2015 
Table 7. Year-to-year horizontal analysis of JSC "Novoazovskoe" Balance sheets.

\begin{tabular}{|c|c|c|c|c|c|c|c|}
\hline \multirow{2}{*}{$\begin{array}{c}\text { Balance Sheets, in thousands } \\
\text { of RUB }\end{array}$} & \multicolumn{3}{|c|}{ Year } & \multicolumn{2}{|c|}{2014 to 2013} & \multicolumn{2}{|c|}{2015 to 2014} \\
\hline & 2013 & 2014 & 2015 & $\begin{array}{c}\text { In } \\
\text { amount }\end{array}$ & $\begin{array}{c}\% \text { of } \\
\text { previous }\end{array}$ & $\begin{array}{c}\text { In } \\
\text { amount }\end{array}$ & $\begin{array}{c}\% \text { of } \\
\text { previous }\end{array}$ \\
\hline \multicolumn{8}{|l|}{ ASSETS } \\
\hline \multicolumn{8}{|l|}{ Noncurrent assets } \\
\hline Fixed assets & 135113 & 150735 & 160144 & 15622 & $111,6 \%$ & 9409 & $106,2 \%$ \\
\hline Financial investments & 0 & 0 & 0 & 0 & $0,00 \%$ & 0 & $0,00 \%$ \\
\hline Other assets & 0 & 9115 & 15874 & 9115 & - & 6759 & $174,2 \%$ \\
\hline Total noncurrent assets & 135113 & 159850 & 176018 & 24737 & $118,3 \%$ & 16168 & $110,1 \%$ \\
\hline \multicolumn{8}{|l|}{ Current assets } \\
\hline Inventory & 125688 & 130491 & 147155 & 4803 & $103,8 \%$ & 16664 & $112,8 \%$ \\
\hline Accounts receivable & 9673 & 7676 & 9838 & -1997 & $79,4 \%$ & 2162 & $128,2 \%$ \\
\hline Cash and cash equivalents & 49069 & 50544 & 35449 & 1475 & $103,0 \%$ & -15095 & $70,1 \%$ \\
\hline $\begin{array}{l}\text { Prepaid expenses and other } \\
\text { current assets }\end{array}$ & 0 & 0 & 0 & - & 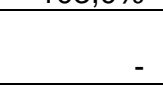 & . & \\
\hline Total current assets & 184430 & 188711 & 192442 & 4281 & $102,3 \%$ & 3731 & $102,0 \%$ \\
\hline Total assets & 319543 & 348561 & 368460 & 29018 & $109,1 \%$ & 19899 & $105,7 \%$ \\
\hline \multicolumn{8}{|l|}{ LIABILITIES AND EQUITY } \\
\hline \multicolumn{8}{|l|}{ Equity } \\
\hline Common stock & 102 & 102 & 102 & 0 & $100,0 \%$ & 0 & $100,0 \%$ \\
\hline $\begin{array}{l}\text { Revaluation of non-current } \\
\text { assets }\end{array}$ & 35898 & 32547 & 29462 & -3351 & $90,7 \%$ & -3085 & $90,5 \%$ \\
\hline Reserved capital & 14020 & 18955 & 21924 & 4935 & $135,2 \%$ & 2969 & $115,7 \%$ \\
\hline Accumulated profit & 268614 & 296531 & 313143 & 27917 & $110,4 \%$ & 16612 & $105,6 \%$ \\
\hline Total equity & 318634 & 348135 & 364631 & 29501 & $109,3 \%$ & 16496 & $104,7 \%$ \\
\hline \multicolumn{8}{|l|}{ Long-term liabilities } \\
\hline Long-term debt & 0 & 0 & 0 & 0 & $0,00 \%$ & 0 & $0,00 \%$ \\
\hline Other long-term liabilities & 0 & 0 & 0 & 0 & $0,00 \%$ & 0 & $0,00 \%$ \\
\hline Total long-term liabilities & 0 & 0 & 0 & 0 & $0,00 \%$ & 0 & $0,00 \%$ \\
\hline \multicolumn{8}{|l|}{ Short-term liabilities } \\
\hline Accounts payable & 832 & 426 & 3829 & -406 & $51,2 \%$ & 3403 & $898,8 \%$ \\
\hline Deferred revenue & 77 & 0 & 0 & -77 & $0,0 \%$ & 0 & $0,0 \%$ \\
\hline Short-term debt & 0 & 0 & 0 & 0 & $0,0 \%$ & 0 & $0,0 \%$ \\
\hline Total short-term liabilities & 909 & 426 & 3829 & -483 & $46,9 \%$ & 3403 & $898,8 \%$ \\
\hline $\begin{array}{l}\text { Total liabilities and } \\
\text { stockholders' equity }\end{array}$ & 319543 & 348561 & 368460 & 29018 & $109,1 \%$ & 19899 & $105,7 \%$ \\
\hline
\end{tabular}

Source: Author's own elaboration based on bookkeeping statement of JSC "Novoazovskoe" for 2013-2015.

As we can see, the most impressive growth in year-to-year horizontal analysis in percentage showed by the item "Accounts payable" - 898,8\% (3 403 thousand rubles in money) from 2015 to 2014, and in monetary term - by the item "Accumulated profit" - 27917 thousand rubles (110,4\%) from 2014 to 2013. In general, mostly all of the items showed the positive trend, except the item "Revaluation of non-current assets" - decline from year to year. Also, it is necessary to note, that an enterprise doesn't have the items "Financial investment", "Long-term debt" and "Short-term debt". That means that JSC "Novoazovskoe" concentrated on investing of its surplus funds into its 
business activity. Also, company doesn't borrow the loans and credits. More graphically it's presented on the Figures 6-9.

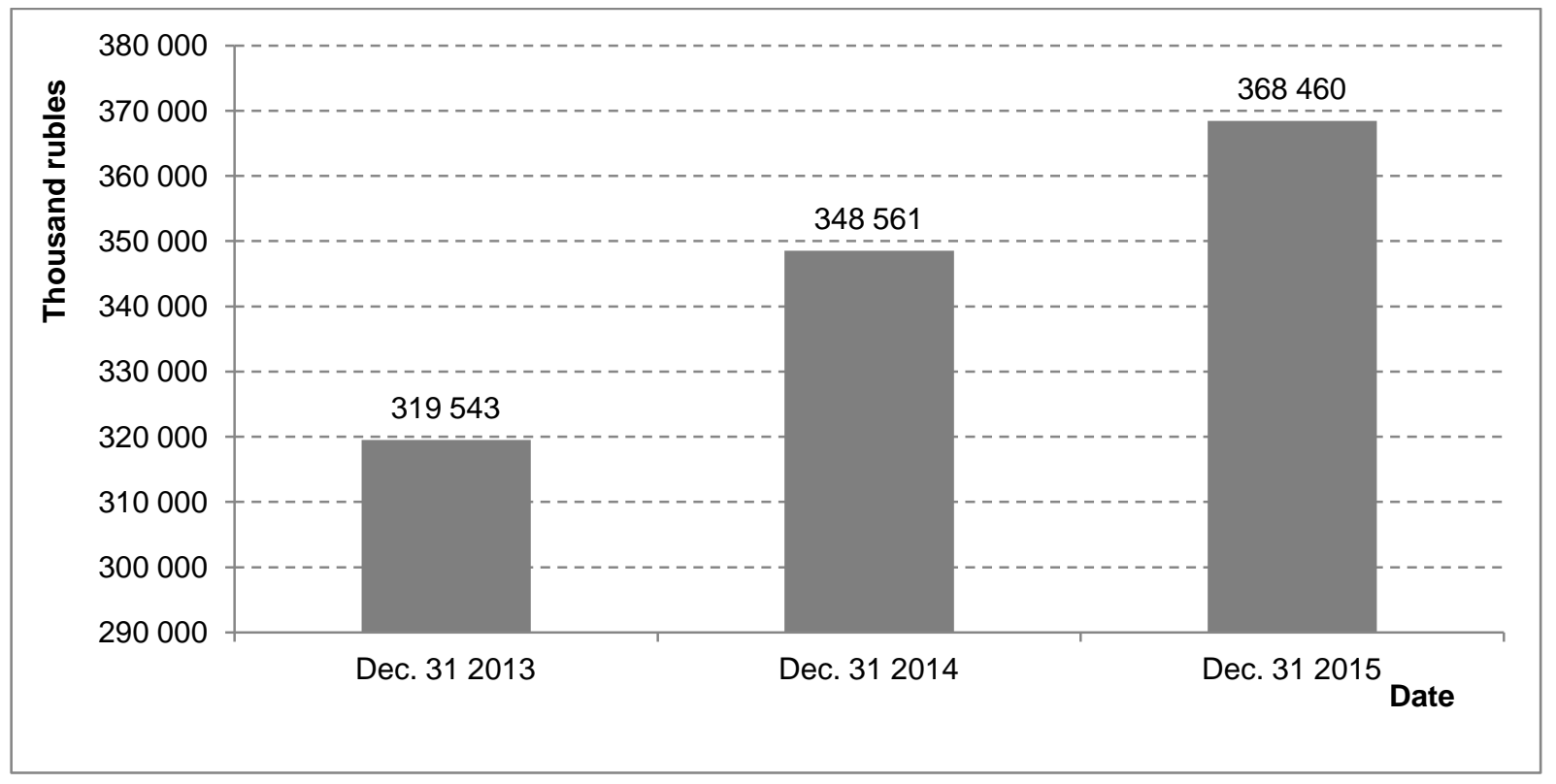

Figure 6. Dynamic of balance sheet's total results changing.

Source: Author's own elaboration based on bookkeeping statement of JSC "Novoazovskoe" for 2013-2015.

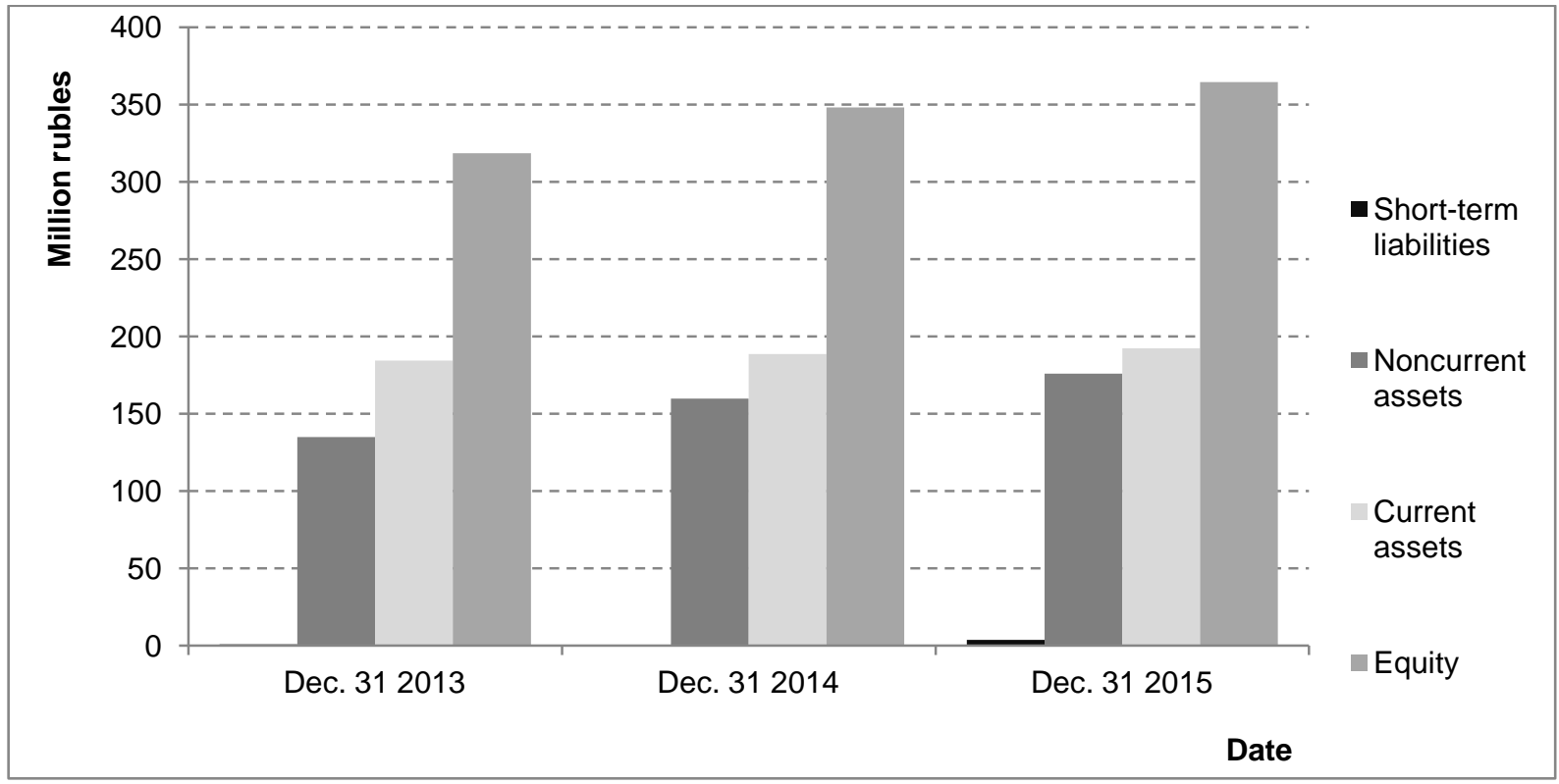

Figure 7. Comparison of the balance sheet's items for 3 years

Source: Author's own elaboration based on bookkeeping statement of JSC "Novoazovskoe" for 2013-2015. 


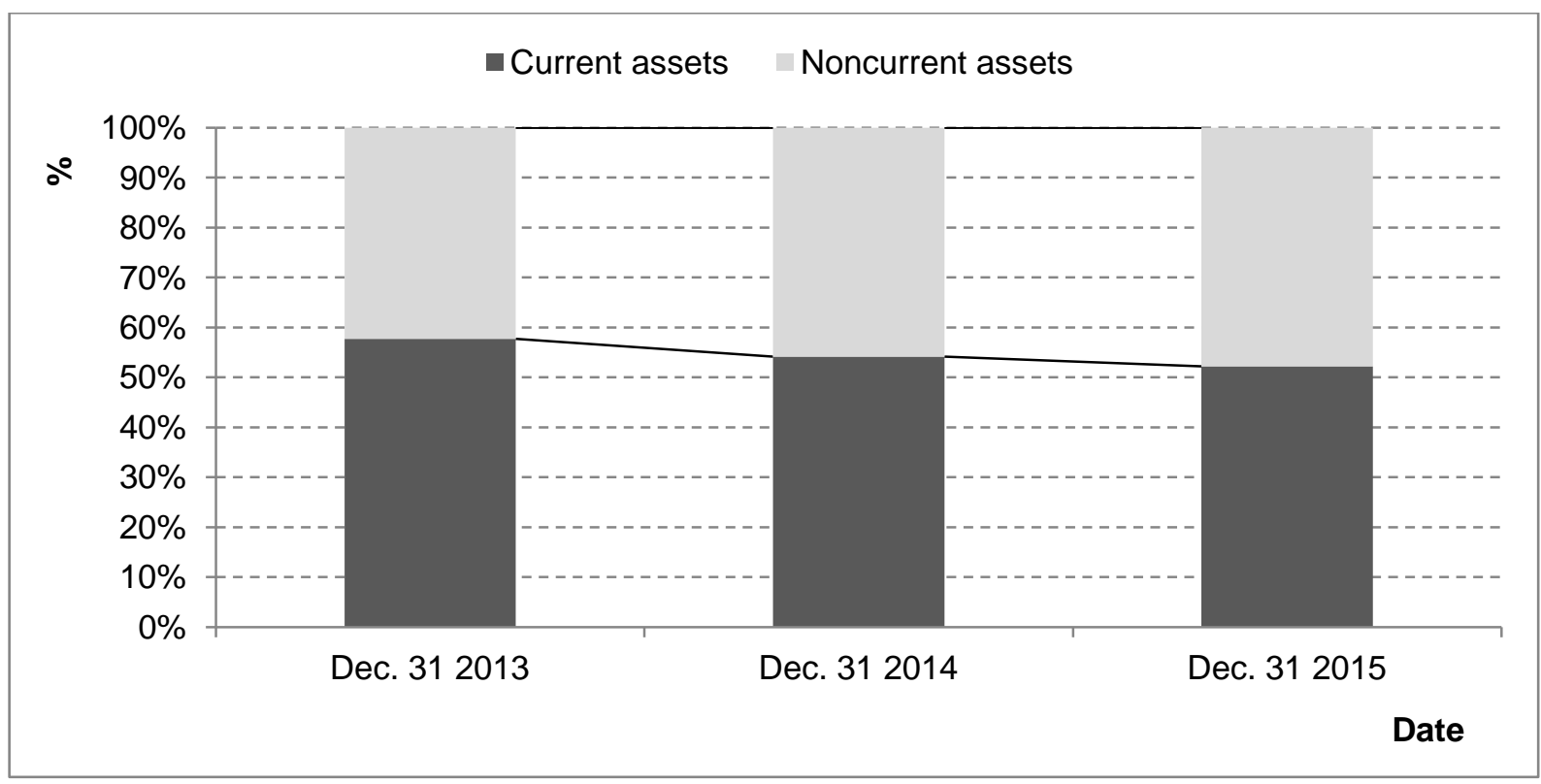

Figure 8. Structure of Assets side of a Balance

Source: Author's own elaboration based on bookkeeping statement of JSC "Novoazovskoe" for 2013-2015.

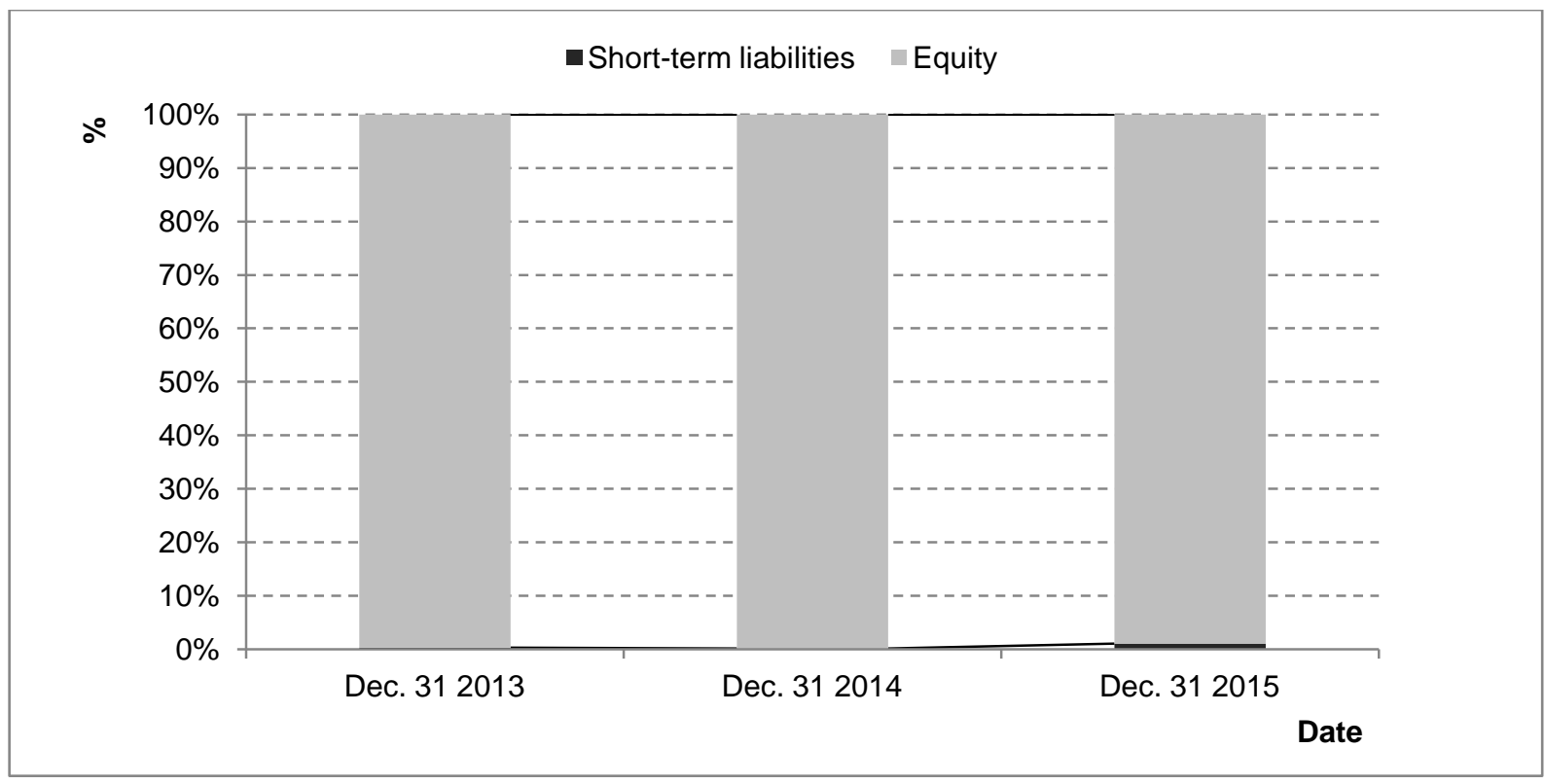

Figure 9. Structure of Liabilities side of a Balance.

Source: Author's own elaboration based on bookkeeping statement of JSC "Novoazovskoe" for 2013-2015.

For the further analysis of business activity of an enterprise it's necessary to analyse the Income statement of JSC "Novoazovskoe" for last 3 years. Need to make the vertical analysis and horizontal analysis to get more information about the trends of enterprise development. The analysis of income statement's structure made for 3 accounting years. Data obtained from accounting statements (Form 2), and presented in the Table 8 (vertical analysis) and 9 (year-toyear horizontal analysis). 
Table 8. Income statement of JSC "Novoazovskoe" for 2013-2015, vertical analysis.

\begin{tabular}{|c|c|c|c|c|c|c|}
\hline \multirow{2}{*}{$\begin{array}{c}\text { In thousands of RUB } \\
\text { Revenues }\end{array}$} & \multicolumn{2}{|c|}{2013} & \multicolumn{2}{|c|}{2014} & \multicolumn{2}{|c|}{2015} \\
\hline & amount & In \% & amount & $\ln \%$ & amount & $\ln \%$ \\
\hline Plant growing & 30896 & $14,1 \%$ & 56624 & $28,6 \%$ & 38823 & $20,3 \%$ \\
\hline Animal breeding & 187212 & $85,6 \%$ & 140732 & $71,1 \%$ & 151935 & $79,3 \%$ \\
\hline Other goods & 6 & $0,0 \%$ & 0 & $0,0 \%$ & 0 & $0,0 \%$ \\
\hline Other services & 661 & $0,3 \%$ & 638 & $0,3 \%$ & 757 & $0,4 \%$ \\
\hline Total revenues & 218775 & $100,0 \%$ & 197994 & $100,0 \%$ & 191515 & $100,0 \%$ \\
\hline \multicolumn{7}{|l|}{ Cost of revenues } \\
\hline Plant growing & 28205 & $12,9 \%$ & 53977 & $27,3 \%$ & 40472 & $21,1 \%$ \\
\hline Animal breeding & 168524 & $77,0 \%$ & 114321 & $57,7 \%$ & 130987 & $68,4 \%$ \\
\hline Other goods & 7 & $0,0 \%$ & 0 & $0,0 \%$ & 0 & $0,0 \%$ \\
\hline Other services & 1053 & $0,5 \%$ & 1080 & $0,5 \%$ & 1175 & $0,6 \%$ \\
\hline Total cost of revenues & 197789 & $90,4 \%$ & 169378 & $85,5 \%$ & 172634 & $90,1 \%$ \\
\hline \multicolumn{7}{|l|}{ Gross profit } \\
\hline Plant growing & 2691 & $1,2 \%$ & 2647 & $1,3 \%$ & -1649 & $-0,9 \%$ \\
\hline Animal breeding & 18688 & $8,5 \%$ & 26411 & $13,3 \%$ & 20948 & $10,9 \%$ \\
\hline Other goods & -1 & $0,0 \%$ & 0 & $0,0 \%$ & 0 & $0,0 \%$ \\
\hline Other services & -392 & $-0,2 \%$ & -442 & $-0,2 \%$ & -418 & $-0,2 \%$ \\
\hline Total gross profit & 20986 & $9,6 \%$ & 28616 & $14,5 \%$ & 18881 & $9,9 \%$ \\
\hline \multicolumn{7}{|l|}{ Other items } \\
\hline Interest income & 682 & $0,3 \%$ & 2805 & $1,4 \%$ & 5236 & $2,7 \%$ \\
\hline Interest expense & 0 & $0,0 \%$ & 0 & $0,0 \%$ & 0 & $0,0 \%$ \\
\hline Other incomes & 15684 & $7,2 \%$ & 9909 & $5,0 \%$ & 8320 & $4,3 \%$ \\
\hline Other expenses & 3268 & $1,5 \%$ & 7672 & $3,9 \%$ & 11575 & $6,0 \%$ \\
\hline Profit before income taxes & 34084 & $15,6 \%$ & 33658 & $17,0 \%$ & 20862 & $10,9 \%$ \\
\hline Other income (expense) & 1917 & $0,9 \%$ & 755 & $0,4 \%$ & 1075 & $0,6 \%$ \\
\hline Net profit & 32167 & $14,7 \%$ & 32903 & $16,6 \%$ & 19787 & $10,3 \%$ \\
\hline \multicolumn{7}{|l|}{ Additionally } \\
\hline Provision for Single Agricultural Tax & 1930 & $0,9 \%$ & 1974 & $1,0 \%$ & 1187 & $0,6 \%$ \\
\hline
\end{tabular}

Source: Author's own elaboration based on bookkeeping statement of JSC "Novoazovskoe" for 2013-2015.

All of the items in Income statement were compared with "Total revenues", because in this case we can see the structure of revenues and expenditures, and their influence on total income.

As we can see from the Table 8, the biggest part of "Total Revenues" in revenues' and cost's part takes the item "Animal breeding" - from $71,1 \%$ to $85,6 \%$ in revenues and more than $57,7 \%$ to $77,0 \%$ in costs each year. Then goes "Plant growing" - from $14,1 \%$ to $28,6 \%$ in revenues and from $12,9 \%$ to $27,3 \%$ in costs each year. In last 3 years, the item "Net profit" takes from $10,3 \%$ to $16,6 \%$ of "Total revenues".

In the section "Additionally" shows the Provision for a Single Agricultural Tax, that is used in Russian Federation for agricultural companies, and equal to $6 \%$ of "Net profit". 
Table 9. Year-to-year horizontal analysis of Income Statement of JSC "Novoazovskoe".

\begin{tabular}{|c|c|c|c|c|c|c|c|}
\hline \multirow{2}{*}{$\begin{array}{c}\text { In thousands of RUB } \\
\text { Name of item }\end{array}$} & \multicolumn{3}{|c|}{ Year } & \multicolumn{2}{|c|}{2014 to 2013} & \multicolumn{2}{|c|}{2015 to 2014} \\
\hline & 2013 & 2014 & 2015 & $\begin{array}{c}\text { In } \\
\text { amount }\end{array}$ & $\begin{array}{c}\% \text { of } \\
\text { previous }\end{array}$ & $\begin{array}{c}\text { In } \\
\text { amount }\end{array}$ & $\begin{array}{c}\% \text { of } \\
\text { previous }\end{array}$ \\
\hline \multicolumn{8}{|l|}{ Revenues } \\
\hline Plant growing & 30896 & 56624 & 38823 & 25728 & $183,3 \%$ & -17801 & $68,6 \%$ \\
\hline Animal breeding & 187212 & 140732 & 151935 & -46480 & $75,2 \%$ & 11203 & $108,0 \%$ \\
\hline Other goods & 6 & 0 & 0 & -6 & $0,0 \%$ & 0 & - \\
\hline Other services & 661 & 638 & 757 & -23 & $96,5 \%$ & 119 & $118,7 \%$ \\
\hline Total revenues & 218775 & 197994 & 191515 & -20781 & $90,5 \%$ & -6479 & $96,7 \%$ \\
\hline \multicolumn{8}{|l|}{ Cost of revenues } \\
\hline Plant growing & 28205 & 53977 & 40472 & 25772 & $191,4 \%$ & -13505 & $75,0 \%$ \\
\hline Animal breeding & 168524 & 114321 & 130987 & -54203 & $67,8 \%$ & 16666 & $114,6 \%$ \\
\hline Other goods & 7 & 0 & 0 & -7 & $0,0 \%$ & 0 & - \\
\hline Other services & 1053 & 1080 & 1175 & 27 & $102,6 \%$ & 95 & $108,8 \%$ \\
\hline Total cost of revenues & 197789 & 169378 & 172634 & -28411 & $85,6 \%$ & 3256 & $101,9 \%$ \\
\hline \multicolumn{8}{|l|}{ Gross profit } \\
\hline Plant growing & 2691 & 2647 & -1649 & -44 & $98,4 \%$ & -4296 & $-62,3 \%$ \\
\hline Animal breeding & 18688 & 26411 & 20948 & 7723 & $141,3 \%$ & -5463 & $79,3 \%$ \\
\hline Other goods & -1 & 0 & 0 & 1 & - & 0 & - \\
\hline Other services & -392 & -442 & -418 & -50 & - & 24 & - \\
\hline Total gross profit & 20986 & 28616 & 18881 & 7630 & $136,4 \%$ & -9735 & $66,0 \%$ \\
\hline \multicolumn{8}{|l|}{ Other items } \\
\hline Interest income & 682 & 2805 & 5236 & 2123 & $411,3 \%$ & 2431 & $186,7 \%$ \\
\hline Interest expense & 0 & 0 & 0 & 0 & $0,0 \%$ & 0 & $0,0 \%$ \\
\hline Other incomes & 15684 & 9909 & 8320 & -5775 & $63,2 \%$ & -1589 & $84,0 \%$ \\
\hline Other expenses & 3268 & 7672 & 11575 & 4404 & $234,8 \%$ & 3903 & $150,9 \%$ \\
\hline Profit before income taxes & 34084 & 33658 & 20862 & -426 & $98,8 \%$ & -12796 & $62,0 \%$ \\
\hline Other income (expense), net & 1917 & 755 & 1075 & -1162 & - & 320 & - \\
\hline Net profit & 32167 & 32903 & 19787 & 736 & $102,3 \%$ & -13116 & $60,1 \%$ \\
\hline \multicolumn{8}{|l|}{ Additionally } \\
\hline $\begin{array}{l}\text { Provision for Single Agricultural } \\
\text { Tax }\end{array}$ & 1930 & 1974 & 1187 & 44 & $102,3 \%$ & -787 & $60,1 \%$ \\
\hline
\end{tabular}

Source: Author's own elaboration based on bookkeeping statement of JSC “Novoazovskoe" for 2013-2015.

As we can see from the Table 9 Total Revenues decreased on almost $27 \mathrm{mln}$ rubles from 2013 to 2015. The biggest part of it - is a decline in income from Animal breeding - over $35 \mathrm{mln}$ rubles. In "Total gross profit" section we also can see, that Plant growing declined on more than 4,3 mln rubles from 2013 to 2015, and Total gross profit declined on more than 2,1 mln rubles from 2013 to 2015.

Provision for a Single Agricultural Tax was also decreased on more than 743 thousand rubles from 2013 to 2015 . More graphically it's on the Figure 10. 


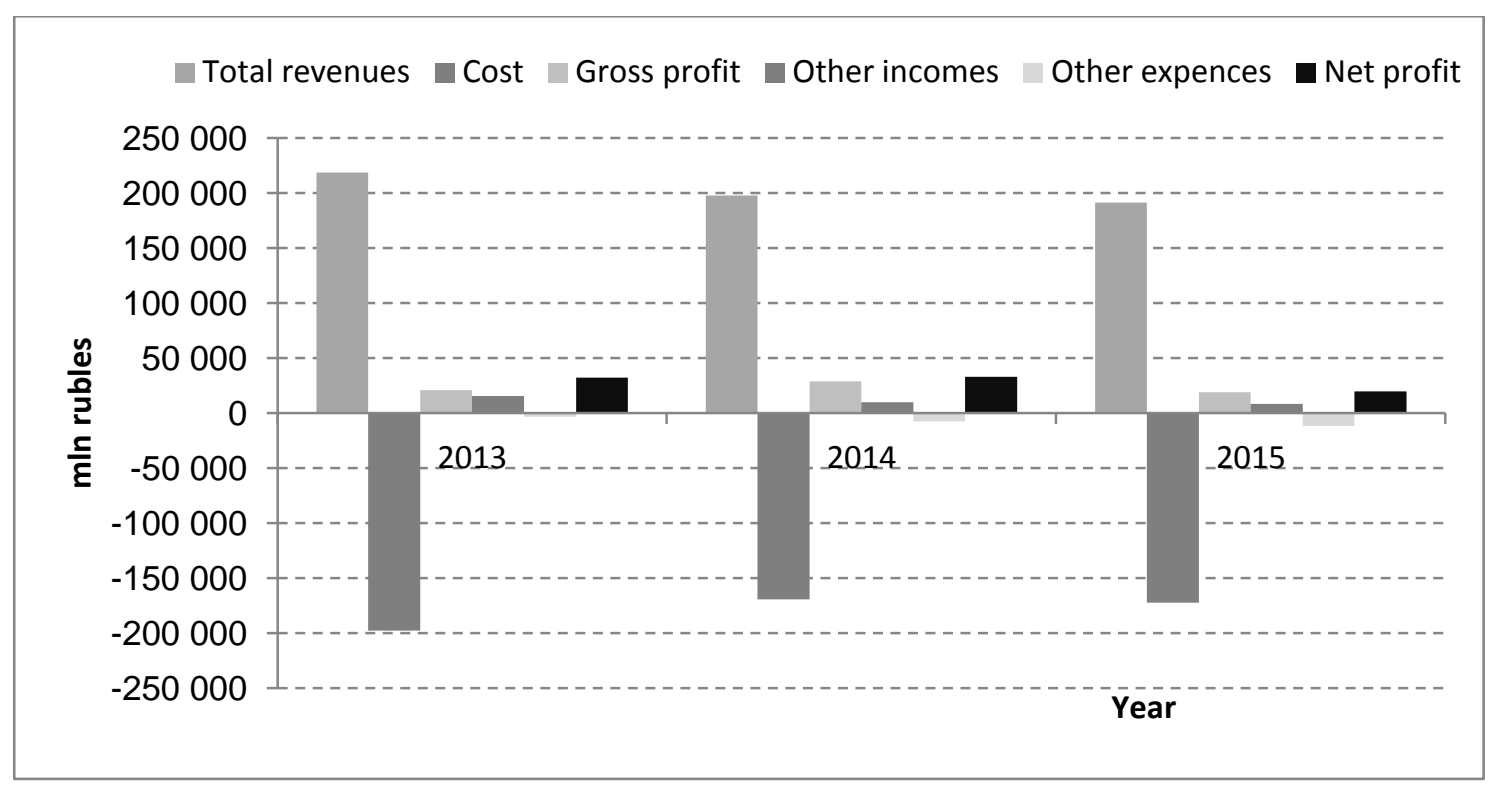

Figure 10. Dynamic in changes of Income statement results.

Source: Author's own elaboration based on bookkeeping statement of JSC "Novoazovskoe" for 2013-2015.

Next step of analysis of business activity and state of an enterprise, need to analyse its current assets. Firstly, we will start with analyzing of lands' composition and structure.

For inspection of square and quality of lands, it's necessary to make the analysis of its structure and composition for last 3 years. Data obtained from accounting statements, and presented in the Table 10 with both analysis - horizontal year-to-year, year-to-base and vertical ones.

Table 10. Composition and structure of lands of JSC "Novoazovskoe" for 2013-2015.

\begin{tabular}{|c|c|c|c|c|c|c|c|c|c|c|c|c|}
\hline \multirow{3}{*}{ Kind of land } & \multicolumn{12}{|c|}{ Years } \\
\hline & \multicolumn{2}{|c|}{2013} & \multicolumn{2}{|c|}{2014} & \multicolumn{2}{|c|}{2015} & \multicolumn{2}{|c|}{$\begin{array}{c}2014 \text { to } \\
2013 \\
\end{array}$} & \multicolumn{2}{|c|}{$\begin{array}{c}2015 \text { to } \\
2014 \\
\end{array}$} & \multicolumn{2}{|c|}{$\begin{array}{c}2015 \text { to } \\
2013 \\
\end{array}$} \\
\hline & $\begin{array}{l}\text { Sq, } \\
\text { ha }\end{array}$ & $\begin{array}{c}\text { To } \\
\text { total, } \\
\% \\
\end{array}$ & $\begin{array}{l}\text { Sq, } \\
\text { ha }\end{array}$ & $\begin{array}{c}\text { To } \\
\text { total, } \\
\% \\
\end{array}$ & $\begin{array}{l}\text { Sq, } \\
\text { ha }\end{array}$ & $\begin{array}{c}\text { To } \\
\text { total, } \\
\% \\
\end{array}$ & $\begin{array}{l}\text { In } \\
\text { ha }\end{array}$ & In \% & $\begin{array}{l}\text { In } \\
\text { ha }\end{array}$ & In \% & $\begin{array}{l}\text { In } \\
\text { ha }\end{array}$ & $\ln \%$ \\
\hline $\begin{array}{l}\text { Total square of } \\
\text { lands: }\end{array}$ & 11118 & 100,0 & 11118 & 100,0 & 11200 & 100,0 & 0 & 100 & 82 & 101 & 82 & 101 \\
\hline Agricultural lands: & 11118 & 100,0 & 11118 & 100,0 & 11200 & 100,0 & 0 & 100 & 82 & 101 & 82 & 101 \\
\hline Arable & 11118 & 100,0 & 11118 & 100,0 & 11200 & 100,0 & 0 & 100 & 82 & 101 & 82 & 101 \\
\hline $\begin{array}{c}\text { Type of ownership: } \\
\text { In ownership }\end{array}$ & 0 & 0,0 & 0 & 0,0 & 0 & 0,0 & 0 & - & 0 & - & 0 & - \\
\hline Renting & 11118 & 100,0 & 11118 & 100,0 & 11200 & 100,0 & 0 & 100 & 82 & 101 & 82 & 101 \\
\hline $\begin{array}{c}\text { By usage in } \\
\text { production: } \\
\text { Used }\end{array}$ & 10080 & 90,7 & 10031 & 90,2 & 9960 & 88,9 & -49 & 100 & -120 & 99 & -71 & 99 \\
\hline Not used & 1038 & 9,3 & 1087 & 9,8 & 1240 & 11,1 & 49 & - & 202 & - & 153 & 114 \\
\hline
\end{tabular}

Source: Author's own elaboration based on bookkeeping statement of JSC "Novoazovskoe" for 2013-2015.

Results of both analyses are more graphically presented on the Figure 11. 


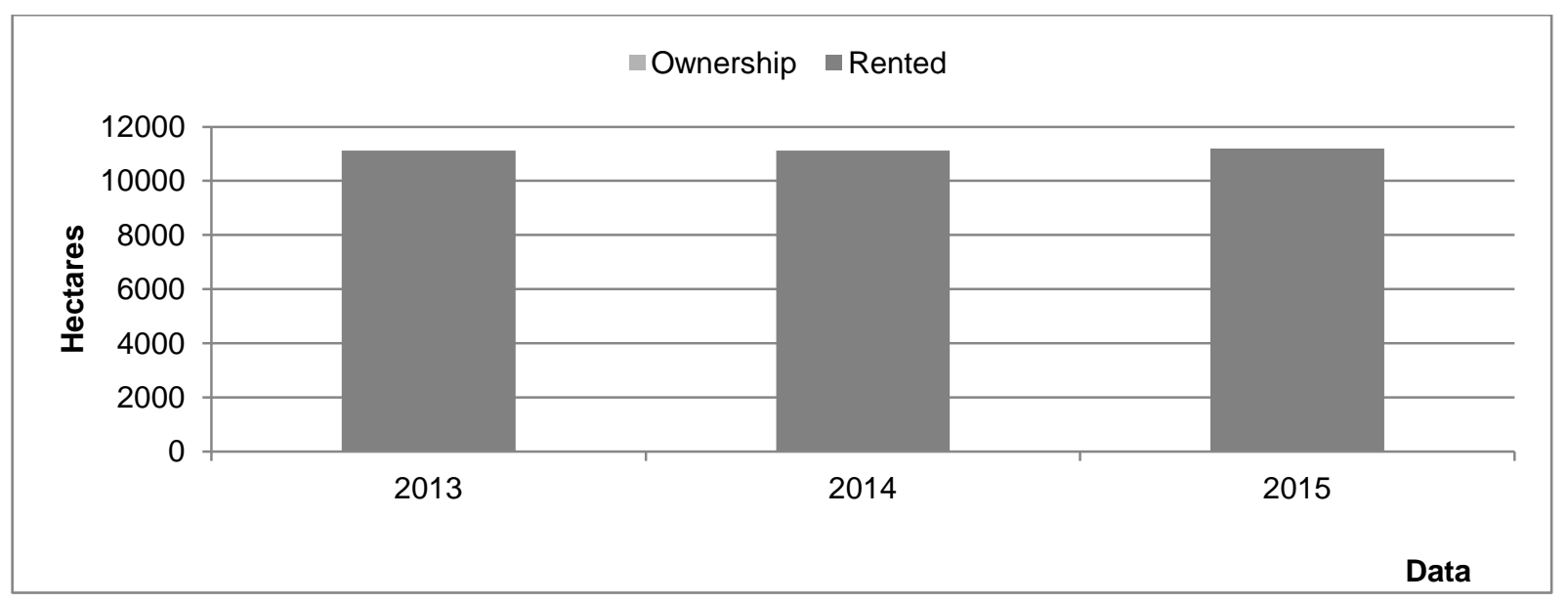

Figure 11. Result of vertical and horizontal analyses of lands' structure.

Source: Author's own elaboration based on bookkeeping statement of JSC "Novoazovskoe" for 2013-2015.

Horizontal analysis shows, that there is a small positive trend of square of lands increase. Total square was increased from 11118 ha in 2013 to 11200 ha in 2015 - on 82 hectares (less than $1 \%$ ). Vertical analysis (structural analysis) shows us, that there are no changes in the structure of agricultural lands $-100 \%$ of arable for 3 years. By the way, there are no changes in the type of ownership of lands: during all 3 years all of the lands were rented.

Secondly, need to determine the presence of means of production (combines, tractors, etc.) and its dynamic of changing for 3 last years.

Table 11. Composition and structure of means of production in JSC "Novoazovskoe" in 2013-2015.

\begin{tabular}{|c|c|c|c|c|c|c|c|c|c|}
\hline \multirow{2}{*}{ Kind of mean of production } & \multicolumn{3}{|c|}{ Year } & \multicolumn{2}{|c|}{2014 to 2013} & \multicolumn{2}{|c|}{2015 to 2014} & \multicolumn{2}{|c|}{2015 to 2013} \\
\hline & 2013 & 2014 & 2015 & In units & $\ln \%$ & In units & $\ln \%$ & In units & $\ln \%$ \\
\hline Machineries & 305 & 197 & 182 & -108 & $65 \%$ & -15 & $92 \%$ & -123 & $60 \%$ \\
\hline Tractors of all marks & 50 & 49 & 46 & -1 & $98 \%$ & -3 & $94 \%$ & -4 & $92 \%$ \\
\hline Tractors trailers & 34 & 31 & 25 & -3 & $91 \%$ & -6 & $81 \%$ & -9 & $74 \%$ \\
\hline $\begin{array}{l}\text { Seeders and sowing } \\
\text { machines }\end{array}$ & 86 & 23 & 23 & -63 & $27 \%$ & 0 & $100 \%$ & -63 & $27 \%$ \\
\hline Tractor-drawn haymowers & 13 & 11 & 11 & -2 & $85 \%$ & 0 & $100 \%$ & -2 & $85 \%$ \\
\hline Combines & 28 & 25 & 18 & -3 & $89 \%$ & -7 & $72 \%$ & -10 & $64 \%$ \\
\hline Combine harvesters & 8 & 5 & 4 & -3 & $63 \%$ & -1 & $80 \%$ & -4 & $50 \%$ \\
\hline Grain combine & 20 & 20 & 14 & 0 & $100 \%$ & -6 & $70 \%$ & -6 & $70 \%$ \\
\hline Mounted reapers & 30 & 20 & 19 & -10 & $67 \%$ & -1 & $95 \%$ & -11 & $63 \%$ \\
\hline Mlking parlors and agregates & 10 & 10 & 10 & 0 & $100 \%$ & 0 & $100 \%$ & 0 & $100 \%$ \\
\hline Feed dispensers and mixers & 6 & 6 & 7 & 0 & $100 \%$ & 1 & $117 \%$ & 1 & $117 \%$ \\
\hline $\begin{array}{l}\text { Transporters for dung } \\
\text { disposal }\end{array}$ & 43 & 19 & 20 & -24 & $44 \%$ & 1 & $105 \%$ & -23 & $47 \%$ \\
\hline Tractor rake & 4 & 2 & 2 & -2 & $50 \%$ & 0 & $100 \%$ & -2 & $50 \%$ \\
\hline Pickup-baler & 1 & 1 & 1 & 0 & $100 \%$ & 0 & $100 \%$ & 0 & $100 \%$ \\
\hline Transport vehicles & 34 & 34 & 25 & 0 & $100 \%$ & -9 & $74 \%$ & -9 & $74 \%$ \\
\hline $\begin{array}{l}\text { Total number of means of } \\
\text { production }\end{array}$ & 339 & 231 & 207 & -108 & $68 \%$ & -24 & $90 \%$ & -132 & $61 \%$ \\
\hline Cost of mean of productic & in thous & nds rubl & & In RUB & In \% & In RUB & In \% & In RUB & In \% \\
\hline Machineries & 82676 & 98570 & 90925 & 15894 & $119 \%$ & -7645 & $92 \%$ & 8249 & $110 \%$ \\
\hline Transport vehicles & 8501 & 8440 & 9161 & -61 & $99 \%$ & 721 & $109 \%$ & 660 & $108 \%$ \\
\hline Total cost & 91177 & 107010 & 100086 & 15833 & $117 \%$ & -6924 & $94 \%$ & 8909 & $110 \%$ \\
\hline
\end{tabular}

Source: Author's own elaboration based on bookkeeping statement of JSC "Novoazovskoe" for 2013-2015. 
As we can see in the Table 11, total number of Machineries and Transport vehicles decreased from 2013 to 2015 on 123 and 9 units accordingly. Total cost of all machineries and transport vehicles increased on more than $8,9 \mathrm{mln}$ rubles (10\%) from 2013 to 2015.

Because JSC "Novoazovskoe" produces milk, further need to inspect the number of animals employed.

Table 12. Number of animals employed and their cost in JSC "Novoazovskoe" for 2013-2015.

\begin{tabular}{|c|c|c|c|c|c|c|c|c|c|}
\hline Parameter & 2013 & 2014 & 2015 & \multicolumn{2}{|c|}{2014 to 2013} & \multicolumn{2}{|c|}{2015 to 2014} & \multicolumn{2}{|c|}{2015 to 2013} \\
\hline \multicolumn{10}{|c|}{ Number of animals (in units) } \\
\hline $\begin{array}{l}\text { Name of } \\
\text { animals }\end{array}$ & Units & Units & Units & In units & In \% & In units & $\ln \%$ & In units & $\ln \%$ \\
\hline Cattle & 2668 & 2641 & 2660 & -27 & $99,0 \%$ & 19 & $100,7 \%$ & -8 & $100 \%$ \\
\hline cows & 1023 & 1023 & 1023 & 0 & $100,0 \%$ & 0 & $100,0 \%$ & 0 & $100 \%$ \\
\hline cows & 1023 & 1023 & 1023 & 0 & $100,0 \%$ & 0 & $100,0 \%$ & 0 & $100 \%$ \\
\hline heifer unbred & 186 & 113 & 134 & -73 & $60,8 \%$ & 21 & $118,6 \%$ & -52 & $72 \%$ \\
\hline Horses & 13 & 12 & 11 & -1 & $92,3 \%$ & -1 & $91,7 \%$ & -2 & $85 \%$ \\
\hline $\begin{array}{l}\text { breeding mare } \\
\text { 3-year and more }\end{array}$ & 4 & 4 & 2 & 0 & $100,0 \%$ & -2 & $50,0 \%$ & -2 & $50 \%$ \\
\hline gelded horses & 7 & 5 & 6 & -2 & $71,4 \%$ & 1 & $120,0 \%$ & -1 & $86 \%$ \\
\hline \multicolumn{10}{|c|}{ Cost of animals (thousands of rubles - RUB) } \\
\hline $\begin{array}{l}\text { Name of } \\
\text { animals }\end{array}$ & Cost & Cost & Cost & In RUB & In \% & In RUB & $\ln \%$ & In RUB & $\ln \%$ \\
\hline Cattle & 88060 & 94473 & 104335 & 6413 & $107,3 \%$ & 9862 & $110,4 \%$ & 16275 & $118 \%$ \\
\hline cows & 47821 & 52695 & 58102 & 4874 & $110,2 \%$ & 5407 & $110,3 \%$ & 10281 & $121 \%$ \\
\hline milking cows & 47821 & 52695 & 58102 & 4874 & $110,2 \%$ & 5407 & $110,3 \%$ & 10281 & $121 \%$ \\
\hline heifer unbred & 8277 & 6422 & 7911 & -1855 & $77,6 \%$ & 1489 & $123,2 \%$ & -366 & $96 \%$ \\
\hline Horses & 528 & 656 & 783 & 128 & $124,2 \%$ & 127 & $119,4 \%$ & 255 & $148 \%$ \\
\hline $\begin{array}{l}\text { breeding mare } \\
\text { 3-year and more }\end{array}$ & 93 & 125 & 63 & 32 & $134,4 \%$ & -62 & $50,4 \%$ & -30 & $68 \%$ \\
\hline gelded horses & 314 & 225 & 331 & -89 & $71,7 \%$ & 106 & $147,1 \%$ & 17 & $105 \%$ \\
\hline Total cost & 88588 & 95129 & 105118 & 14466 & - & 22336 & - & 36696 & - \\
\hline
\end{tabular}

Source: Author's own elaboration based on bookkeeping statement of JSC "Novoazovskoe" for 2013-2015.

As we can see in the Table 12, the number of milking cows (the most important part of milk production) stays same for last 3 years. The reason for that is to keep the number of milking cows on the same level - 1023 is because the milking parlors were designed for containing of this amount of cows. Total decline of number of cattle is 8 units $(0,3 \%)$, but the growth of the price is $16,275 \mathrm{mln}$ rubles $(118 \%)$.

For further, analysis of an enterprise need to analyse the labor resources of JSC "Novoazovskoe". Initial data and horizontal analysis are in the Table 13. 
Table 13. Average number of employees in JSC "Novoazovskoe" for 2013-2015.

\begin{tabular}{|c|c|c|c|c|c|c|c|c|c|}
\hline \multirow[t]{2}{*}{ Parameter } & \multirow{2}{*}{\multicolumn{7}{|c|}{$\begin{array}{cc}2015 & 2014 \text { to } 2013 \\
\text { Number of employees }\end{array}$}} & \multicolumn{2}{|c|}{2015 to 2013} \\
\hline & & & & & & & & & \\
\hline Type of employees & In units & In units & In units & In units & $\ln \%$ & In units & $\ln \%$ & In units & $\ln \%$ \\
\hline Employees - total & 294 & 237 & 235 & -57 & $80,6 \%$ & -2 & $99,2 \%$ & -59 & $79,9 \%$ \\
\hline $\begin{array}{l}\text { Employees in major } \\
\text { production }\end{array}$ & 277 & 221 & 211 & -56 & $79,8 \%$ & -10 & $95,5 \%$ & -66 & $76,2 \%$ \\
\hline Regular employees & 241 & 183 & 174 & -58 & $75,9 \%$ & -9 & $95,1 \%$ & -67 & $72,2 \%$ \\
\hline tractor-drivers & 29 & 29 & 27 & 0 & $100,0 \%$ & -2 & $93,1 \%$ & -2 & $93,1 \%$ \\
\hline $\begin{array}{l}\text { milking | } \\
\text { operators }\end{array}$ & 29 & 32 & 30 & 3 & $110,3 \%$ & -2 & $93,8 \%$ & 1 & $103,4 \%$ \\
\hline cattleman & 27 & 23 & 24 & -4 & $85,2 \%$ & 1 & $104,3 \%$ & -3 & $88,9 \%$ \\
\hline pigs keepers & 35 & 0 & 0 & -35 & $0,0 \%$ & 0 & - & -35 & - \\
\hline Seasonal employees & 3 & 8 & 9 & 5 & $266,7 \%$ & 1 & $112,5 \%$ & 6 & $300,0 \%$ \\
\hline Officers & 33 & 30 & 28 & -3 & $90,9 \%$ & -2 & $93,3 \%$ & -5 & $84,8 \%$ \\
\hline managers & 12 & 12 & 11 & 0 & $100,0 \%$ & -1 & $91,7 \%$ & -1 & $91,7 \%$ \\
\hline specialists & 18 & 15 & 14 & -3 & $83,3 \%$ & -1 & $93,3 \%$ & -4 & $77,8 \%$ \\
\hline $\begin{array}{l}\text { Employees in other } \\
\text { productions }\end{array}$ & 14 & 13 & 14 & -1 & $92,9 \%$ & 1 & $107,7 \%$ & 0 & $100,0 \%$ \\
\hline Retail managers & 3 & 3 & 3 & 0 & $100,0 \%$ & 0 & $100,0 \%$ & 0 & $100,0 \%$ \\
\hline Construction employees & 0 & 0 & 7 & 0 & - & 7 & - & 7 & - \\
\hline \multicolumn{10}{|c|}{ Salary of employees (thousands of rubles - RUB) } \\
\hline Type of employees & Salary & Salary & Salary & In RUB & $\ln \%$ & In RUB & $\ln \%$ & In RUB & $\ln \%$ \\
\hline Employees - total & 68924 & 70346 & 73336 & 1422 & $102,1 \%$ & 2990 & $104,3 \%$ & 4412 & $106,4 \%$ \\
\hline $\begin{array}{l}\text { Employees in major } \\
\text { production }\end{array}$ & 64664 & 65518 & 67598 & 854 & $101,3 \%$ & 2080 & $103,2 \%$ & 2934 & $104,5 \%$ \\
\hline Regular employees & 52775 & 50413 & 53525 & -2362 & $95,5 \%$ & 3112 & $106,2 \%$ & 750 & $101,4 \%$ \\
\hline tractor-drivers & 8157 & 9952 & 10186 & 1795 & $122,0 \%$ & 234 & $102,4 \%$ & 2029 & $124,9 \%$ \\
\hline $\begin{array}{l}\text { milking parlors' } \\
\text { operators }\end{array}$ & 6676 & 7545 & 8581 & 869 & $113,0 \%$ & 1036 & $113,7 \%$ & 1905 & $128,5 \%$ \\
\hline cattleman & 5354 & 6564 & 7162 & 1210 & $122,6 \%$ & 598 & $109,1 \%$ & 1808 & $133,8 \%$ \\
\hline pigs keepers & 8557 & 0 & 0 & -8557 & $0,0 \%$ & 0 & - & -8557 & $0,0 \%$ \\
\hline Seasonal employees & 408 & 2624 & 2028 & 2216 & $643,1 \%$ & -596 & $77,3 \%$ & 1620 & $497,1 \%$ \\
\hline Officers & 11481 & 12481 & 12045 & 1000 & $108,7 \%$ & -436 & $96,5 \%$ & 564 & $104,9 \%$ \\
\hline managers & 6264 & 7102 & 7156 & 838 & $113,4 \%$ & 54 & $100,8 \%$ & 892 & $114,2 \%$ \\
\hline specialists & 4382 & 4511 & 4889 & 129 & $102,9 \%$ & 378 & $108,4 \%$ & 507 & $111,6 \%$ \\
\hline $\begin{array}{l}\text { Employees in other } \\
\text { productions }\end{array}$ & 3789 & 4281 & 3873 & 492 & $113,0 \%$ & -408 & $90,5 \%$ & 84 & $102,2 \%$ \\
\hline Retail managers & 471 & 547 & 578 & 76 & $116,1 \%$ & 31 & $105,7 \%$ & 107 & $122,7 \%$ \\
\hline Construction employees & 0 & 0 & 1287 & 0 & - & 1287 & - & 1287 & \\
\hline
\end{tabular}

Source: Author's own elaboration based on bookkeeping statement of JSC "Novoazovskoe" for 2013-2015.

As we can see from the Table 13, the total number of employees was decreased on 59 units $(20,1 \%)$ for last 3 years, because of elimination of pigs' production. Total amount of salary increased on more than 4,41 mln rubles (106,4\%) from 2013 to 2015.

For analysis of composition and structure of revenues from sale of production need to make an inspection of statements with specified data - Form 9 and Form 13 of bookkeeping statement. Initial data of plant production and horizontal analysis are in the Tables 14 and 15. 
Table 14. Composition and structure of sold plant production in JSC "Novoazovskoe" for 2013-2015.

\begin{tabular}{|c|c|c|c|c|c|c|c|c|c|}
\hline Parameter & 2013 & 2014 & 2015 & \multicolumn{2}{|c|}{2014 to 2013} & \multicolumn{2}{|c|}{2015 to 2014} & \multicolumn{2}{|c|}{2015 to 2013} \\
\hline \multicolumn{10}{|c|}{ Weight of cereals, in centners $(100 \mathrm{~kg})$} \\
\hline Type of cereal & Weight & Weight & Weight & $\begin{array}{c}\text { In } \\
100 \mathrm{~kg} \\
\end{array}$ & $\ln \%$ & $\begin{array}{c}\text { In } \\
100 \mathrm{~kg}\end{array}$ & $\ln \%$ & $\begin{array}{c}\text { In } \\
100 \mathrm{~kg}\end{array}$ & $\ln \%$ \\
\hline Cereals - total & 47945 & 87103 & 52901 & 39158 & $181,7 \%$ & -34202 & $60,7 \%$ & 4956 & $110,3 \%$ \\
\hline Wheat & 30126 & 68809 & 28285 & 38683 & $228,4 \%$ & -40524 & $41,1 \%$ & -1841 & $93,9 \%$ \\
\hline Barley & 15319 & 16788 & 18117 & 1469 & $109,6 \%$ & 1329 & $107,9 \%$ & 2798 & $118,3 \%$ \\
\hline Peas & 2500 & 340 & 6499 & -2160 & $13,6 \%$ & 6159 & $1911,5 \%$ & 3999 & $260,0 \%$ \\
\hline Oat & 0 & 1166 & 0 & 1166 & - & -1166 & - & 0 & - \\
\hline Rapeseed & 5265 & 7040 & 824 & 1775 & $133,7 \%$ & -6216 & $11,7 \%$ & -4441 & $15,7 \%$ \\
\hline Other plant production & $x^{*}$ & $x$ & $x$ & - & - & - & - & - & - \\
\hline \multicolumn{10}{|c|}{ Revenues from plant production (thousands of rubles - RUB) } \\
\hline Type of cereal & Income & Income & Income & In RUB & $\ln \%$ & In RUB & $\ln \%$ & In RUB & $\ln \%$ \\
\hline Cereals - total & 22333 & 48765 & 36365 & 26432 & $218,4 \%$ & -12400 & $74,6 \%$ & 14032 & $162,8 \%$ \\
\hline Wheat & 15921 & 40856 & 18862 & 24935 & $256,6 \%$ & -21994 & $46,2 \%$ & 2941 & $118,5 \%$ \\
\hline Barley & 4912 & 7137 & 10036 & 2225 & $145,3 \%$ & 2899 & $140,6 \%$ & 5124 & $204,3 \%$ \\
\hline Peas & 1500 & 306 & 7467 & -1194 & $20,4 \%$ & 7161 & $2440,2 \%$ & 5967 & $497,8 \%$ \\
\hline Oat & 0 & 466 & 0 & 466 & - & -466 & - & 0 & - \\
\hline Rapeseed & 4486 & 7428 & 1904 & 2942 & $165,6 \%$ & -5524 & $25,6 \%$ & -2582 & $42,4 \%$ \\
\hline Other plant production & 4077 & 431 & 554 & -3646 & $10,6 \%$ & 123 & $128,5 \%$ & -3523 & $13,6 \%$ \\
\hline $\begin{array}{c}\text { Plant production } \\
\text { revenues }\end{array}$ & 30896 & 56624 & 38823 & 25728 & $183,3 \%$ & -17801 & $68,6 \%$ & 7927 & $125,7 \%$ \\
\hline
\end{tabular}

Source: Author's own elaboration based on bookkeeping statement of JSC "Novoazovskoe" for 2013-2015.

As we can see from the Table 14, total ya ield production of cereals increased on 4956 centners $(110,3 \%)$, and in cash equivalent the growth was $14,03 \mathrm{mln}$ rubles (162,8\%) from 2013 to 2015, accordingly. Especially, the most impressive results showed production of peas - 3999 centners $(260,0 \%)$ and 5,967 mln rubles (497,8\%) in cash equivalent from 2013 to 2015.

Total plant production revenues increased on 7,927 mln rubles (125,7\%) from 2013 to 2015, and has the positive trend. But, also from the composition of plant production and sales, disappeared the oat. It explains with the decision of managers of a company do not sale this type of cereal on the market.

Initial data for animal breeding and horizontal analysis are in the Table 15.

\footnotetext{
* Not applicable for calculation in one measure.
} 
Table 15. Composition of livestock production in JSC "Novoazovskoe" for 2013-2015.

\begin{tabular}{|c|c|c|c|c|c|c|c|c|c|}
\hline Parameter & 2013 & 2014 & 2015 & \multicolumn{2}{|c|}{2014 to 2013} & \multicolumn{2}{|c|}{2015 to 2014} & \multicolumn{2}{|c|}{2015 to 2013} \\
\hline \multicolumn{10}{|c|}{ Weight of livestock, in centners (100kg) } \\
\hline Type of livestock & Weight & Weight & Weight & $\begin{array}{c}\ln \\
100 \mathrm{~kg}\end{array}$ & In \% & $\begin{array}{c}\text { In } \\
100 \mathrm{~kg}\end{array}$ & $\ln \%$ & $\begin{array}{c}\ln \\
100 \mathrm{~kg}\end{array}$ & $\ln \%$ \\
\hline Livestock - total & 15039 & 3802 & 3536 & -11237 & $25,3 \%$ & -266 & $93,0 \%$ & -11503 & $23,5 \%$ \\
\hline cattle & 2989 & 3798 & 3536 & 809 & $127,1 \%$ & -262 & $93,1 \%$ & 547 & $118,3 \%$ \\
\hline horses & 0 & 4 & 0 & 4 & - & -4 & - & 0 & - \\
\hline pigs & 12050 & 0 & 0 & -12050 & $0,0 \%$ & 0 & - & -12050 & - \\
\hline Milk & 48707 & 50625 & 54272 & 1918 & $103,9 \%$ & 3647 & $107,2 \%$ & 5565 & $111,4 \%$ \\
\hline $\begin{array}{l}\text { Livestock processed } \\
\text { production }\end{array}$ & $X^{*}$ & $x$ & $x$ & - & - & - & - & - & - \\
\hline \multicolumn{10}{|c|}{ Revenues from livestock (thousands of rubles - RUB) } \\
\hline Type of livestock & Income & Income & Income & In RUB & In \% & In RUB & $\ln \%$ & In RUB & $\ln \%$ \\
\hline Livestock - total & 98625 & 27355 & 31787 & -71270 & $27,7 \%$ & 4432 & $116,2 \%$ & -66838 & $32,2 \%$ \\
\hline cattle & 20689 & 27335 & 31787 & 6646 & $132,1 \%$ & 4452 & $116,3 \%$ & 11098 & $153,6 \%$ \\
\hline horses & 0 & 20 & 0 & 20 & - & -20 & - & 0 & - \\
\hline pigs & 77936 & 0 & 0 & -77936 & $0,0 \%$ & 0 & - & -77936 & - \\
\hline Milk & 87670 & 113212 & 119495 & 25542 & $129,1 \%$ & 6283 & $105,5 \%$ & 31825 & $136,3 \%$ \\
\hline $\begin{array}{l}\text { Livestock processed } \\
\text { production }\end{array}$ & 917 & 165 & 653 & -752 & $18,0 \%$ & 488 & $395,8 \%$ & -264 & $71,2 \%$ \\
\hline Livestock revenues & 187212 & 140732 & 151935 & -46480 & $75,2 \%$ & 11203 & $108,0 \%$ & -35277 & $81,2 \%$ \\
\hline
\end{tabular}

Source: Author's own elaboration based on bookkeeping statement of JSC "Novoazovskoe" for 2013-2015.

As we can see from the table 15, total weight of sold meat production decreased on 11503 centners (76,5\%): from 15039 centners in 2013 to 3536 centners in 2015. In monetary terms decreased on 66838 thousand rubles (67,8\%): from 98625 thousand rubles in 2013 to 31787 thousand rubles in 2015.

Volume of milk sold increased on 5565 centners (111,4\%): from 48707 centners in 2013 to 54272 centners in 2015. In monetary terms increased on 31825 thousand rubles (136,3\%): from 87670 thousand rubles in 2013 to 119495 thousand rubles in 2015 .

For more detailed analysis of enterprise's efficiency necessary to consider such indicators as production yield per one hectare and average milk yield per one cow. In the Table 16 is presented the calculation of an average milk yield, and yield of cereals and legumes from one hectare.

Based on the data of Table 16, we can say that mostly all kinds of production have negative trends. Also, based on all data mentioned above, we can say that JSC "Novoazovskoe" has the negative trend of business activity. We think that this situation happened because of total unstable economic situation in Russian Federation. Also, the reasons to decline the production are insects-pest, fires, unfavorable weather conditions, unscrupulous competitors.

\footnotetext{
* Not applicable for calculation in one measure.
} 
Table 16. Production results of specified kind of productions in JSC "Novoazovskoe" for 2013-2015.

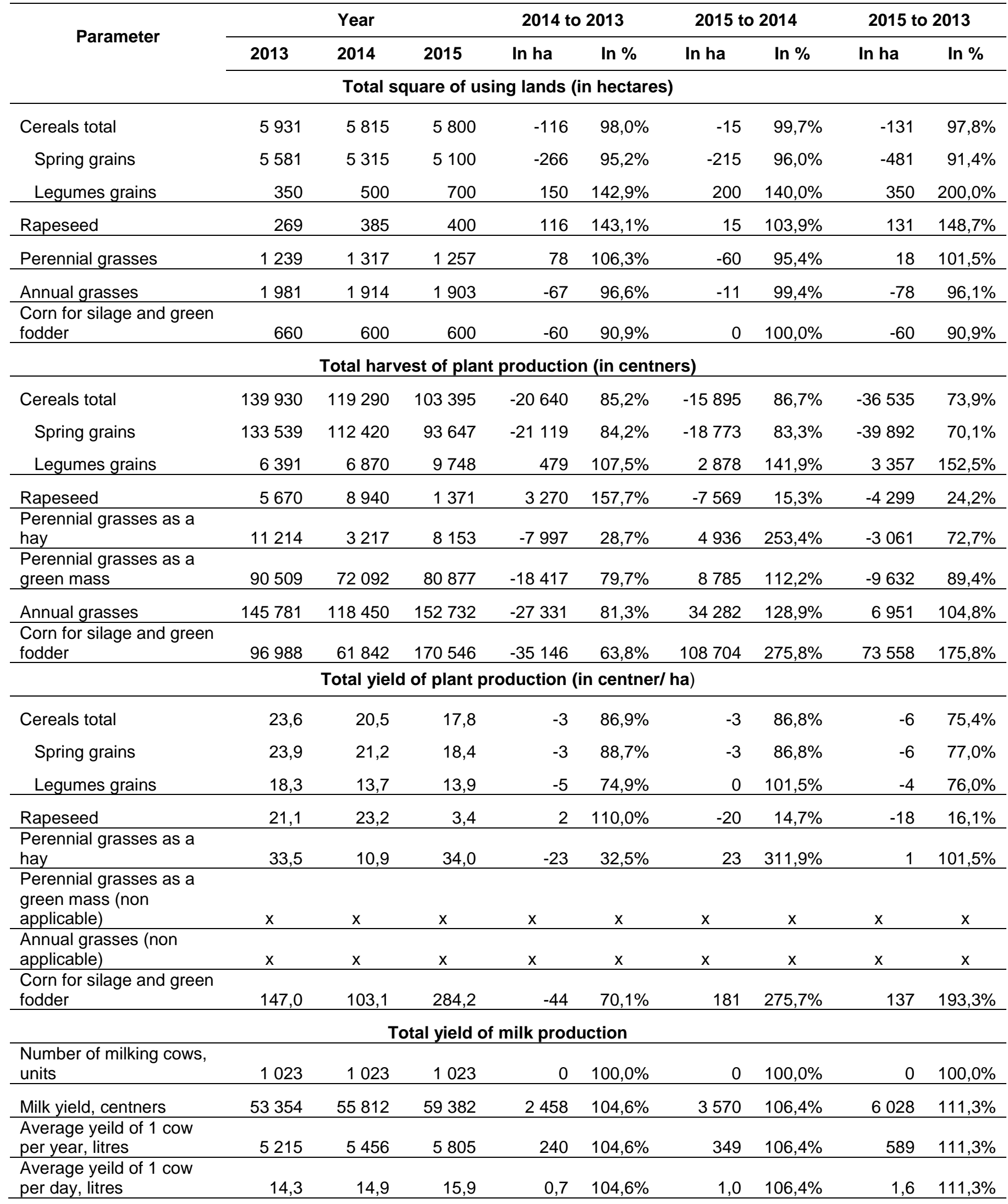

Source: Author's own elaboration based on bookkeeping statement of JSC "Novoazovskoe" for 2013-2015. 


\subsection{Evaluation of financial-economic status of JSC "Novoazovskoe"}

Based on the analysis of balance sheets, income statements and other forms of statement it is necessary to examine the financial ratios of an enterprise for last 3 years. Evaluation of financialeconomic will be implemented according to the following ratios:

- General ratios;

- Liquidity ratios;

- Profitability indicator ratios;

- Operating performance ratios;

- Turnover ratios.

Results of examination are presented in the Tables 17-21. (Horngren, Harrison, \& Oliver, 2012)

Table 17. General financial ratios for 2013-2015, in thousand rubles.

\begin{tabular}{lcrr}
\hline \multicolumn{1}{c}{ General financial ratios } & $\mathbf{2 0 1 3}$ & $\mathbf{2 0 1 4}$ & \multicolumn{1}{c}{$\mathbf{2 0 1 5}$} \\
\hline EBIT & 34084 & 33658 & 20862 \\
\hline EBT & 20986 & 28616 & 18881 \\
\hline Net (working) assets & 183521 & 188285 & 188613 \\
\hline
\end{tabular}

Source: Author's own elaboration based on bookkeeping statement of JSC "Novoazovskoe" for 2013-2015.

Based on results of Table 17, we can see that EBIT and EBT have the positive values, which means that enterprise generates profit.

Table 18. Liquidity ratios for 2013-2015.

\begin{tabular}{|c|c|c|c|}
\hline Liquidity Ratios & 2013 & 2014 & 2015 \\
\hline Current ratio & 202,89 & 442,98 & 50,26 \\
\hline Quick ratio & 64,62 & 136,67 & 11,83 \\
\hline Capital flexibility ratio & 201,89 & 441,98 & 49,26 \\
\hline
\end{tabular}

Source: Author's own elaboration based on bookkeeping statement of JSC "Novoazovskoe" for 2013-2015.

Based on results of Table 18, we can see that current liquidity ratio in 2015 is equal to 50,26 which means, that company can easily cover all of the debt.

Table 19. Operating performance ratios for 2013-2015.

\begin{tabular}{lrrr}
\hline \multicolumn{1}{c}{ Operating Performance Ratios } & \multicolumn{1}{c}{$\mathbf{2 0 1 3}$} & \multicolumn{1}{c}{$\mathbf{2 0 1 4}$} & \multicolumn{1}{c}{$\mathbf{2 0 1 5}$} \\
\hline Revenues per employee & 875,10 & 795,16 & 769,14 \\
\hline Fixed assets per employee & 540,45 & 605,36 & 643,15 \\
\hline Revenue on fixed assets & 3,24 & 1,39 & 1,23 \\
\hline Fixed assets on revenue & 0,31 & 0,72 & 0,81 \\
\hline
\end{tabular}

Source: Author's own elaboration based on bookkeeping statement of JSC "Novoazovskoe" for 2013-2015.

Based on results of Table 19, we can see that revenue per employee is equal to 769,14 thousand rubles in 2015. 
Table 20. Profitability indicators ratios for 2013-2015, in \%.

\begin{tabular}{lrrr}
\hline \multicolumn{1}{c}{ Profitability Indicator Ratios } & $\mathbf{2 0 1 3}$ & $\mathbf{2 0 1 4}$ & $\mathbf{2 0 1 5}$ \\
\hline Return (loss) on sales & $15 \%$ & $17 \%$ & $10 \%$ \\
\hline Total return (loss) on sales & $16 \%$ & $17 \%$ & $11 \%$ \\
\hline Return (loss) on cost of revenues & $16 \%$ & $19 \%$ & $11 \%$ \\
\hline Gross profit margin & $10 \%$ & $14 \%$ & $10 \%$ \\
\hline Revenues to costs & $11 \%$ & $117 \%$ & $111 \%$ \\
\hline Economic profitability (unprofitability) & $21 \%$ & $10 \%$ & $6 \%$ \\
\hline Return (loss) on equity & $20 \%$ & $10 \%$ & $6 \%$ \\
\hline Return (loss) on capital employed & $11 \%$ & $10 \%$ & $6 \%$ \\
\hline Return (loss) on liabilities & $7077 \%$ & $4929 \%$ & $930 \%$ \\
\hline Net assets protitability (unprofitability) & $10 \%$ & $9 \%$ & $5 \%$ \\
\hline Return (loss) on assets & $20 \%$ & $10 \%$ & $6 \%$ \\
\hline Return (loss) on noncurrent assets & $48 \%$ & $22 \%$ & $12 \%$ \\
\hline Revenue on noncurrent assets & $324 \%$ & $134 \%$ & $114 \%$ \\
\hline Return (loss) on current assets & $35 \%$ & $18 \%$ & $10 \%$ \\
\hline Revenue on current assets & $237 \%$ & $106 \%$ & $100 \%$ \\
\hline EBIT on noncurrent assets & $50 \%$ & $24 \%$ & $13 \%$ \\
\hline
\end{tabular}

Source: Author's own elaboration based on bookkeeping statement of JSC “Novoazovskoe” for 2013-2015.

Based on results of Table 20, we can see that return on sales - the most important indicator - in 2015 is equal to 0,10 , what is good value for agricultural company.

Table 21. Turnover ratios for 2013-2015.

\begin{tabular}{|c|c|c|c|}
\hline Turnover ratios & 2013 & 2014 & 2015 \\
\hline Total assets turnover ratio & 1,37 & 0,59 & 0,53 \\
\hline Current assets turnover ratio & 2,37 & 1,06 & 1,00 \\
\hline Days of current assets turnover & 154 & 344 & 363 \\
\hline Noncurrent assets turnover ratio & 3,24 & 1,34 & 1,14 \\
\hline Days of noncurrent assets turnover & 113 & 272 & 320 \\
\hline Inventory turnover ratio & 3,15 & 1,32 & 1,24 \\
\hline Days of inventory turnover & 116 & 276 & 294 \\
\hline Accounts receiveable turnover & 45,23 & 22,82 & 21,87 \\
\hline Days of accounts receivable & 8 & 16 & 17 \\
\hline Accounts payable turnover & 475,45 & 269,28 & 81,14 \\
\hline Days of accounts payable & 1 & 1 & 4 \\
\hline Equity turnover ratio & 1,37 & 0,59 & 0,54 \\
\hline Days of equity turnover & 266 & 615 & 679 \\
\hline
\end{tabular}

Source: Author's own elaboration based on bookkeeping statement of JSC "Novoazovskoe" for 2013-2015.

Based on results of Table 21, we can see that in 2015 the total assets turnover ratio was equal to 0,53 which means that company generate revenue equal to total cost of assets at 180 days.

\subsection{CVP-analysis of JSC "Novoazovskoe"}

Cost-Volume-Profit (CVP) analysis is based upon determining the breakeven point of cost and volume of goods and can be useful for managers making short-term economic decisions. Costvolume profit analysis makes several assumptions in order to be relevant including that the sales price, fixed costs and variable cost per unit are constant. Running this analysis involves using several equations using price, cost and other variables and plotting them out on an economic graph (Horngren, Harrison, \& Oliver, 2012). 
Breakeven point determines the volume of sales for covering of all expenditures and generates profit. For calculation of breakeven point used data from bookkeeping statements and Form 9 and 13 of JSC "Novoazovskoe". Because of the inability of common calculation of the breakeven points for the crop and livestock production, data for the calculations are presented in two Tables separately for grain and milk. Results are presented in the following tables.

Table 22. Results of grain production in JSC "Novoazovskoe" for 2013-2015.

\begin{tabular}{|c|c|c|c|c|c|c|c|c|c|}
\hline \multirow{2}{*}{ Parameter } & \multicolumn{3}{|c|}{ Year } & \multicolumn{2}{|c|}{2014 to 2013} & \multicolumn{2}{|c|}{2015 to 2014} & \multicolumn{2}{|c|}{2015 to 2013} \\
\hline & 2013 & 2014 & 2015 & Amount & In \% & Amount & $\ln \%$ & Amount & $\ln \%$ \\
\hline Production sold, centner & 47945 & 87103 & 52901 & 39158 & $181,7 \%$ & -34202 & $60,7 \%$ & 4956 & $110,3 \%$ \\
\hline Revenues, thousand rubles & 22333 & 48765 & 36365 & 26432 & $218,4 \%$ & -12400 & $74,6 \%$ & 14032 & $162,8 \%$ \\
\hline per centner of grain & 0,47 & 0,56 & 0,69 & 0,09 & $120,2 \%$ & 0,13 & $122,8 \%$ & 0,22 & $147,6 \%$ \\
\hline Cost, thousand rubles & 22118 & 46059 & 36528 & 23941 & $208,2 \%$ & -9531 & $79,3 \%$ & 14410 & $165,2 \%$ \\
\hline per centner of grain & 0,46 & 0,53 & 0,69 & 0,07 & $114,6 \%$ & 0,16 & $130,6 \%$ & 0,23 & $149,7 \%$ \\
\hline Fixed cost, \% & 0,70 & 0,70 & 0,67 & $x$ & $x$ & $x$ & $x$ & $x$ & $x$ \\
\hline Variable cost, \% & 0,30 & 0,30 & 0,33 & $\mathrm{x}$ & $\mathrm{x}$ & $x$ & $x$ & $x$ & $x$ \\
\hline Fixed cost, thousand rubles & 15483 & 32241 & 24474 & 16759 & $208,2 \%$ & -7768 & $75,9 \%$ & 8991 & $158,1 \%$ \\
\hline per centner of grain & 0,32 & 0,37 & 0,46 & 0,05 & $114,6 \%$ & 0,09 & $125,0 \%$ & 0,14 & $143,3 \%$ \\
\hline Variable cost, thousand rubles & 6635 & 13818 & 12054 & 7182 & $208,2 \%$ & -1763 & $87,2 \%$ & 5419 & $181,7 \%$ \\
\hline per centner of grain & 0,14 & 0,16 & 0,23 & 0,02 & $114,6 \%$ & 0,07 & $143,6 \%$ & 0,09 & $164,6 \%$ \\
\hline Profit, thousand rubles & 215 & 2706 & -163 & 2491 & $1258,6 \%$ & -2869 & $-6,0 \%$ & -378 & $-75,8 \%$ \\
\hline per centner of grain & 0,00 & 0,03 & 0,00 & 0,03 & $692,8 \%$ & $-0,03$ & $-9,9 \%$ & $-0,01$ & $-68,7 \%$ \\
\hline
\end{tabular}

Source: Author's own elaboration based on bookkeeping statement of JSC "Novoazovskoe" for 2013-2015.

Based on the Table 22, the volume of crop production (grain) temporary was gained in 2014 on $39,16 \mathrm{mln}$ rubles $(181,7 \%)$, but in 2015 was decreased on $34,2 \mathrm{mln}$ rubles $(39,3 \%)$ in relation to 2014.

Breakeven point in monetary terms is calculating according to the formula:

$$
B P=R^{*} F C /(R-V C)
$$

where, $\mathrm{R}$ - revenues from sales; VC - variable cost; FC - fixed cost; BP - breakeven point in money.

By using of data from Table 22 and formula (1) can be calculated minimal quantity of production and minimal amount of revenues. Results are in the Table 23. 
Table 23. Results of breakeven point in crop production in JSC "Novoazovskoe" for 2013-2015.

\begin{tabular}{cccccccccc}
\hline Parameter & & Year & & \multicolumn{2}{c}{$\mathbf{2 0 1 4}$ to 2013 } & 2015 to 2014 & 2015 to 2013 \\
\hline Type of breakeven point & 2013 & 2014 & 2015 & Amount & In \% & Amount & In \% & Amount & In \% \\
\hline Breakeven point, in amount & 22027 & 44989 & 36609 & 22962 & $204,2 \%$ & -8380 & $81,4 \%$ & 14582 & $166,2 \%$ \\
\hline Breakeven point, in weight & 47288 & 80359 & 53256 & 33070 & $169,9 \%$ & -27103 & $66,3 \%$ & 5967 & $112,6 \%$ \\
\hline
\end{tabular}

Source: Author's own elaboration based on bookkeeping statement of JSC "Novoazovskoe" for 2013-2015.

More graphically it's presented on the Figures 12 and 13.

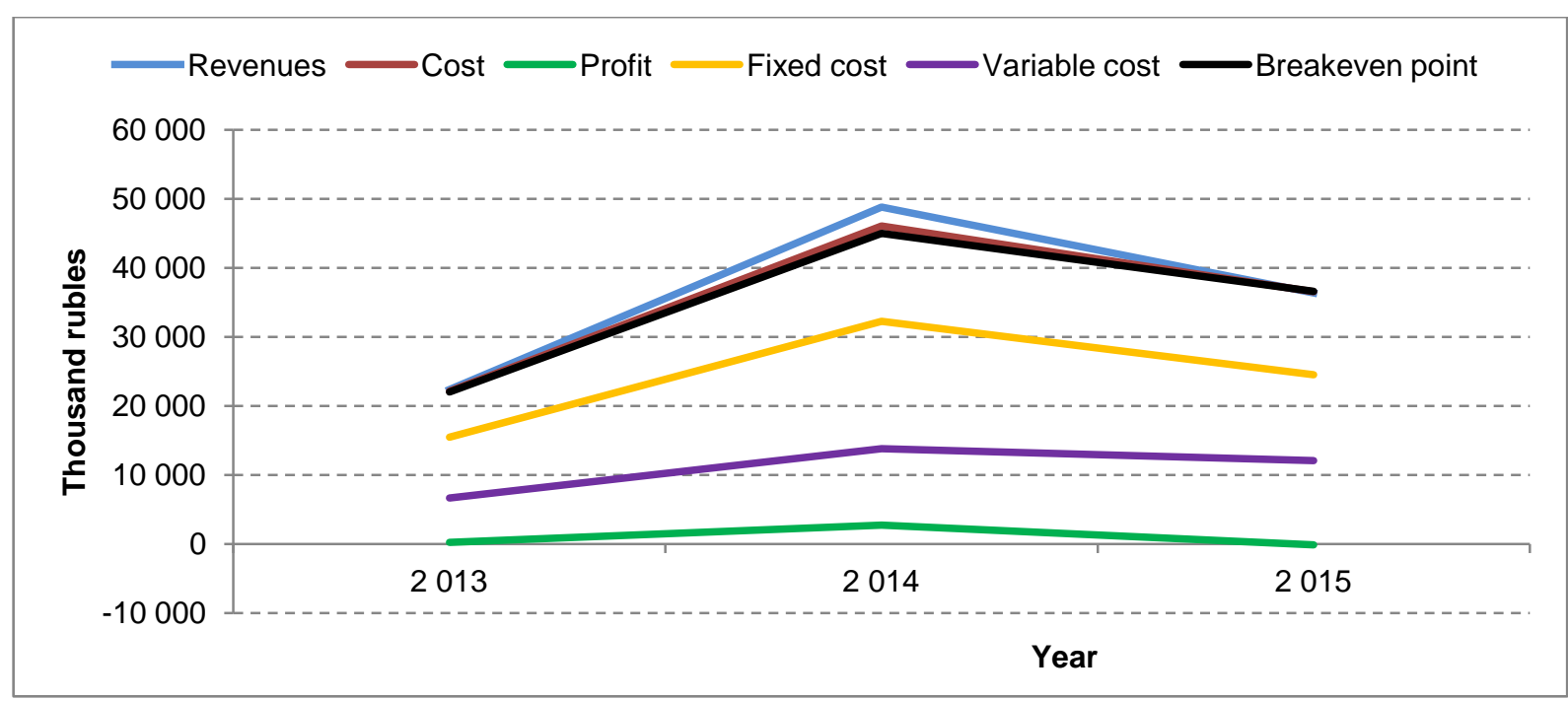

Figure 12. Financial results and breakeven point of crop production, in thousands rubles.

Source: Author's own elaboration based on bookkeeping statement of JSC "Novoazovskoe" for 2013-2015.

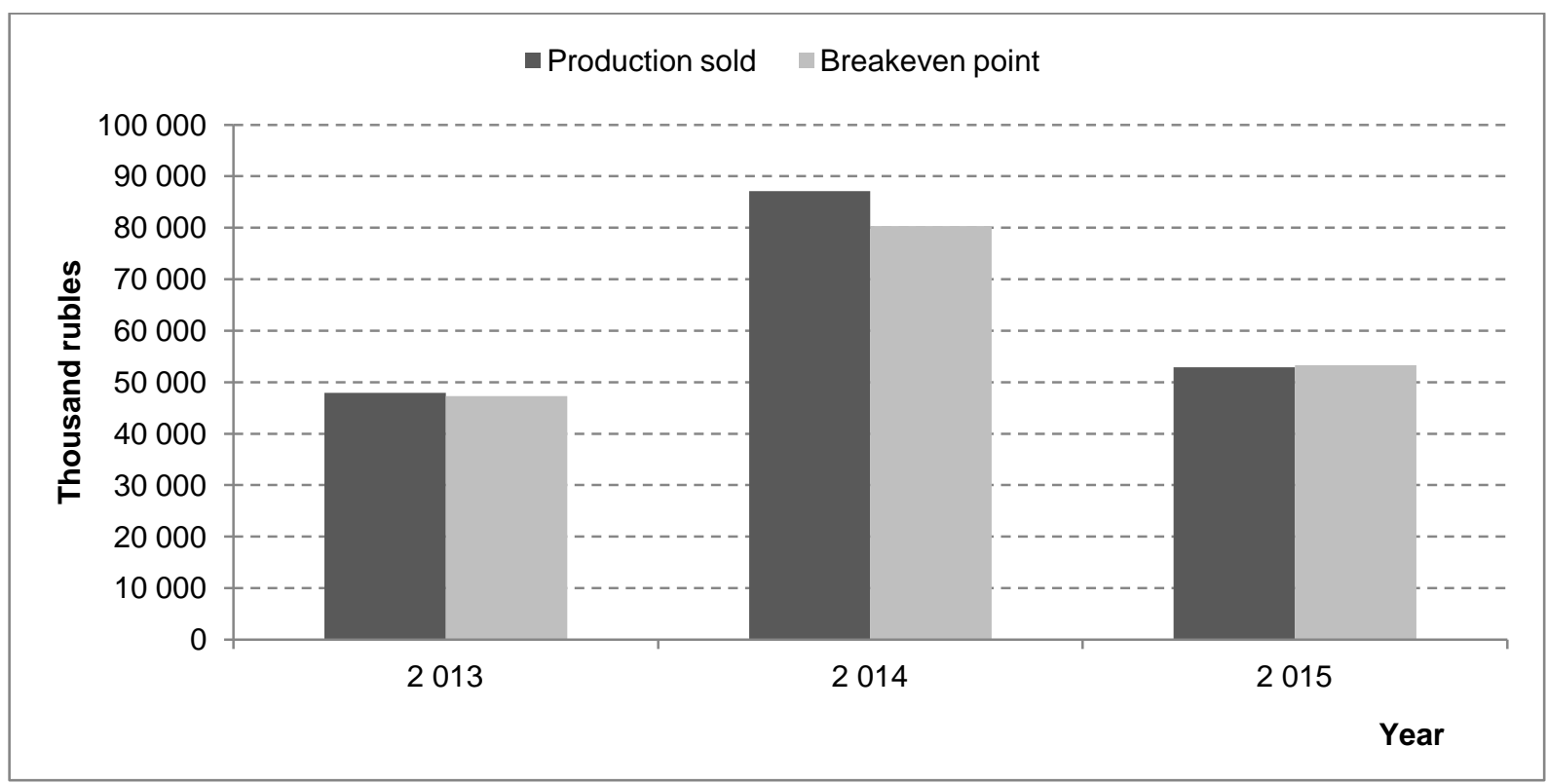

Figure 13. Production results and breakeven point of crop production, in centners.

Source: Author's own elaboration based on bookkeeping statement of JSC "Novoazovskoe" for 2013-2015. 
As we can see from the graphs and tables, the breakeven point in monetary terms in 2015 is bigger, then current revenues and total costs, and also bigger than profit, variable and fixed costs. This situation means that to cover all of the cost obtained from the crop production need to generate more revenues, than it is generating in 2015. Also in production terms in 2015 the breakeven point is higher than current scope of production. That also means that to get the revenues needed to cover all of the cost need to product the indicated amount of production. Also, we can consider on the graphs, that activity has the negative trend. Based on that, we can consider that in monetary and production terms crop production on the year 2015 is not profitable for JSC "Novoazovskoe", but has the opportunity to grow.

In same way is proceeding the CVP and breakeven point analyses of milk production. Data are presented in the Table 24.

Table 24. Results of milk production in JSC "Novoazovskoe" for 2013-2015.

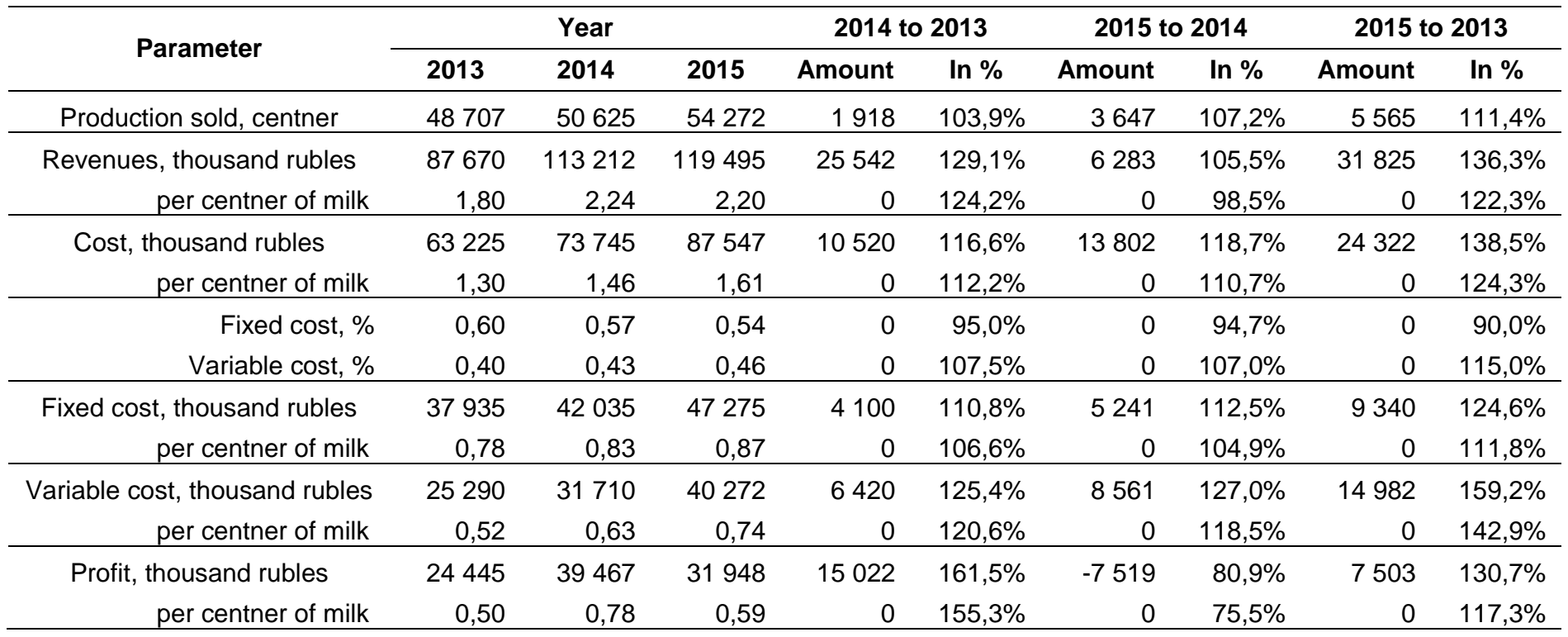

Source: Author's own elaboration based on bookkeeping statement of JSC "Novoazovskoe" for 2013-2015.

Based on data from Table 24, we see that volume of sold milk production increased on 5565 centners $(111,4 \%)$, and in monetary term on 31825 thousand rubles $(136,3 \%)$. Profit from sold milk production increased on 7503 thousand rubles $(130,7 \%)$.

By using of data from Table 23 and formula (1) can be calculated minimal quantity of production and minimal amount of revenues. Results are in the Table 25.

Table 25. Results of breakeven point in milk production in JSC "Novoazovskoe" for 2013-2015.

\begin{tabular}{|c|c|c|c|c|c|c|c|c|c|}
\hline \multirow{2}{*}{ Type of breakeven } & \multirow{2}{*}{2013} & \multirow{2}{*}{2014} & \multirow{2}{*}{2015} & \multicolumn{2}{|c|}{2014 to 2013} & \multicolumn{2}{|c|}{2015 to 2014} & \multicolumn{2}{|c|}{2015 to 2013} \\
\hline & & & & Amount & $\ln \%$ & Amount & $\ln \%$ & Amount & $\ln \%$ \\
\hline Breakeven point, in amount & 53315 & 58389 & 71307 & 5075 & $109,5 \%$ & 12918 & $122,1 \%$ & 17992 & $133,7 \%$ \\
\hline Breakeven point, in weight & 29620 & 26110 & 32386 & -3510 & $88,1 \%$ & 6276 & $124,0 \%$ & 2766 & $109,3 \%$ \\
\hline
\end{tabular}

Source: Author's own elaboration based on bookkeeping statement of JSC "Novoazovskoe" for 2013-2015. 
More graphically it's presented on the Figures 14 and 15.

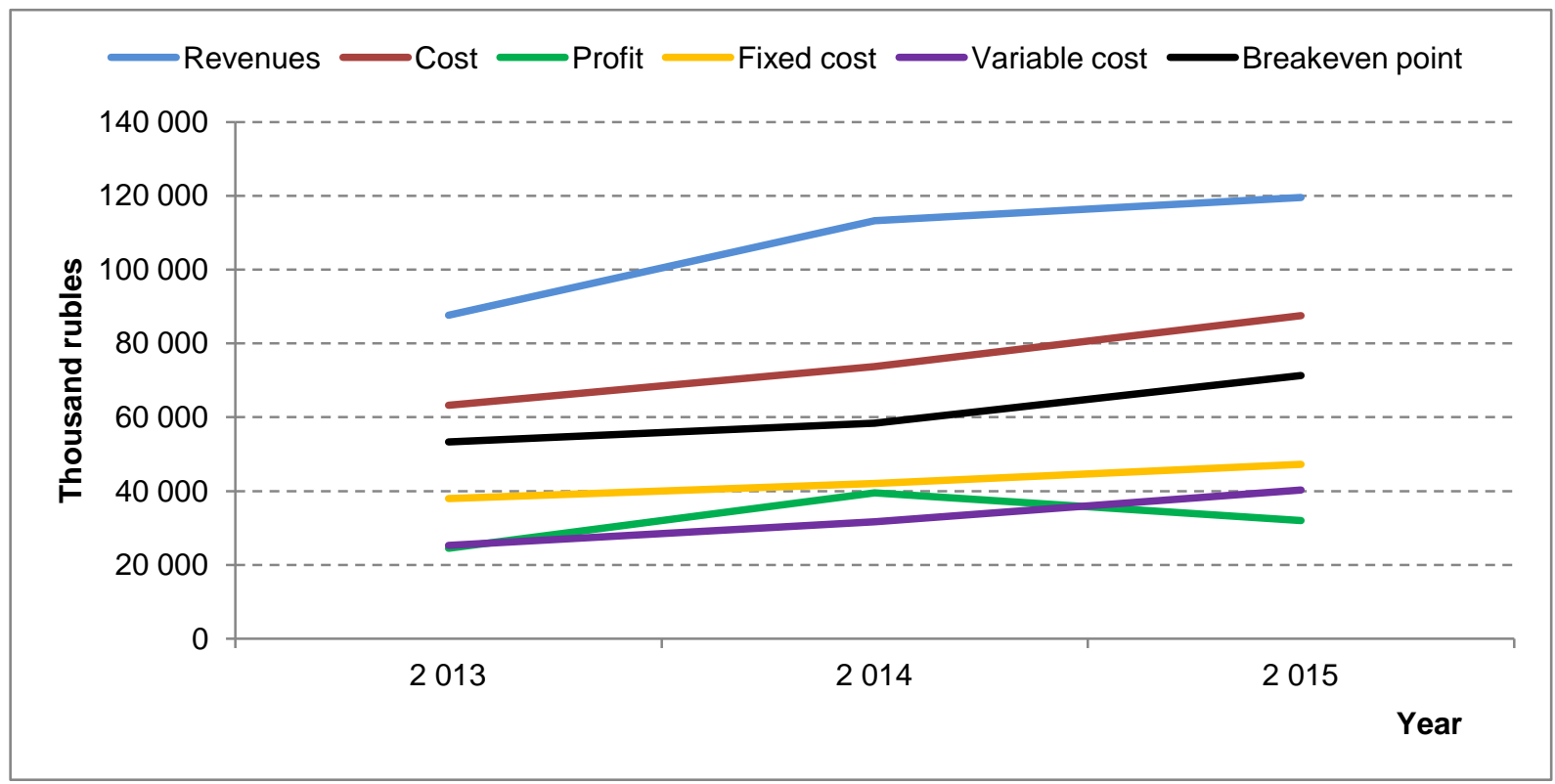

Figure 14. Financial results and breakeven point of milk production, in thousands rubles.

Source: Author's own elaboration based on bookkeeping statement of JSC "Novoazovskoe" for 2013-2015.

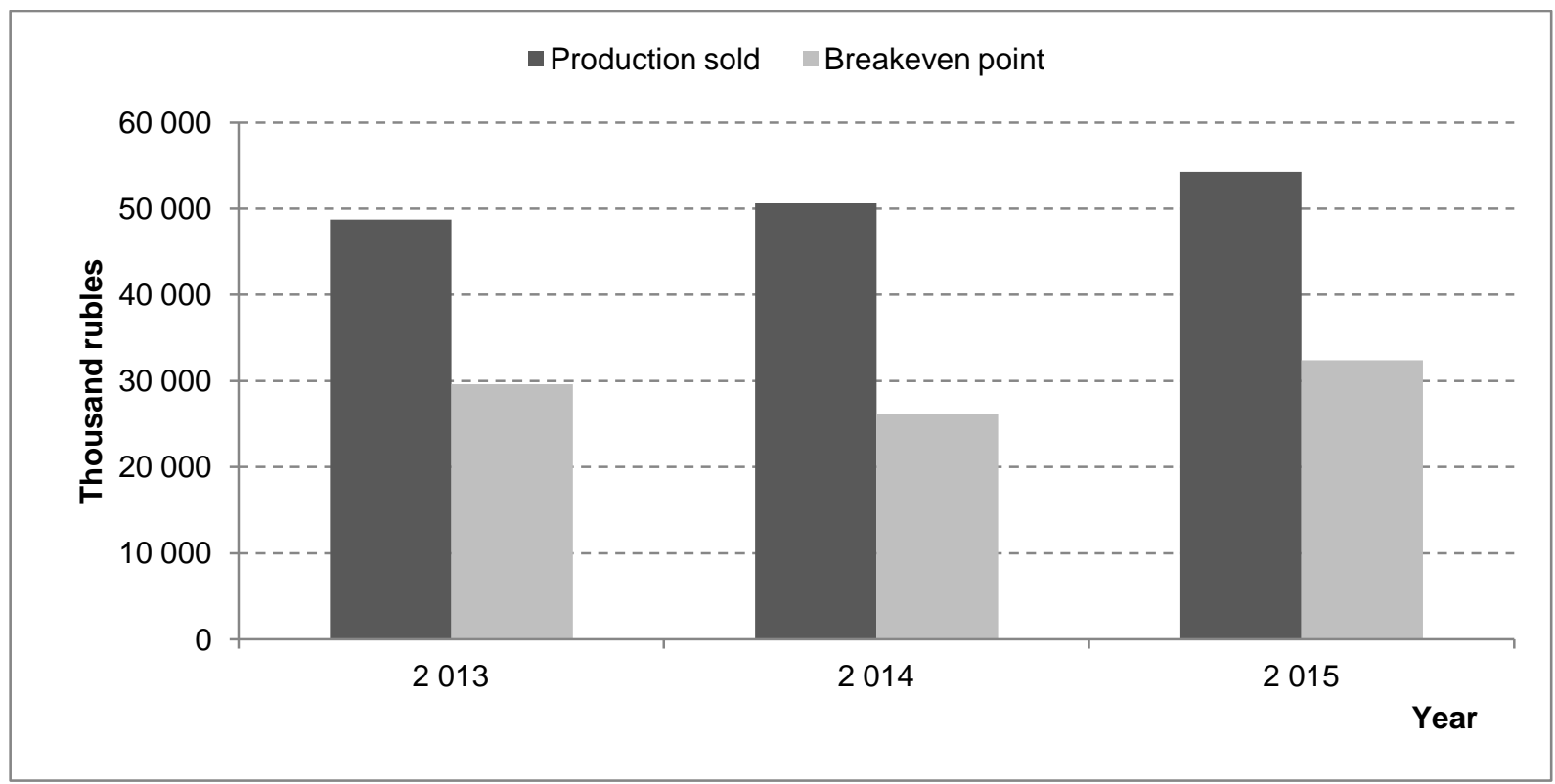

Figure 15. Production results and breakeven point of milk production, in centners.

Source: Author's own elaboration based on bookkeeping statement of JSC "Novoazovskoe" for 2013-2015.

As we can see from the graphs and tables, the breakeven point in monetary terms is much smaller, then current revenues and total costs, but bigger than profit, variable and fixed costs. As well as in Iproduction terms breakeven point is lower than current scope of production. Based on that, we can consider that in monetary and production terms milk production is profitable for JSC "Novoazovskoe". 


\section{Financial strength indicator}

For how far an enterprise from the breakeven point shows the financial strength indicator. This value shows for how much percent production can be decreased without loses. Financial strength indicator is calculating according to the formula:

$$
F S I=(R-B P) / R * 100 \%,
$$

where, $\mathrm{R}$ - Revenues; BP - Breakeven point in monetary terms.

This indicator needs to be calculated for each specified product. Data obtained from Tables 22-25, and results are in the Table 26.

Table 26. Financial strength indicator for crop and milk production in JSC "Novoazovskoe" for 2013-2015, in \%.

\begin{tabular}{lrrc}
\hline \multicolumn{1}{c}{ Kinds of production } & 2013 & \multicolumn{1}{c}{2014} & \multicolumn{1}{c}{2015} \\
\hline Crop production & 1,37 & 7,74 & $-0,67$ \\
\hline Milk production & 39,19 & 48,42 & 40,33 \\
\hline
\end{tabular}

Source: Author's own elaboration based on bookkeeping statement of JSC "Novoazovskoe" for 2013-2015.

After calculation, we can see that, during all considering years, crop production was not in the safety area - was less than $10 \%$. Also, in 2015 crop production got the loss, therefore the financial strength indicator showed the negative result of $0,67 \%$. This issue means that crop production was not in financial safety area. On the other hand, milk production increased position in safety area from $39,19 \%$ to $40,33 \%$ in 2013 and 2015 accordingly, with the temporal growth of indicator to $48,42 \%$. That means that milk productions in JSC "Novoazovskoe" is in safety area and generate profit from activity.

To complete the analysis and to evaluate the competitive advantages of JSC "Novoazovskoe" it was performed the SWOT Analysis.

SWOT analysis (alternatively SWOT matrix) is an acronym for strengths, weaknesses, opportunities, and threats and is a structured planning method that evaluates those four elements of an organization, project or business venture. A SWOT analysis can be carried out for a company, product, place, industry, or person. It involves specifying the objective of the business venture or project and identifying the internal and external factors that are favorable and unfavorable to achieve that objective (Osita, Onyebuchi, \& Nzekwe, 2017). Results of implementation of this analysis are in the Table 27

Table 27. SWOT Analysis of JSC "Novoazovskoe".

\section{STRENGTHS}

- $\quad$ Big production and managerial experience;

- Balanced system of milk production and feed harvesting;

- Presence of permanent and reliable suppliers of equipment and materials, as well as permanent buyers;

- Relatively close to the city of Omsk - less $15 \mathrm{~km}$ - the major center of production distribution.

\section{WEAKNESS}

- $\quad$ Low quality of harvested feeds because of big loss of harvested feeds as the result of improper and old-style process of harvesting and storage of them;

- Unacceptable conditions of storage of haylage, and its loss of more than half of nutrition value;

- Lack of modern equipment for feed harvesting, storage and delivery. 


\begin{tabular}{|c|c|}
\hline $\begin{array}{l}\text { OPPORTUNITIES } \\
\text { - Ability to serve additional groups of consumers - } \\
\text { farmers of Ural, Far East of Russia, as well as } \\
\text { the countries of near abroad countries: } \\
\text { Kazakhstan, Uzbekistan, Tadzhikistan, } \\
\text { Kyrgyzstan, Mongolia and China; } \\
\text { Opportunity to enter to other markets of feeds, for } \\
\text { example: haylage and silage. }\end{array}$ & $\begin{array}{l}\text { THREATS } \\
\text { - Change of climate and weather conditions, crop } \\
\text { failure, low milk yield, loss of cattle; } \\
\text { - Strengthening of positions of local competitors } \\
\text { with equal costs or enter the foreign producers } \\
\text { with super-modern technologies, leading to } \\
\text { decreasing of cost of production and increasing } \\
\text { of high quality; } \\
\text { - The lack of sufficient support and crop insurance } \\
\text { from the state; } \\
\text { - Decline of purchasing prices by dealers; } \\
\text { - } \quad \text { Ancrease of energy prices, fertilizers, feeds; }\end{array}$ \\
\hline
\end{tabular}

Source: Author's own elaboration.

The main threats are associated with the production of the main product - milk. A weakness is in the low quality of harvested haylage, as well as the absence of certain types of agricultural machinery, necessary for a complete modern harvesting, transportation and storage of feed. In spite of balanced and proven technology of harvesting and feeding, the company remains competitive mainly due to the passive presence of foreign competitors in the market. But the management's policy is directed on creation of hi-tech and modern production, new markets and new products, constant updating of agricultural machinery, use of new varieties of crops and the use of science-based technologies of their cultivation, are factors which, in consequence, able to make the company as a strong competitor even for foreign manufacturers. 


\section{Increasing the economic sustainability of JSC "Novoazovskoe"}

\subsection{Description of existing harvesting system and identifying the reasons for managerial decisions in JSC "Novoazovskoe"}

The SWOT Analysis implemented in the second chapter of this Master thesis helped to detect the weakness of JSC "Novoazovskoe", among which are:

- Low quality of harvested feeds because of big loss of harvested feeds as the result of improper and old-style process of harvesting and storage of them;

- Unacceptable conditions of storage of haylage, and its loss of more than half of nutrition value;

- Lack of modern equipment for feed harvesting, storage and delivery.

As the result of research of organizational and economic state of an enterprise, calculation of innovative activity indicators, as well as state of plant growing and livestock production branches, together with specialists and top-management of the company, were discussed the possible direction of development. By the priority trends were chosen: increasing of quality of harvesting feeds. We will consider some the propositions.

For harvesting and storage of feeds it is necessary to do:

- improve of the quality of harvested haylage by equal distribution and drying of all harvested mass on the field to $50-55 \%$ of moisture;

- purchase of a baler, helping to solve the problem with saving the quality of feeds during all term of its storage;

- foreign substances exclusion in haylage, preventing of forming of pathogenic microorganisms negatively impacting on the health of animals (Agrovesti.net, 2016).

We consider all of the mentioned above measures more in details. Negative results of use of existing type of harvesting process are schematically presented on the Figure 16. 


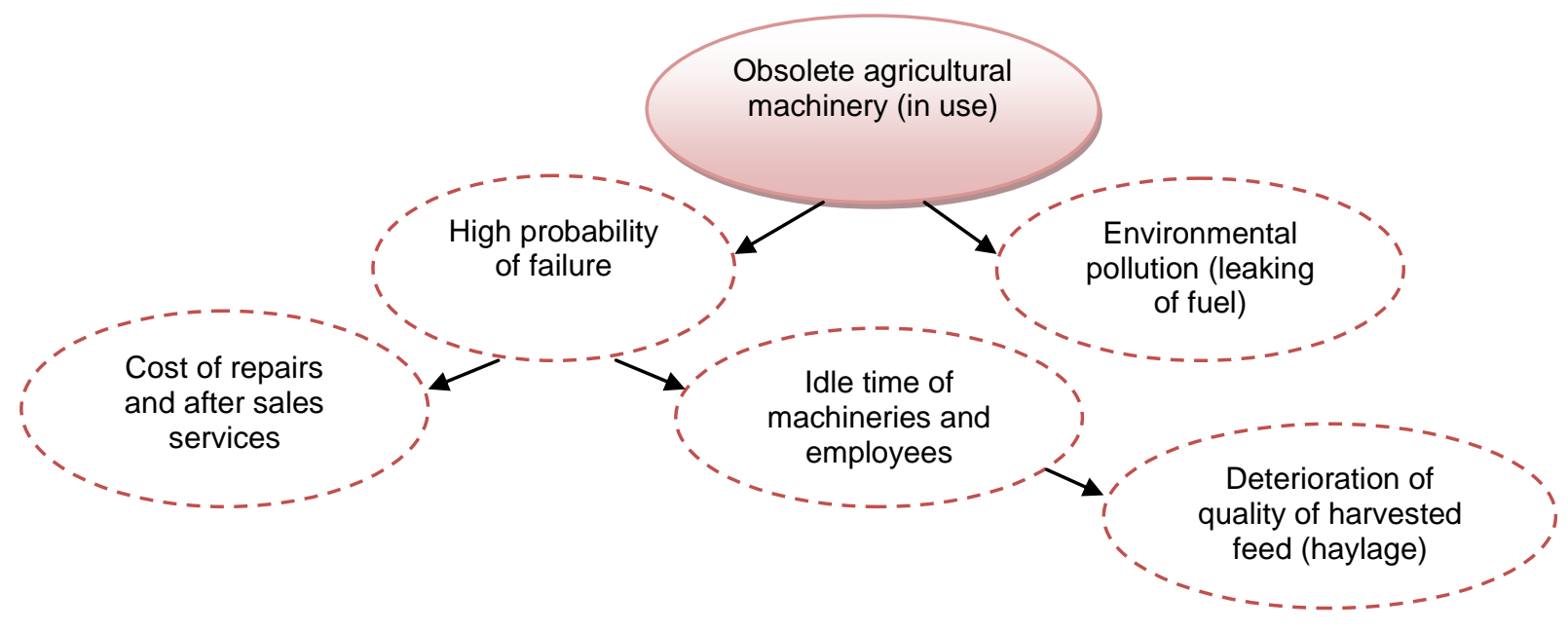

Figure 16. Negative results of obsolete machineries use in haylage harvesting process.

Source: Author's own elaboration.

In monetary terms, the cost of repairs and idle time of machineries and employees during haylage harvesting process are presented in the Table 28. Data are obtained from managerial statement of JSC "Novoazovskoe".

Table 28. Cost of repairs and idle time during haylage harvesting process.

\begin{tabular}{|c|c|c|c|}
\hline Indicator & 2013 & 2014 & 2015 \\
\hline \multicolumn{4}{|l|}{ Machinery idle time, hours } \\
\hline Tractor MTZ-82 & 8 & 15 & 10 \\
\hline Mower & 0 & 15 & 8 \\
\hline \multicolumn{4}{|l|}{ Salary, rubles/hour } \\
\hline Tractor-driver & 96 & 118 & 129 \\
\hline Mower operator & 96 & 118 & 129 \\
\hline \multicolumn{4}{|l|}{ Salary in idle time, rubles } \\
\hline Tractor-driver & 771 & 1763 & 1292 \\
\hline Mower operator & 0 & 1763 & 1034 \\
\hline \multicolumn{4}{|l|}{ Cost of repairs, rubles } \\
\hline Tractor MTZ-82 & 24500 & 0 & 6100 \\
\hline Mower & 0 & 42300 & 13800 \\
\hline \multicolumn{4}{|l|}{ TOTAL, rubles } \\
\hline Tractor MTZ-82 & 25271 & 1763 & 7392 \\
\hline Mower & 0 & 44063 & 14834 \\
\hline TOTAL for harvest, rubles & 25271 & 45826 & 22226 \\
\hline Accumulated result & 25271 & 71096 & 93322 \\
\hline
\end{tabular}

Source: Author's own elaboration based on bookkeeping statement and managerial statement of JSC "Novoazovskoe".

As we can see from the Table 28, accumulated result of repairs of machineries and idle time of machineries and employees has cost to the company 93322 rubles. It is not the crucial expenditures, but company should spend money on it, interrupt the harvesting process, and as a result obtain improperly harvested haylage.

At the present time in JSC "Novoazovskoe" is using the following scheme of haylage harvesting: 
1. Mowing of perennial grasses (alfalfa) for haylage by the self-propelled mower Mac Don (operating width $-6 \mathrm{~m}$ ). Making of the rolls for drying of the cut mass;

2. Collection of the dried rolls by the rack-rollmakers Dominator Tonutti (operating width -6 $\mathrm{m})$ in one roll;

3. Picking up and grinding of cut mass by the UEM-280 with loading of gridded mass in the truck aggregated to the tractor MTZ-82;

4. Transportation of the haylage in the truck to the specially equipped haylage pit;

5. Unloading of haylage into haylage pit, compaction by the tractor MTZ-82;

6. Close of haylage pit by the water and airtight film.

Advantages of haylage harvesting system is its simplicity. Among the disadvantages could be selected the following:

1) When rolls are making for drying, the whole mass is drying unevenly, and as the result there is the loss of nutrition of haylage. The scheme of roll's nutrition is presented on the Figure 17:

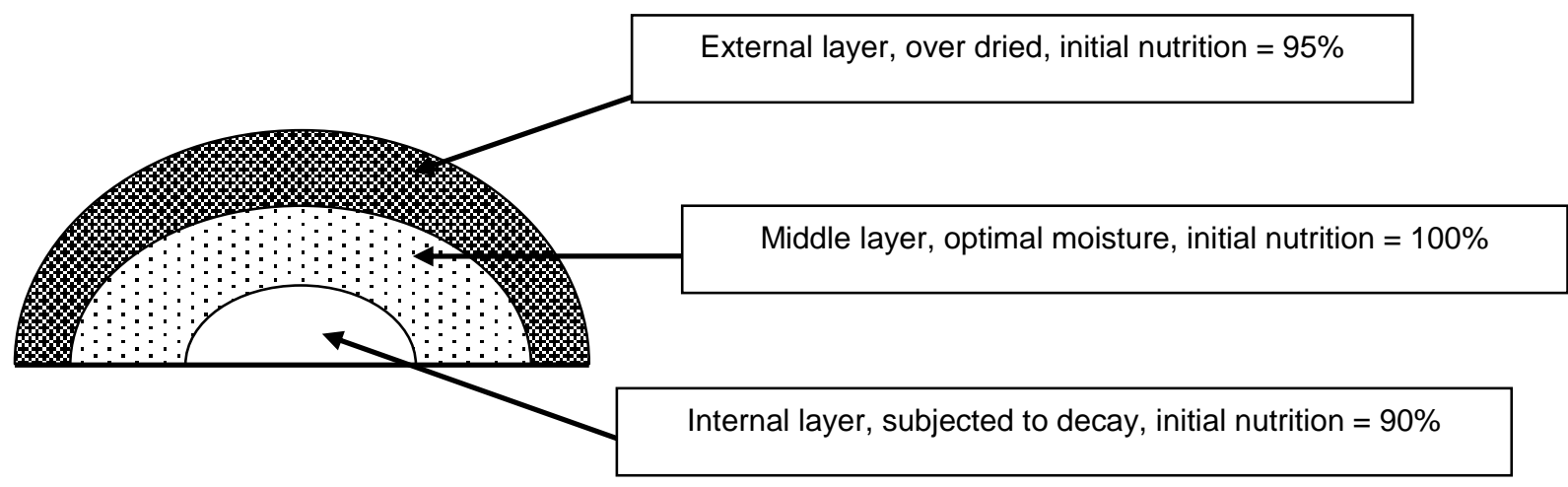

Figure 17. Structure of haylage roll, longitudinal section.

Source: Author's own elaboration.

As we can see from the picture 17 , the total nutrition of haylage in the result is $85 \%$ in average from initial.

2) During transportation of haylage in a truck in the haylage mass can penetrate various harmful substances, microorganisms and inimical bacteria, which can negatively affect on the health of animals and their productivity;

3) During compressing of haylage by the tractor, into the haylage can penetrate the gasoline and oil, dirt, various harmful substances, which also affect on the future quality of the feeds and animals health;

4) During covering of haylage by protective film can be possible damages of film itself and penetration of pathogenic microbes and harmful substances, as well as water penetration during winter, which negatively affect on the quality of haylage. Also, covering of the haylage pit by the film doesn't make the sealed conditions for storage, what leads to the damage of feeds; 
5) When haylage is used during the winter and spring, goes the unsealing of a haylage pit, and in haylage penetrate the air and water, what leads to decay of feed;

6) Entire harvesting process takes around 5 days.

\subsection{Rationale of managerial decision and description of proposed harvesting system}

Schematically, the reasons and results of reduction of haylage quantity and quality are presented on the Figure 18.

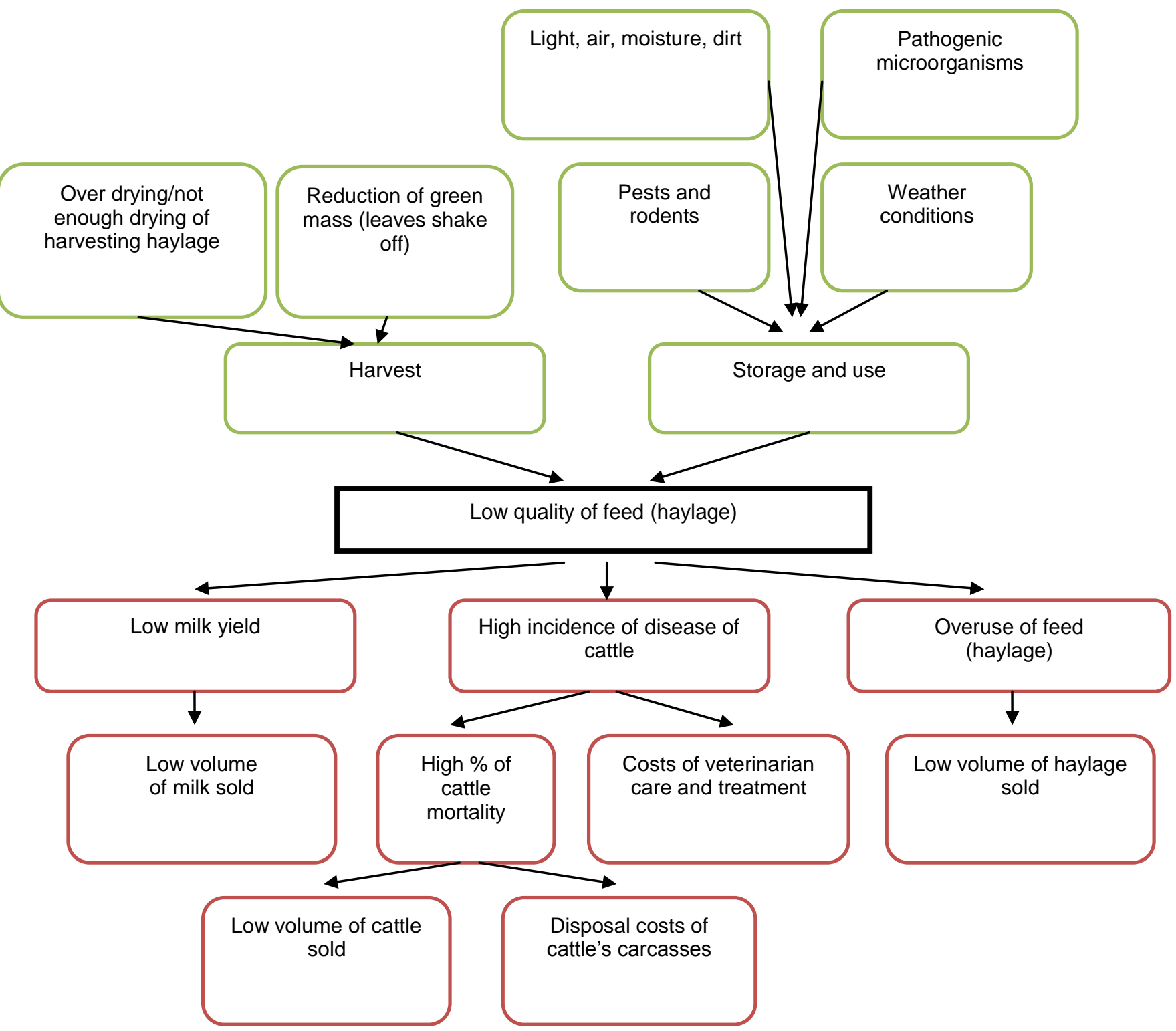

Figure 18. Scheme of reasons and results of quality and quantity decline of harvesting haylage.

Source: Author's own elaboration. 
As we can see from the Figure 18, low quality of harvesting haylage leads to the mix of problem, which, finally, leads to the economic instability of a company. More in details the loss of quality and quantity is presented on the Figure 19.

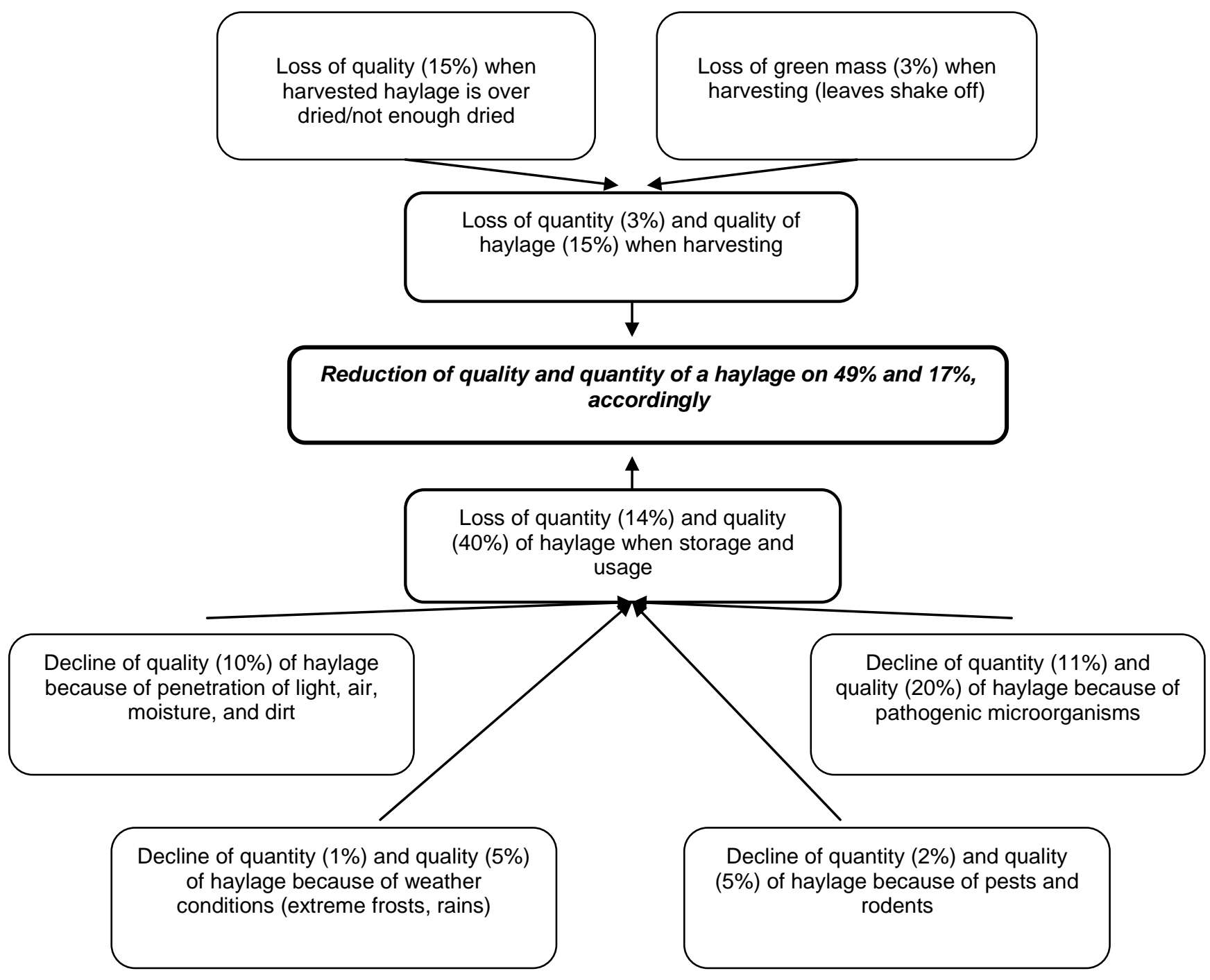

Figure 19. Reasons of reduction of quality and quantity of a haylage, in $\%$.

Source: Author's own elaboration.

As the result of mentioned above negative factors, the haylage loses its nutrition, what can lead to decline of amount of revenues from haylage realization because of the low quality, and to decline of productivity of cows because of bad quality feed (LBR Agromarket, 2017; Labocky, 2013; Krestiansky dom, 2015). More in details it will be described in the chapter 4.3 of this Master thesis. For minimization of negative impact of these factors on the quality of harvested haylage, and as the result, on health of animals and theirs productivity, we propose to review the harvesting system, implement new agricultural machinery according to the requirement of modern harvesting process. This process includes the following initial expenditures: 
— purchasing of rotary tedder;

— purchasing of chamber baler;

— purchasing of bale wrapper;

— purchasing of front loader with bales grabber.

Required funds for purchasing of agricultural machineries will be invested from the net profit of JSC "Novoazovskoe", received in 2015. For easier understanding of information, it is necessary to give the explanation of implemented kinds of machinery:

1) Rotary tedder - designed for intensive and thorough tedding of cut mass of roll and swaths. Regular tedding of cut mass - is the required operation for good-quality feed harvesting, one of the option of active ventilation on a field. During tedding of fresh or weakly wilted grass, leaves stay on the stems. No loss of grass weight.

2) Chamber baler - designed for picking up and compression the mass of grass into the bales irrespective of its moisture (haylage, hay, straw, flax), with binding of bales by the plastic grid or twine. Forms the bales of proper cylindrical form, ensure the thorough pick up and high density of grass mass.

3) Bale wrapper - designed for packing of grass mass in bales into the special film (agrostretch) for maximum saving of nutrition of feeds without use of preservatives.

4) Front loader - designed for lifting, uploading, movement, piling of baled feeds and other agricultural cargo.

Advantages of proposed harvesting system are presented in the Figure 20.

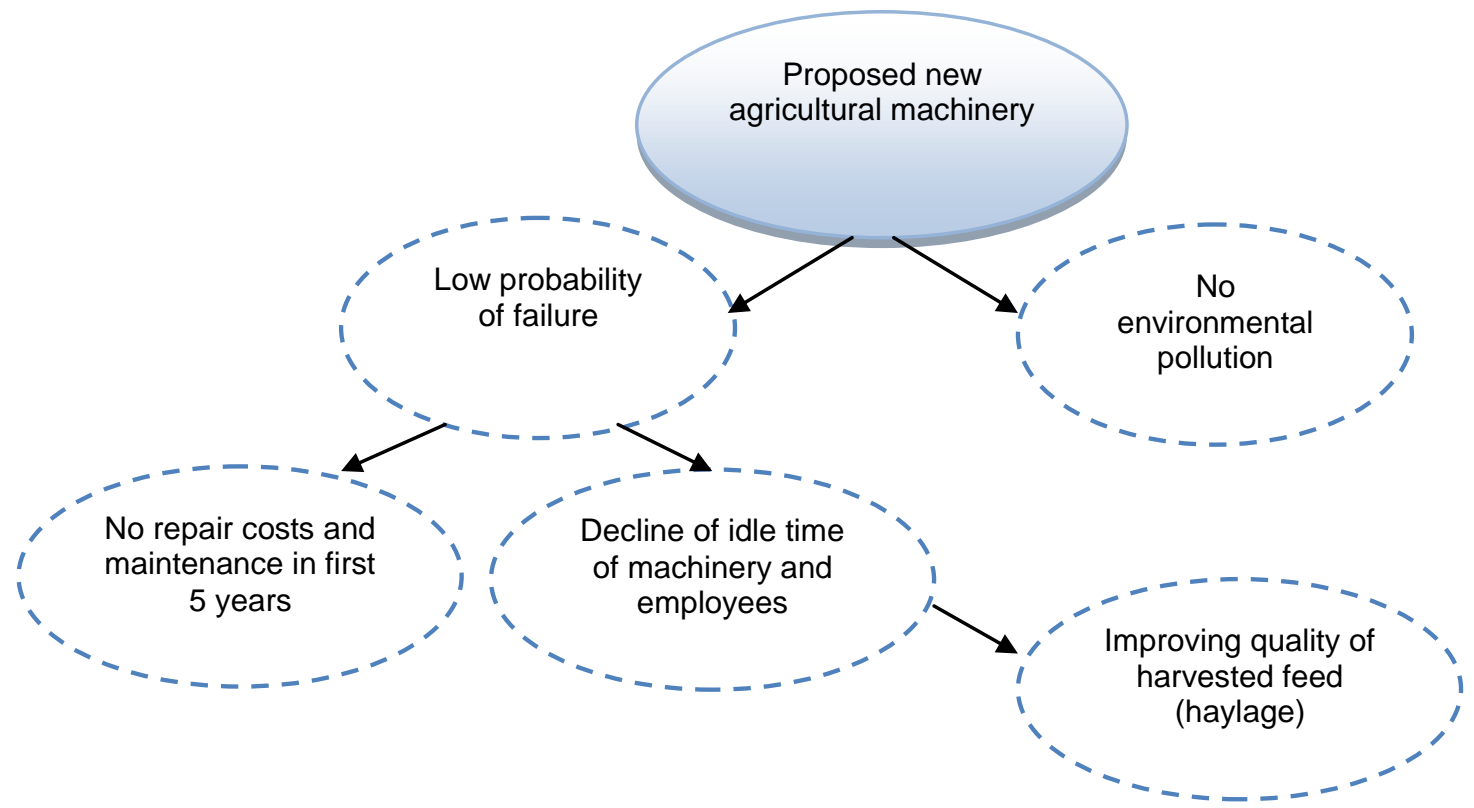

Figure 20. Effect after implementation of new agriculture machineries for haylage harvesting process.

Source: Author's own elaboration. 
As we can see from the Figure 20, expenditures for repairs and maintenance will be minimized or completely eliminated.

After implementation of new agricultural technology, the process of harvesting will be look like the following:

1. Mowing of perennial grasses (alfalfa) for haylage by the self-propelled mower Mac Don (operating width $-6 \mathrm{~m}$ ). Making the rolls for drying of cut mass;

2. Tedder and distribution of rolls on the field for equal drying by the rotary tedder;

3. Assembly of the rolls by the rack-rollmakers Dominator Tonutti (operating width $-6 \mathrm{~m}$ ) in one big roll;

4. Picking up, compression, forming in the cylindrical form, and wrapping of bales by the grid with chamber baler aggregated with the tractor MTZ-82, unloading of wrapped bales on the field;

5. Picking up and wrapping of bales by the moisture and airtight film agrostretch by the bale wrapper aggregated with the tractor MTZ-82, unloading of packed bales on the field;

6. Picking up of packed bales by the front loader with bales grabber aggregated with the tractor MTZ-82 and uploading of them into the tractor's truck aggregated with the tractor MTZ-82;

7. Delivery of packed bales to the store and unloading with the front loader with bales grabber aggregated with the tractor MTZ-82;

8. Storage of packed bales of haylage, use when the need arises.

Advantages of this type of harvesting is the following:

- Decline of harvesting period from 5 to 2 days;

- Absence of necessity to make the special waterproof haylage pit;

- Total sealing of production, protection from penetration of air, moisture, harmful substances and microorganisms, direct sunlight;

- Keeping of haylage with moisture of $50-55 \%$ in which growth of microorganisms in haylage is impossible;

- Convenience during transportation and storage of production.

Also, the reason of selection of these harvesting and storage processes of feed is an increased keeping of nutrition in relation to tranche technology, (Malinin, 2013; Ukrprolife, 2012; Zootehnikoff.ru, 2014). Data are presented in the Table 29. 
Table 29. Quality of different kinds of harvested feeds.

\begin{tabular}{lrr}
\hline \multicolumn{1}{c}{ Parameters (content in dry matter) } & Packed haylage & Tranche technology \\
\hline Dry matter, \% & 48,14 & 45,0 \\
\hline Crude fat, \% & 2,91 & 4,07 \\
\hline Crude protein, \% & 19,66 & 20,81 \\
\hline Crude fiber, \% & 25,7 & 30,16 \\
\hline Sugar, \% & 5,94 & 5,0 \\
\hline Crude carotene, mg/kg & 54,07 & 58,0 \\
\hline pH & 4,71 & 5,3 \\
\hline Content of acetous acid, \% & 0,55 & 11 \\
\hline Butyric acid, \% & 0,01 & 6,7 \\
\hline Milk acid, \% & 3,08 & 0,38 \\
\hline Content of energy, MJ/kg & 10,81 & 4,2 \\
\hline
\end{tabular}

Source: Agrovestnik.ru (2016); Zootehnikoff.ru (2014).

As we can see from the table, parameters of packed haylage are exceeding the analogical parameters of haylage in tranches, what is suggesting about much higher level of preservation of the feed and its nutrition.

For further estimation of investments' effectiveness it is required to consider each new stage of the process of harvesting, as well as to compare purchased analogues.

\section{Teddering}

First implementing stage - teddering of rolls and spreading of it on the field for gaining of $50-55 \%$ level of moisture and equal drying. Operating principle of rotary tedder is simple: directly after the self-propelled mower Mac Don on the field enters the rotary tedder aggregated with MTZ-82, which spreading 2 rolls on 5.5 meters. As the result - the haylage is distributing on the field in equal layer. After 2-4 hours (according to the weather conditions) the haylage is gaining required moisture. Difference between implemented scheme of drying and existing one is presented on the Figure 21.

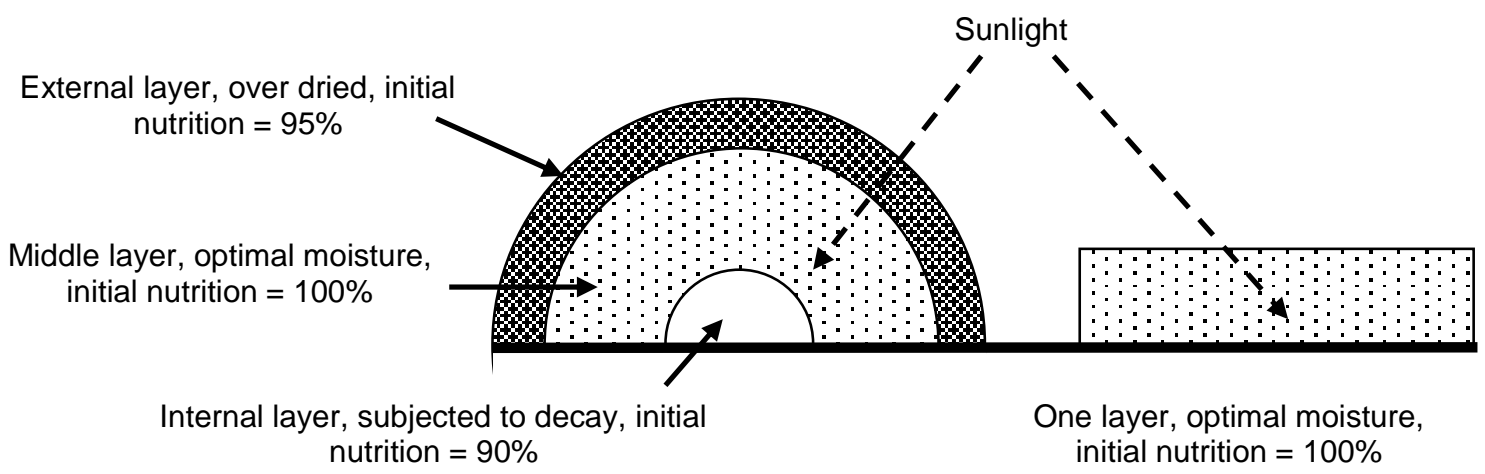

Figure 21. Difference between implemented scheme of drying and existing one.

Source: Author's own elaboration.

As the result of spreading of feed on ground, the daylight goes through the layer of haylage and equally dries it. After the gaining of required moisture (determining by the moisture tester) of the haylage, the haylage is picking up into big roll for further packing. 
Further it is necessary to select one of the rotary tedder, presented on the market of Omsk region. Technical characteristics of analogical tedders are presented in the Table 30.

Table 30. Comparison of technical characteristics of rotary tedders of various marks.

\begin{tabular}{lccc}
\hline & \multicolumn{3}{c}{ Name of machinery } \\
\cline { 2 - 4 } & SIP-Spider 555 & $\begin{array}{c}\text { Tonnuti GTH } \\
\mathbf{5 4 0}\end{array}$ & $\begin{array}{c}\text { Kverneland } \\
\text { Taarup 8076 }\end{array}$ \\
\hline Number of rotors & 4 & 4 & 4 \\
\hline Number of spring pins per rotor, units & 6 & 6 & 6 \\
\hline Productivity, hectar/hour & 5,5 & 5,0 & 5,5 \\
\hline Operational width, $\mathrm{m}$ & 5,3 & 5,8 & 5,5 \\
\hline Transport width, $\mathrm{m}$ & 2,95 & 2,9 & 2,9 \\
\hline Transport height, $\mathrm{m}$ & 2,7 & 1,2 & 2,7 \\
\hline Width, $\mathrm{m}$ & 5,72 & 5,5 & 5,72 \\
\hline Mass, kg & 475 & 445 & $\mathbf{4 7 5}$ \\
\hline Required tractor capacity, $\mathrm{kWt}$ & 15 & 15 & 15 \\
\hline Rotations (rot/minute) & $450-540$ & 540 & $450-540$ \\
\hline Country producer & Slovenia & Italy & Germany \\
\hline Price, thousand rubles & $\mathbf{4 0 9} \mathbf{2 0 0}$ & 421600 & 877300 \\
\hline
\end{tabular}

Source: SIP.si, (2017); Tonnuti.it, (2017); Krone.ru, (2017).

Based on the data presented in the Table 30, was made the decision to purchase the rotary tedder SIP-Spider 555. This type of rotary tedder was chosen based on main indicators, such as productivity and price, because the others parameters are almost similar. Appearance of SIPSpider 555 is presented on the Figure 22.

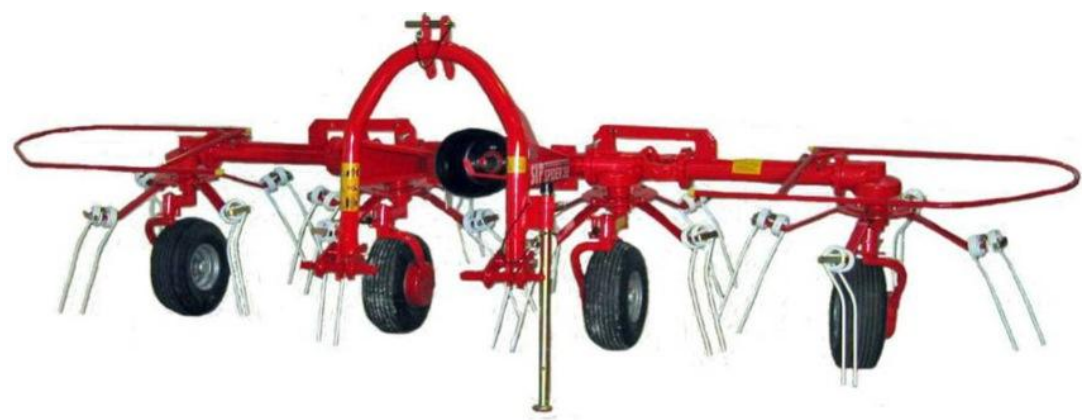

Figure 22. Rotary tedder SIP-Spider 555.

Source: SIP.si, (2017).

Bales forming, wrapping

Second implemented stage - picking up of a bale, compression, forming into cylindrical form, wrapping with the grid. Operating scheme of chamber baler is simple: chamber baler aggregated with MTZ-82 with the special pins is picking up the rolled haylage and pit it into the barrel, where it's compressing and getting the cylindrical form. Further, the bale is wrapping by the plastic grid, and unloading to the field. Example of this bale is presented on the Figure 23. 


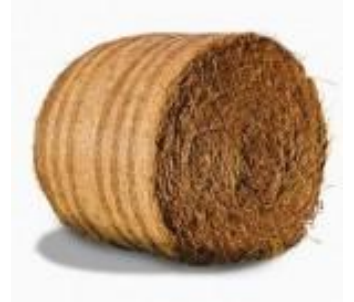

Figure 23. Haylage bale wrapped by the grid.

Source: Agrovesti.net, (2016).

Further it is necessary to select one of the chamber baler, presented on the market of Omsk region. Technical characteristics of analogical chamber balers are presented in the Table 31.

Table 31. Comparison of technical characteristics of chamber baler of various marks.

\begin{tabular}{lccc}
\hline \multirow{2}{*}{ Parameter } & \multicolumn{3}{c}{ Name of machinery } \\
\cline { 2 - 4 } & Metal-Fach Z562 & $\begin{array}{c}\text { Tonutti Wolagri } \\
\text { R10/2000 Super }\end{array}$ & $\begin{array}{c}\text { Krone Comprima CF } \\
155 X C\end{array}$ \\
\hline Dimensions of bale, mm & $1200 \times 1200$ & $1200 \times 1200$ & $1200 \times 1200$ \\
\hline Productivity, units/hour & $20-30$ & $20-30$ & $20-30$ \\
\hline Bale mass, kg (moisture 50\%) & 450 & 450 & 450 \\
\hline Consumed capacity, kWt & from 25 & 33,45 & from 25 \\
\hline Width of baler, mm & 1800 & 1850 & 1800 \\
\hline Length, mm & 3700 & 4040 & 2400 \\
\hline Width operational, mm & 2470 & 2430 & 2200 \\
\hline Height, mm & 2200 & 2050 & 2200 \\
\hline Mass, kg & 2200 & 2160 & Germany \\
\hline Country producer & Poland & Italy & 930000 \\
\hline Price, thousand rubles & $\mathbf{8 8 6 ~ 6 0 0}$ & 1326800 & \\
\hline
\end{tabular}

Source: MetalFach.com, (2017); Tonnuti.it, (2017); Krone.ru, (2017).

Based on the data presented in the Table 31, was made the decision to purchase the chamber baler Metal-Fach Z562. This type of chamber baler was chosen based on main indicators, such as productivity and price, because the others parameters are almost similar. Appearance of Metal-Fach Z562 is presented on the Figure 24.

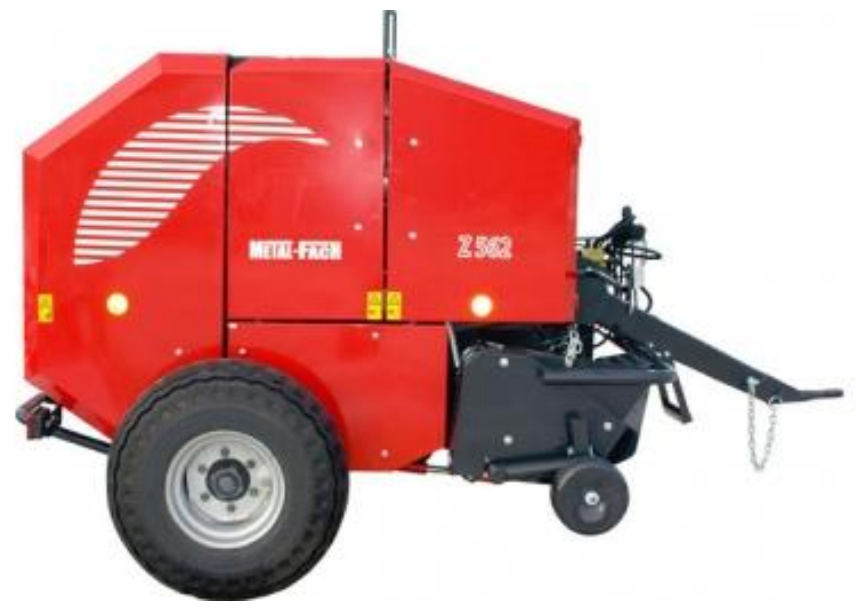

Figure 24. Chamber baler Metal-Fach Z562.

Source: MetalFach.com, (2017). 


\section{Packing of bales, uploading/unloading}

Third and forth implemented stages - picking up of wrapped bale, packing of it into the agrostretch, unloading on the field, picking up of bales and uploading to the tractor's truck, unloading of the storehouse by the bale grabber.

Further it is necessary to select one of the bale wrapper presented on the market of Omsk region. Technical characteristics of analogical bale wrappers are presented in the Table 32.

Table 32. Comparison of technical characteristics of bale wrappers of various marks.

\begin{tabular}{|c|c|c|c|}
\hline \multirow{2}{*}{ Parameter } & \multicolumn{3}{|c|}{ Name of machinery } \\
\hline & Sipma OS 7510 & $\mathrm{OP}-1$ «BAM» & Metal-Fach Z577 \\
\hline Weight of a bale, tons & Up to 1,00 & Up to 1,00 & Up to 1,00 \\
\hline Width of a film, $\mathrm{m}$ & $0,50-0,75$ & $0,50-0,75$ & $0,50-0,75$ \\
\hline Length, $\mathrm{m}$ & 2,59 & 2,20 & 2,30 \\
\hline Width, m & 1,94 & 1,50 & 1,70 \\
\hline Height, m & 2,06 & 1,60 & 1,80 \\
\hline Mass, $\mathrm{t}$ & 0,78 & 0,42 & 0,5 \\
\hline Diameter of a bale, $\mathrm{m}$ & $1,20-1,30$ & $1,20-1,60$ & $1,20-1,30$ \\
\hline Required capacity, h.p. & 30 & 14 & 25 \\
\hline Productivity of bales, units/hour & 40 & 33 & 36 \\
\hline Country producer & Poland & Belarus & Poland \\
\hline Price, thousand rubles & 328600 & 336660 & 568540 \\
\hline
\end{tabular}

Source: Sipma.ru, (2017); Bobruiskagromach.com, (2017); MetalFach.com, (2017).

Based on the data presented in the Table 32, was made the decision to purchase the bale wrapper Sipma OS 7510. This type of bale wrapper was chosen based on main indicators, such as productivity and price, because the others parameters are almost similar. Appearance of packed bale and the process of packing, as well as appearance of Sipma OS 7510 is presented on the figure 25 .

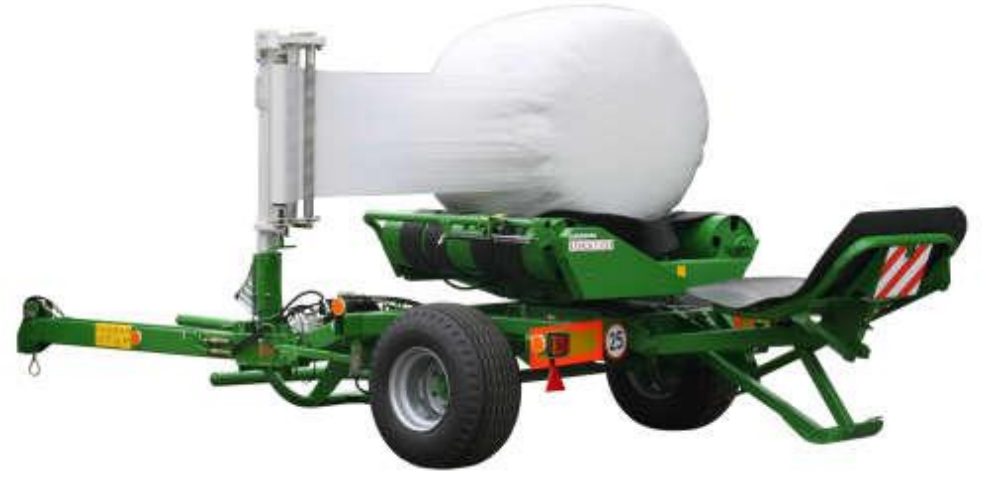

Figure 25. Bale wrapper Sipma OS 7510.

Source: Sipma.ru, (2017).

When choosing of front loader, was made the decision to purchase PSN-1 with bale grabber ZR-1 "Bobruiskagromach", because this kind of machinery is only one presented on the market of Omsk region. The cost of bale grabber with front loader is 399900 and 203360 thousand rubles, 
accordingly. Country producer - Belarus. Appearance of PSN-1 with bale grabber ZR-1 is presented on the picture 26 .

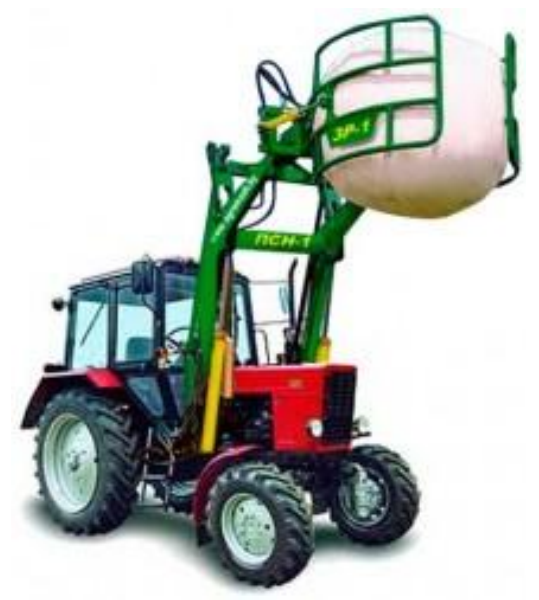

Figure 26. Front loader PSN-1 with bale grabber ZR-1.

Source: Bobruiskagromach.com, (2017).

Summarizing of all mentioned above, we can conclude that after the implementation of all proposed types of agricultural machinery, the company will have complete (according to modern standards) and complete process of harvesting. Advantage of renewable feeds obtained against old ones is its quality, namely: optimal moisture of haylage, absence of any harmful substances in packed product, preserving of nutrition during a long time. Total amount of purchasing machinery is the following:

$$
409200+886600+328600+399900+203360=2227660 \text { rubles. }
$$

Economic efficiency of implementation of this type will be presented in the next chapter.

\subsection{Economic evaluation of implemented measures for increasing of economic sustainability in JSC "Novoazovskoe" of Omsk region}

Considering the level of innovative development of JSC "Novoazovskoe", specific of production activity, financial and economic parameters of enterprise, sizes and structure of production, it is necessary to make an economic estimation of proposed measures.

It is necessary to start the calculation of economic efficiency from providing the data of amount of produced haylage and its consumption during the year. Data are presented in the Table 33. 
Table 33. Production and consumption of a haylage in JSC "Novoazovskoe" in 2013-2015.

\begin{tabular}{|c|c|c|c|c|c|c|c|c|c|}
\hline \multirow{2}{*}{ Parameters, 100 kg } & \multicolumn{3}{|c|}{ Year } & \multicolumn{2}{|c|}{2014 to 2013} & \multicolumn{2}{|c|}{2015 to 2014} & \multicolumn{2}{|c|}{2015 to 2013} \\
\hline & 2013 & 2014 & 2015 & Amount & In \% & Amount & $\ln \%$ & Amount & $\ln \%$ \\
\hline Begin of a year & 88974 & 80378 & 78459 & -8596 & $90,3 \%$ & -1919 & $97,6 \%$ & -10515 & $88,2 \%$ \\
\hline Produced & 123210 & 109727 & 117403 & -13483 & $89,1 \%$ & 7676 & $107,0 \%$ & -5807 & $95,3 \%$ \\
\hline Consumed & 131806 & 111646 & 108552 & -20160 & $84,7 \%$ & -3094 & $97,2 \%$ & -23254 & $82,4 \%$ \\
\hline incl. to animals & 129710 & 110017 & 105452 & -19693 & $84,8 \%$ & -4565 & $95,9 \%$ & -24258 & $81,3 \%$ \\
\hline End of a year & 80378 & 78459 & 87310 & -1919 & $97,6 \%$ & 8851 & $111,3 \%$ & 6932 & $108,6 \%$ \\
\hline
\end{tabular}

Source: Author's own elaboration based on bookkeeping statement of JSC "Novoazovskoe" for 2013-2015.

As we can see from the Table 33, the amount of consumed haylage decreased from year to year: from 2013 to 2015 decreased from 129710 centners to 105452 centners accordingly.

Based on the Table 33 and information from the chapter 4.2 we can calculate remains of good haylage in the total mass of harvested haylage, and specify the losses due to impact of each negative factor. Data for the analysis of lost haylage were obtained from the Chief agronomist according to his survey for other 10 years.

Table 34. Volume of lost haylage during harvesting, storage and use for 2013-2015.

\begin{tabular}{|c|c|c|c|c|}
\hline Parameter & Year & 2013 & 2014 & 2015 \\
\hline \multicolumn{5}{|c|}{ Loss of quantity } \\
\hline Initially harvested mass, centners & & 127021 & 113121 & 121034 \\
\hline Loss of quantity & $\begin{array}{c}\text { In average } \\
\text { in } \%\end{array}$ & In $100 \mathrm{~kg}$ & In $100 \mathrm{~kg}$ & $\ln 100 \mathrm{~kg}$ \\
\hline On harvesting & $3 \%$ & 3811 & 3394 & 3631 \\
\hline Harvested, centners & & 123210 & 109727 & 117403 \\
\hline Loss due to extreme weather condition & $1 \%$ & 1232 & 1097 & 1174 \\
\hline Loss due to pests and rodents & $2 \%$ & 2464 & 2195 & 2348 \\
\hline Loss due to pathogenic microorganisms & $11 \%$ & 13553 & 12070 & 12914 \\
\hline Total losses, centners & & 21060 & 18755 & 20067 \\
\hline Total losses, \% & & $17 \%$ & $17 \%$ & $17 \%$ \\
\hline Remain, centners & & 105961 & 94365 & 100967 \\
\hline \multicolumn{5}{|c|}{ Loss of quality } \\
\hline Harvested, centners & & 123210 & 109727 & 117403 \\
\hline Loss of quality & $\begin{array}{c}\text { In average } \\
\text { in } \%\end{array}$ & In $100 \mathrm{~kg}$ & In $100 \mathrm{~kg}$ & In $100 \mathrm{~kg}$ \\
\hline On harvesting & $15 \%$ & 18482 & 16459 & 17610 \\
\hline Harvested good haylage, centners & & 104729 & 93268 & 99793 \\
\hline Loss due to air, moisture, light & $10 \%$ & 10473 & 9327 & 9979 \\
\hline Loss due to extreme weather condition & $5 \%$ & 5236 & 4663 & 4990 \\
\hline Loss due to pests and rodents & $5 \%$ & 5236 & 4663 & 4990 \\
\hline Loss due to pathogenic microorganisms & $20 \%$ & 20946 & 18654 & 19959 \\
\hline Total losses of good haylage, centners & & 60373 & 53766 & 57527 \\
\hline Total losses of good haylage, $\%$ & & $49 \%$ & $49 \%$ & $49 \%$ \\
\hline Remains of good haylage, centners & & 62837 & 55961 & 59876 \\
\hline \multicolumn{5}{|c|}{ Volume of good haylage in total mass, $\%$} \\
\hline Good haylage in remains & & $59 \%$ & $59 \%$ & $59 \%$ \\
\hline
\end{tabular}

Source: Author's own elaboration based on bookkeeping statement of JSC "Novoazovskoe" for 2013-2015. 
Based on the Table 34, we can say that during the harvesting the haylage losses its quality on $15 \%$ and quantity on $3 \%$. Also, additionally, when storage and use the haylage losses its quality on $40 \%$ and quantity on $14 \%$.

After the implementation of a new system of harvesting, the loss of quantity and quality on the stage of harvest will be $1 \%$ and $5 \%$ of total mass of haylage, accordingly. When storage and use of the haylage it will loss $6 \%$ of quantity and $13 \%$ of quality. Based on that statement, we can calculate the volume of good haylage in total mass of harvested haylage. Calculations will be performed based on the data of 2013-2015 years for giving the example of what could be, if existing harvesting system would be replaced by the modern one. Results are in the Table 35.

Table 35. Proposed results after implementation of new harvesting system in 2013-2015.

\begin{tabular}{|c|c|c|c|c|}
\hline & Year & 2013 & 2014 & 2015 \\
\hline \multicolumn{5}{|c|}{ Loss of quantity } \\
\hline Initially harvested mass, centners & & 127021 & 113121 & 121034 \\
\hline Loss of quantity & $\begin{array}{c}\text { In average } \\
\text { in \% }\end{array}$ & In $100 \mathrm{~kg}$ & In 100 kg & In $100 \mathrm{~kg}$ \\
\hline On harvesting & $1 \%$ & 1270 & 1131 & 1210 \\
\hline Harvested, centners & & 125750 & 111989 & 119824 \\
\hline Loss due to extreme weather condition & $0 \%$ & 0 & 0 & 0 \\
\hline Loss due to pests and rodents & $1 \%$ & 1258 & 1120 & 1198 \\
\hline Loss due to pathogenic microorganisms & $5 \%$ & 6288 & 5599 & 5991 \\
\hline Total losses, centners & & 8815 & 7851 & 8400 \\
\hline Total losses, \% & & $7 \%$ & $7 \%$ & $7 \%$ \\
\hline Remain, centners & & 116935 & 104139 & 111424 \\
\hline \multicolumn{5}{|c|}{ Loss of quality } \\
\hline Harvested, centners & & 127021 & 113121 & 121034 \\
\hline Loss of quality & $\begin{array}{c}\text { In average } \\
\text { in } \%\end{array}$ & In $100 \mathrm{~kg}$ & In 100 kg & In $100 \mathrm{~kg}$ \\
\hline On harvesting & $5 \%$ & 6288 & 5599 & 5991 \\
\hline Harvested good haylage, centners & & 119463 & 106390 & 113832 \\
\hline Loss due to air, moisture, light & $3 \%$ & 3584 & 3192 & 3415 \\
\hline Loss due to extreme weather condition & $1 \%$ & 1195 & 1064 & 1138 \\
\hline Loss due to pests and rodents & $2 \%$ & 2389 & 2128 & 2277 \\
\hline Loss due to pathogenic microorganisms & $7 \%$ & 8362 & 7447 & 7968 \\
\hline Total losses of good haylage, centners & & 21818 & 19430 & 20789 \\
\hline Total losses of good haylage, $\%$ & & $17 \%$ & $17 \%$ & $17 \%$ \\
\hline Remains of good haylage, centners & & 103933 & 92559 & 99034 \\
\hline \multicolumn{5}{|c|}{ Volume of good haylage in total mass, $\%$} \\
\hline Good haylage in remains & & $88 \%$ & $88 \%$ & $88 \%$ \\
\hline
\end{tabular}

Source: Author's own elaboration based on bookkeeping statement of JSC "Novoazovskoe" for 2013-2015;

Zootehnikoff.ru (2014)

As we can see from the Table 35, there is $88 \%$ of good haylage as remain in total mass of haylage.

So, based on that information, we can calculate the denied gross profit, received from selling of surplus of haylage received from the difference of required volume of haylage: from Item "Remain 
of good haylage" in the Table 35 we subtract item "Remains of good haylage" in the Table 34 . Results are in the Table 36.

Table 36. Financial results from selling the denied surplus.

\begin{tabular}{lrrr}
\hline \multicolumn{1}{c}{ Parameter } & $\mathbf{2 0 1 3}$ & $\mathbf{2 0 1 4}$ & $\mathbf{2 0 1 5}$ \\
\hline Remain of good haylage in new system, centners & 103933 & 92559 & 99034 \\
\hline Remain of good haylage in old system, centners & 62837 & 55961 & 59876 \\
\hline Haylage for sale, centners & 41096 & 36598 & 39159 \\
\hline Price per centners, rubles & 450 & 500 & 550 \\
\hline Proposed revenues, rubles & 18493027 & 18299240 & 21537308 \\
\hline$\quad$ Accumulated proposed revenues, rubles & 18493027 & 36792267 & 58329575 \\
\hline Cost of haylage, rubles/centner & 104,72 & 183,90 & 132,34 \\
\hline Total cost of haylage, rubles & 4303533 & 6730460 & 5182268 \\
\hline$\quad$ Accumulated cost, rubles & 4303533 & 11033993 & 16216261 \\
\hline Proposed gross profit, rubles & $\mathbf{1 4 1 8 9 4 9 4}$ & $\mathbf{1 1 5 6 8 7 7 9}$ & $\mathbf{1 6 3 5 5 0 4 0}$ \\
\hline \multicolumn{1}{c}{ Accumulated proposed gross profit, rubles } & 14189494 & 25758274 & 42113314 \\
\hline
\end{tabular}

Source: Author's own elaboration based on bookkeeping statement of JSC "Novoazovskoe" for 2013-2015.

As we can see from the Table 36, after implementation of the new harvesting system, accumulated proposed gross profit by the end of 2015 could be more than 42 million rubles (Flagma, 2017). That means that JSC "Novoazovskoe" denied more than 42 million rubles of additional potential gross profit, because didn't implement modern harvesting system. This result can say that new system of harvesting is reasonable for implementation.

Further, it's necessary to summarize all data to see the final results of new harvesting system implementation. For the based year will be taken the year 2015. Initial expenditures for purchasing of new machineries will be made in the beginning of next year (January-February), so the results of new harvesting system implementation will be obtaining already in the end of harvesting season and year 2016. Calculation will be given for 5 years. Results are in the Table 37.

Table 37. Initial expenditures and financial results of new harvesting system implementation.

\begin{tabular}{|c|c|c|c|c|c|c|}
\hline Parameter & 2015 & 2016 & 2017 & 2018 & 2019 & 2020 \\
\hline \multicolumn{7}{|l|}{ Haylage for sale } \\
\hline Suplus, centers & 0 & 39159 & 39159 & 39159 & 39159 & 39159 \\
\hline Haylage for sale of remains, $\%$ & 0 & $20 \%$ & $30 \%$ & $40 \%$ & $50 \%$ & $60 \%$ \\
\hline Haylage for sale of remains, centners & 0 & 7832 & 11748 & 15663 & 19579 & 23495 \\
\hline \multicolumn{7}{|l|}{ Costs and revenues } \\
\hline Initial expenditures on machinery, rubles & 0 & 2227660 & 0 & 0 & 0 & 0 \\
\hline Cost of agrostretch, rubles & 0 & 100000 & 100000 & 100000 & 100000 & 100000 \\
\hline Cost of use and maintenance, rubles & 0 & 0 & 12000 & 12000 & 12000 & 12000 \\
\hline Cost of haylage, rubles/centner & 132 & 132 & 132 & 132 & 132 & 132 \\
\hline Total cost of haylage, rubles & 0 & 1036454 & 1554680 & 2072907 & 2591134 & 3109361 \\
\hline Accumulated cost, rubles & 0 & 1036454 & 2591134 & 4664041 & 7255175 & 10364536 \\
\hline Price of haylage, rubles/centner & 550 & 550 & 550 & 550 & 550 & 550 \\
\hline Revenues, rubles & 0 & 4307462 & 6461192 & 8614923 & 10768654 & 12922385 \\
\hline Accumulated revenues & 0 & 4307462 & 10768654 & 19383577 & 30152231 & 43074616 \\
\hline Total gross profit, rubles & 0 & 943348 & 4794512 & 6430016 & 8065520 & 9701024 \\
\hline Accumulated total gross profit, rubles & 0 & 943348 & 5737860 & 12167876 & 20233396 & 29934420 \\
\hline
\end{tabular}

Source: Author's own elaboration based on bookkeeping statement of JSC "Novoazovskoe" for 2013-2015. 
As we can see from the Table 37, JSC "Novoazovskoe" will generate profit from selling of remains of haylage. Total accumulated gross profit for 5 years is more than $29 \mathrm{mln}$ rubles. This fact means that it is much more profitable and reasonable for the company to implement the proposed harvesting system, than to use the existing one.

Summarizing all the above, we can assert, that development of an enterprise in the branch of haylage selling is one of the most prospective directions. Reason for that - the lack of enterprises in Omsk region, specializing on haylage production. Results of this lack is that there are no strong competitors on the market, like on the grain or milk markets. Because of JSC "Novoazovskoe" is one of the leaders in milk production, company should implement the production of new feeds, or improving the existing one. As the result of implementation of new feeds, company can take its niche on new market of agricultural production, enter to this market with the production meets to modern requirements of quality of haylage and conditions of storage. Further, for JSC "Novoazovskoe" is possible to enter on the marker of Siberia, Russia and Foreign countries. 


\section{Conclusions, Limitations and Future Research Lines}

Based on implemented analysis of the definition of "Economic sustainability of enterprise" is possible to conclude, that it is complicated meaning, which includes a lot of components, such as: production and technical, commercial, organizational, innovation, financial, social, industrial and regional sustainability. One of the main feature of economic sustainability increasing in agricultural enterprise is diversification of crops (including livestock), harvesting and cultural practices to enhance the biological and economic stability of the farm.

By making the analysis of activity of JSC "Novoazovskoe" was inspected the following information:

- company's balance sheet increased from 319543 thousand rubles to 368460 thousand rubles from 2013 to 2015, accordingly;

- company's net profit decreased from 32167 thousand rubles to 19787 thousand rubles from 2013 to 2015 , accordingly;

- company's total square of agricultural lands increased on 82 hectares from 11118 hectares in 2013 to 11200 hectares in 2015, where $100 \%$ of it is arable;

- company's total number of means of production decreased from 339 units in 2013 to 207 units in 2015, but in monetary term increased from 91177 thousand rubles in 2013 to 100086 thousand rubles in 2015;

- number of cattle decreased on 8 units from 2668 units in 2013 to 2660 units in 2015, and in monetary term increased from 88060 thousand rubles in 2013 to 104335 thousand rubles in 2015. Number of milking cows was the same for 2013-2015 and equal to 1023 , and in monetary term increased on 10281 thousand rubles from 47821 in 2013 to 58102 thousand rubles in 2015;

- number of employees decreased from 294 to 235 units from 2013 to 2015 accordingly, and in monetary term salary increased from 68924 thousand rubles in 2013 to 73336 thousand rubles in 2015;

— total volume of milk produced increased from 48707 centners in 2013 to 54272 centners in 2015, and in monetary terms increased from 87670 thousand rubles in 2013 to 199495 thousand rubles in 2015.

Based on the implemented SWOT Analysis was examined that the weaknesses include: Low quality of harvested feeds because of big loss of harvested feeds as the result of improper and oldstyle process of harvesting and storage of them, unacceptable conditions of storage of haylage, and its loss of more than half of nutrition value, lack of modern equipment for feed harvesting, storage and delivery.

The research hypotheses that were considered in $2^{\text {nd }}$ chapter, were implemented:

- after implementation of a new haylage harvesting system, the company increased the volume of a good haylage in total harvested mass of haylage up to $80 \%$ (achieved $83 \%$ ); 
— implementation of the new haylage harvesting system can bring additional revenues in total income of a company.

For improving that problem it is proposed the implementation of new haylage harvesting system, what includes changing the harvesting process and purchasing of new required agricultural machineries. These machineries include: rotary tedder, chamber baler, bale wrapper, front loader. Total cost of purchasing agricultural machineries is 2227660 rubles. After implementation of modern haylage harvesting system, the quality of harvested haylage increase up to $83 \%$ of good haylage in total mass, and $88 \%$ in remains.

After realization of a surplus of haylage, JSC "Novoazovskoe" will receive additionally 29934420 rubles of gross profit, what means that proposed system is reasonable for implementation.

For the future researches can be chosen the following themes, related to the topic of this Master thesis:

- implementation of new kinds of crop in plant growing branch, for increasing the total yield production of plant growing;

— implementation of new milking parlor system, feeding system, what will lead to increase of milk production;

- making of new branch of activity such as international sales what can lead to diversifying of business;

- implementation of recycling technologies, what can help to recycle dung into bio-fuel and fertilizers, and to minimize company's dependence from electro generating companies. 


\section{References}

Agrovesti.net. (2017). Technology of harvesting and storage of a haylage. [On-line]. Available: https://agrovesti.net/kormoproizvodstvo/technologiya_zagotovki_i_chraneniya_senazha.html, Access date: 10.06.2017.

Anisimov, Y. (2006). Management of sustainable development of a company based on innovations and entrepreneurship. Voronezh:VSTA.

Bakanova, M. (2008). Analysis of main factors of economic sustainability of modern enterprise. Journal "Vestnik MSPU". 108-111.

Bobruiskagromach.com. (2017).[On-line]. Available: http://bobruiskagromach.com/, Access date: 10.06.2017.

Bodrov, O. (2008). Economic freedom and sustainability of enterprise. Kazan: Taglimat.

Bryantseva, I. (2007). Economic sustainability of enterprise: entity, assessment, management. Khabarovsk: KSTU.

Bulatov, A. (2007). Economics: study book. Moscow: Yurist.

Feenstra, G., Ingels, C., \& Campbell, D. (2016). What is sustainable agriculture? [On-line]. Available: http://asi.ucdavis.edu/programs/sarep/about/what-is-sustainable-agriculture/\#plantproduction-practices, Access date: 10.06.2017.

Flagma.ru. (2017). Haylage for feed. [On-line]. Available: http://kommunarlenin.flagma.ru/senazhkorm-provyalennyh-trav-03038356.html, Access date: 10.06.2017.

Folomjev, A. (1995). Sustainability of enterprise on the market. Moscow.

Goldstein, G. (2003). Basics of management: study book. $2^{\text {nd }}$ edition. Taganrog: TRTU.

Golobokova, G. (2008). Economic stability: study book. Moscow: Infra-M.

Golovko, E. (2013). Definitions of sustainable system. Journal "Young scientist”,283-283

Investopedia.com (2017). Cost-Volume-Profit analysis. [On-line]. Available:

http://www.investopedia.com/terms/c/cost-volume-profit-analysis.asp, Access date: 10.06.2017.

Kamaev, V. (2008). Economics and business (theory and practise of entrepreneurship). Moscow: Ekonomika.

Koryakov, A.(2012). Economic sustainability of enterprise development: classification and key factors. Journal "Modern Science: actual problems of theory and practise". 5-10.

Kovalev, A. (2010). Introduction in financial management: study book. Moscow: Finance and statistics.

Krestniaksky dom. (2015).Haylage in package. [On-line]. Available:

http://www.kd59.ru/tehnologiya-senazh-v-upakovke, Access date: 10.06.2017. 
Krone.ru. (2017). [On-line]. Available: http://www.krone-rus.ru/espa\%C3\%B1ol/glavnaja/, Access date: 10.06.2017.

Kuzmenko, O., \& Gritcenko, E. (2016). Economic entity of sustainability of agriculture production. Journal "Scientific and methodological electronic journal "Koncept", 35-38.

Labocky, I. (2013). Feeds from a hose. Journal "Belorus agriculture", 124-129.

Laibert, T. (2011). Economic sustainability: entity, content and factors. Ufa: USSTU.

Lakshina, O., \& Chekmareva, E. (2009). Analysis of financial stability: practice and methodology. Journal "Money and credit", 24-29.

LBR Agromarket. (2017). Haylage in package - make the most nutritious feed. [On-line]. Available: https://www.lbr.ru/company/events/tehnologija-zagotovki-i-hranenija-senazha-v-upakovke/, Access date: 10.06.2017.

Malinin, I. (2013). What feeds can tell to us. Journal "Agricultural News", 70-73

Marks, K., \& Engels, F. (1984). Capital: Critique of Political Economy. Moscow: Politizdat. MetalFach.com. (2017). [On-line]. Available: http://www.metalfach.com.pl/ru/, Access date: 10.06.2017.

Moles, P., \& Terry, N. (1997). The Handbook of International Financial Terms. Oxford: OUP. Nureev, R. (2001). Economics of development: models of market economy formation. Study book. Moscow: Infra-M.

Omelchenko, I. (2009). Financial and economical stability as the main part of organizational and economic sustainability of enterprise. "Journal of mechanical engineering", 63-67.

OmskPortal.ru (2017). Azovsky German National District [On-line]. Available: http://azov.omskportal.ru/ru/municipal/localAuthList/3-52-201-1/officialsite.html, Access date: 10.06.2017.

Osita, I., Onyebuchi, I., \& Nzekwe, J. (2017). Organization's stability and productivity: the role of SWOT analysis an acronym for strength, weakness, opportunities and threat. International Journal of Innovative and Applied Research, 23-32.

Schaltegger, S., Luedeke-Freund, F., \& Hansen, E. (2012). Business cases for sustainability: the role of business model innovation for corporate sustainability. International Journal of Innovation and Sustainable Development, 95-119.

SIP.si. (2017). [On-line]. Available: http://www.sip.si/rotary-tedders-spider-with-4-rotors, Access date: 10.06.2017.

Sipma.ru. (2017). [On-line]. Available: http://www.sipma.ru/, Access date: 10.06.2017. Tonnuti.it. (2017). [On-line]. Available: http://www.tonutti.it/, Access date: 10.06.2017. 
Ukrprolife.com. (2012). Feeds: haylage, silage. [On-line]. Available:

http://ukrprolife.com.ua/krupnyj-rogatyj-skot-2/korma-silos-senazh/, Access date: 10.06.2017.

Zakharchenko, V. (2009). Economic sustainability of enterprise in transitional economy. Journal "Mashinostroitel", 9-11.

Zootehnikoff.ru. (2014). Haylage. [On-line]. Available: http://www.zootehnikoff.ru/senazh/, Access date: 10.06 .2017 . 